UNITED STATES DEPARTMENT OF THE INTERIOR GEOLOGICAL SURVEY

\title{
GEOLOGY OF THE CERRO SUMMIT QUADRANGLE, MDNTROSE COUNTY, COLORADO
}

by

Robert G. Dickinson

$$
66-24
$$

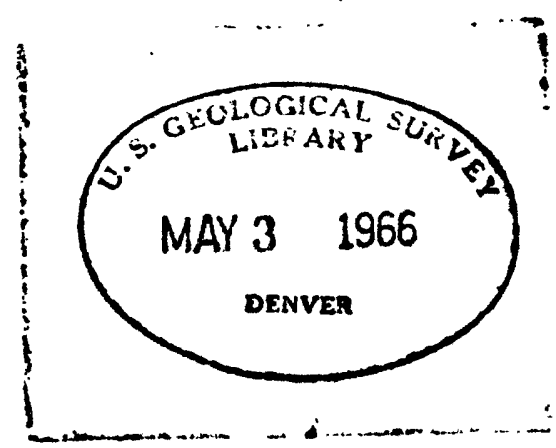

Open-file report 


\section{ACKNOWLEDGMENTS}

The work on which this dissertation is based was done while the author was amployad by the U.S. Geologlcal Survey. The author 1. grateful to the Director of the U.S. Geological Survey for permission to use the information obtained while working for the Survey for this dissertation. The Geological Survey provided office and laboratory space In the Denver Federal Center, Denver, Colorado, in addition to support in the field.

Fossil collections were identified by the following special1sts: W. A. Cobban, G. E. Lewis, C. B. Schultz, L. G. Tanner, Estella B. Leopold, Raymond E. Peck, I. G. Sohn, N. F. Sohl, and Jack A. Wolfe.

H. A. Powers and R. E. Wilcox aided measurably by providing Instruction in the separation and identification of the Pleistocene volcanic ashes. Christel L. Parker, Joseph Haffty, P. R. Barnett, and Harriet Neiman made analyses on glass separated from the volcanic ash. Isotopic age work was done by the Branch of Isotope Geology, U.S. Geological Survey.

The author is particularly grateful to Gerald M. Richmond and Wallace $R$. Hansen for advice given in the field and office. Professor Joseph F. Schreiber, Jr., visited the author In the fleld for three days during the summer of 1963. Roger K. Loper assisted In the field during 1963 and Arthur Hohl assisted during 1964. R. W. O'Donnell as81sted in collection of some fossils in 1963. 
Many ranchers made their lands available for study. Messrs. August and Frederick Bellgardt and Mr. and Mrs. William Allen were particularly helpful. Alvin Strand of Montrose, Colorado, generously made avallable for identification a horse tooth that he collected from the area.

area. 
TABLE OF CONTENTS

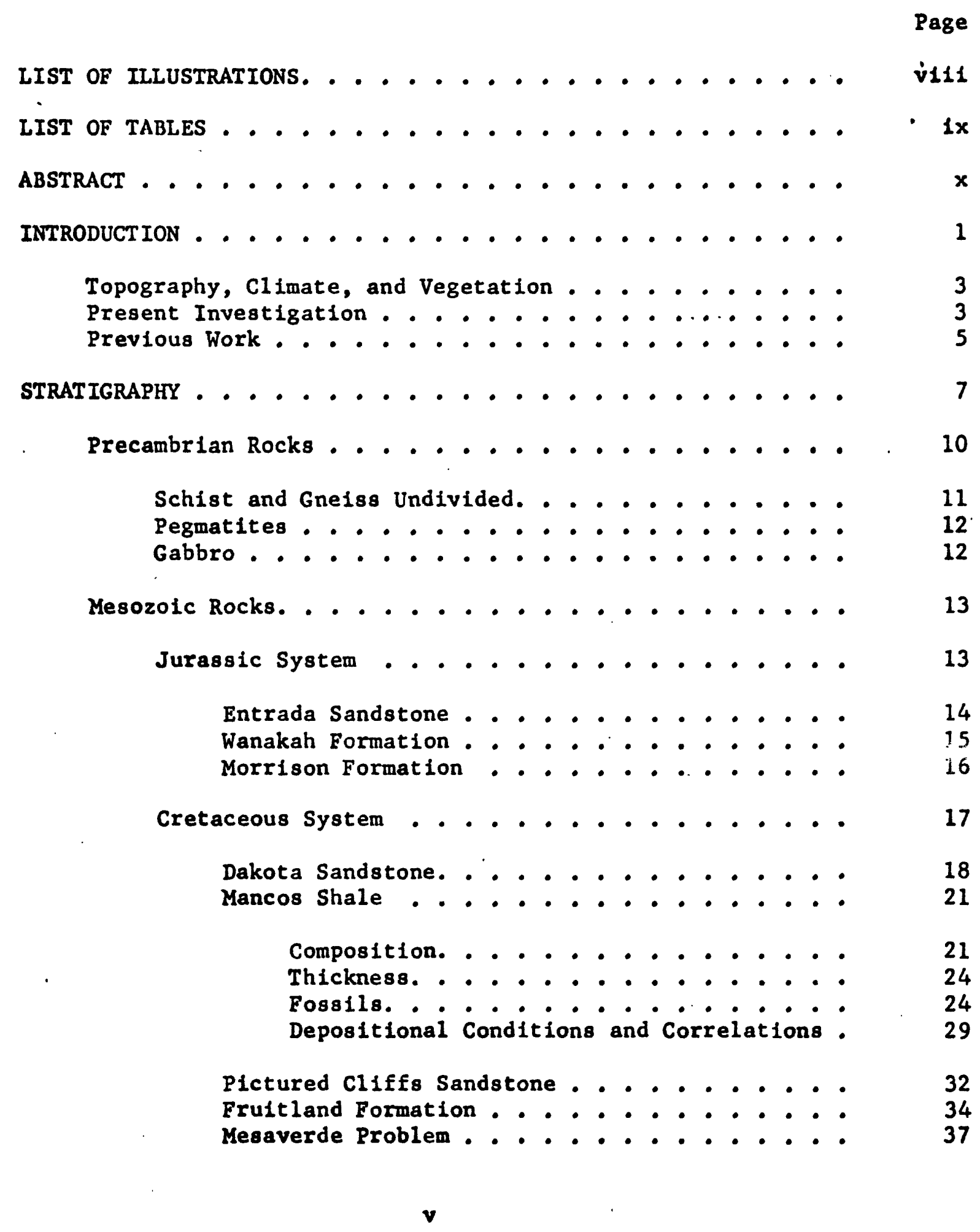


TABLE OF CONTENTS--Continued

Page

STRATIGRAPHY--Continued

Rocks of Late Cretaceous and Tertiary Age In the Adjacent

Cimarron Ridge Area................. 40

Fruitland Formation and Kirtland Shale Undivided . . 42

Upper Cretaceous Volcanic Rocks . . . . . . . 43

Telluride Conglomerate ............ . 46

San Juan Formation... . . . . . . . . . . 47

Potosi Volcanic Group. ................ 48

Tertlary Rocks .. . . . . . . . . . . . 48

Conglomerate on Poverty Mesa . . . . . . . . . . 48

Tertlary or Quaternary Rocks. . . . . . . . . 50

Gravel along Pool Gulch. ............... 50

Older Landslide Deposit on Waterdog Peak . . . . . . 52

Quaternary Rocks. . . . . . . . . . . . . 56

Landslide Deposits . . . . . . . . . . 56

Introduction. . . . . . . . . . . . 56

Description of the Landslide Deposits...... 57

Older Stream Gravel of Shinn Park. . . . . . . . . 67

Valley-fill Deposits of Bostwick-Shinn Park. . . . . 68

Description of the Deposits......... 69

Volcanic Ash in the Valley-f1ll Deposits . . 75

Description of the Volcanic Ash Beds. - 77

Correlations of the Ash Beds........ 81

Correlation and Interpretation of the Valley-fill

Deposits. . . . . . . . . . . . 84

Pediment Deposits. . . . . . . . . . . . . 91

Upper Pediment Deposits . . . . . . . . . 91

Lower Pediment Deposits ............. 93 
TABLE OF CONTENTS--Continued

Page

STRATIGRAPHY--Continued

Quaternary Rocks--Continued

Eollan Deposits. . . . . . . . . . . . . .

Alluvial and Colluvial Deposit8. . . . . . . . 95

STRUCTURE

Reglonal Setting. . . . . . . . . . . . . . .

Faults. . . . . . . . . . . . . . . . . . .

Tectonic Faults. . . . . . . . . . . . . .

Nontectonic Faults . . . . . . . . . . . . .

Folds . . . . . . . . . . . . . . . . . . . .

Age of Deformation. . . . . . . . . . . . . .

GEOLOGIC HISTORY . . . . . . . . . . . . . . . .

Precambrian Era . . . . . . . . . . . . . . . 106

Paleozolc Era ....................... . . . . . 106

Mesozolc Era. . . . . . . . . . . . . . . . 107

Cenozolc Era . . . . . . . . . . . . . . . . . 108

ECONOMIC GEOLOGY • • . . . . . . . . . . . . . . . 112

Coal. ......................... 112

011 and Gas ........................ . . . . 113

clay. .......................... 113

Sand and Gravel ........................ 113

REF ERENCES CITED . . . . . . . . . . . . . . . . 114 
IIST OF ILLUSTRATIONS

Page

Rlate

1. Geologic Map of Cerro Sumit Quadrangle, Montrose

County, Colorado .................. In pocket

F1gure

1. Index Map of Cerro Summit Area, Southwestern Colorado . . . . . . . . . . . . . .

2. Diagramatic Section of the stratigraphic and Structural Relationships along Cimarron Ridge....

3. Stereogram of the Cerro Sumnit Area. . . . . . .

4. Stereogram Showing Extensive Landsiide in Beaton

5. Active Landslides along South Side of Cedar Creek. -

6. Valley-fill Deposits on the North Side of Ellison

7. Generalized Stratigraphic Section of Valley-fill Deposits of Bostwick-Shinn Park at Field Locality 910. . . . . . . . . . . . . . .

8. Soil Zone and Ash Beds $b$ and $c$ in a South-facing H1ghway Cut in the Grizzly Ridge Quadrangle. . . . 
Table

1. Faunal Zones Represented by USGS Mesozolc Fossil

Localities in the Cerro Sumit Quadrangle....

On plate 1

2. Bedrock Formations of Cerro Summit-Cimarron Ridge Area ....................

3. Fossils Found in the Mancos Shale of the Cerro Summit Quadrangle and Adjacent Areas. . . . .

In pocket

4. Tentative Correlation of Pleistocene Valley-fill Deposits of Bostwick-Shinn Park . . . . . . .

5. Comparison of Chemical and Petrographic Properties of Volcanic-ash Beds.............. 


\section{ABSTRACT}

The Cerro Summit quadrangle covers 58 square miles of dissected plateau on the south flank of the Gunnison uplift in southwestern Colorado: It lies east of the Uncompahgre River valley and south of the Black Canyon of the Gunnison River. Rocks dip gently in most of the quadrangle, but they are locally upturned and faulted on the margin of the Gunnison uplift and are intensely deformed in the core of the up11ft. The rocks exposed are of Precambrian, late Mesozoic, and Cenozoic age.

Precambrian rocks include metasedimentary schist and gneiss, granit1c pegmatite, and olivine gabbro. The oldest Mesozoic rocks exposed are continental, fresh-water, and lagoonal deposits in the Late Jurassic Entrada Sandstone, Wanakah Formation, and Morrison Formation. Channel-fill deposits that unconformably overlie the Jurassic rocks are possibly the Burro Canyon Formation of Early Cretaceous age. Uppei Cretaceous rocks include marine and nearshore deposits of the Dakota Sandstone, Mancos Shale, and Pictured Cliffs Sandstone, and the freshand brackish-water sandstone, shale, and coal of the Fruitland Formation. Rocks of Late Cretaceous age that crop out in the adjacent Cimarron Ridge area may also have been deposited in this quadrangle but are now eroded; these rocks Inciude the nonmarine Kirtland Shale and an unnamed volcanic conglomerate and tuff breccia. Nine faunal zones in the Mancos Shale help to establish the correct correlation of units in 
the Upper Cretaceous. The Pictured Cliffs Sandstone, Fruitland Formation, and Kirtland Shale of the Cerro Summit area have been mapped by some geologists as the Mesaverde Formation. Fossils indicate that the rocks are younger than the type Mesaverde. The unnamed volcanic rocks represent major volcanism in nearby areas. A Late Cretaceous (Maestrichtian) age for the volcanism is indicated by palynological evidence and an isotopic age of approximately 66 million years. Middle Tertiary rocks are conglomerate and tuff breccia. Upper Tertlary or lower Quaternary rocks include gravel along Pool Gulch and older landslide debris on Waterdog Peak. Pleistocene and Recent deposits consist of the older stream gravel of Shinn Park, valley-fill deposits of Bostwlck-Shinn Park, and pediment, landslide, eolian, alluvial, and colluvial deposits. Pleistocene valley-fill deposits of Bostwick-Shinn Park were deposited during the Cedar Ridge, or Kansan, to Pinedale or late Wisconsin times. The valley-fill deposits are divided into five units that are separated by strong interglacial or Interstadial soils and that contain three volcanic ash beds. Chemical and petrographic data suggest that the middle ash bed may correlate with the Pearlette Ash Member (late Kansan) of the Sappa Formation in Nebraska. Alluvium on two pediment surfaces seems to be of Sacagawea Ridge or Illinolan age. Landslide deposits, of Plelstocene and Recent age, cover about 85 percent of the quadrangle; most of the deposits were formerly mapped as $t 111$. The name Cerro $T 111$ was abandoned because t111 does not occur in the type area. 
$\times 11$

The dominant tectonic structures are the high-angle Cimarron fault of a few thousand feet displacement and the broad Montrose syncline. Evidence in the Cimarron Ridge area suggests that these structures formed in Late Cretaceous (Maestrichtian) time. Much of the strata near the surface of the quadrangle has been Involved in landsliding that has continued from late Tertiary to the present. 


\section{INTRODUCTION}

The Cerro Summit quadrangle includes an area of about 58 square miles in Montrose County, Colorado (f1g. 1). The quadrangle 1les along the boundary of the Southern Rocky Mountain and Colorado Plateau provInces (Fenneman and Johnson, 1946) and mainly shows geologic features characteristic of the plateau country. The West Elk and San Juan Mountains are about 30 miles to the northeast and south, respectively; the Uncompahgre Plateau is about 25 miles to the west. The north boundary of the quadrangle touches the south edge of the Black Canyon of the Gunnison River and the west boundary lies along the east edge of the Uncompahgre RIver valley. Cerro Summit, near the east-central edge of the quadrangle, is on the divide between the Uncompahgre River and Cimarron Creek.

The quadrangle is about 7 miles east of the town of Montrose, and U.S. Highway 50 crosses the quadrangle east to west over Cerro sumit. State Highway 347, which goes to the Black Canyon of the Gunnison National Monument, joins U.S. 50 near the west border of the quadrangle. Improved and unimproved dirt roads lead from U.S. 50 into most parts of the area. Agriculture is the main industry in the quadrangle. Irrigated farms In Bostwick Park, Shinn Park, and along Cedar Creek produce a varlety of forage crops, and cattle and sheep are pastured on the hills during the summer. A gas station and curlo shop serves the summer tourist trade at the junction of U.S. 50 and State Highway 347. 


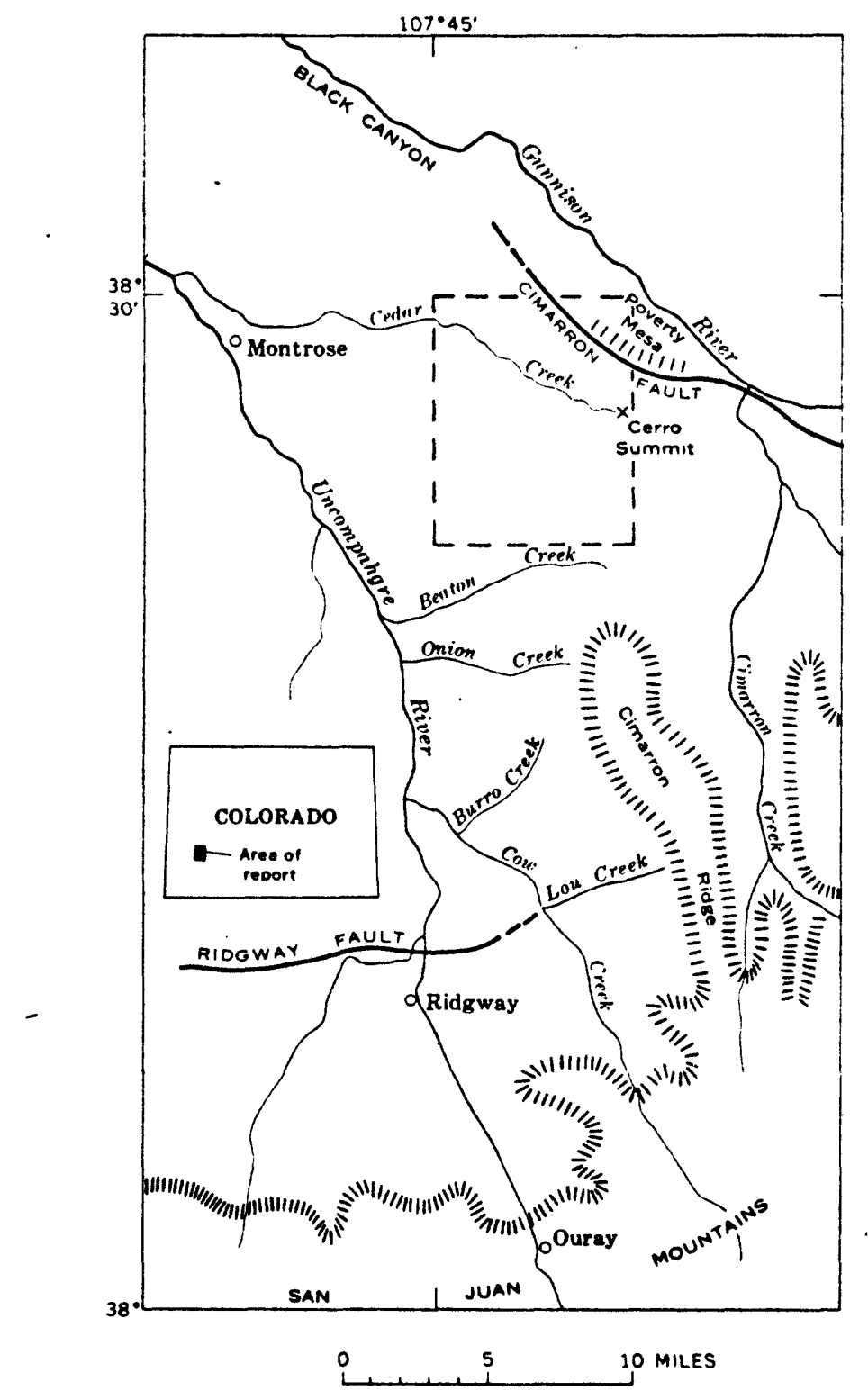

FIGURE 1.--Index map of the Cerro Summit area, southwestern Colorado. Quadrangle boundary shown by a dashed line. 
Topography, Climate, and Vegetation

Altitudes in the Cerro Summit quadrangle range from about 9,400 feet in the northern and southern parts of the area to about 6,470 feet where Cedar Creek leaves the quadrangle on the northwest. Relatively hard metamorphic rocks crop out in the northeast corner of the quadrangle as a high mesa bounded by a steep escarpment on the south. Softer shale and sandstone, which underlie the rest of the quadrangle, have been dissected into steep-sided valleys separated by ridges and irregular-sloping - surfaces. Much of the area that is underlain by shale and sandstone is mantled by landslide debris which has a hummocky, irregular surface.

Bostwick and Shinn Parks in the northwest part of the quadrangle represent a once-continuous stream valley that has been dissected by the headward erosion of Cedar Creek. Upper portions of two pediments which descend into the Uncompahgre River valley are present in the southwestern part of the quadrangle.

The climate varies with altitude: at lower altitudes it is seniarld, supporting a scrub oak-pinon-juniper association; above 9,000 feet It is subhumid, with an aspen and meadow climax. Many of the lower southand west-facing slopes are practically barren of vegetation most of the year.

\section{Present Investigation}

The present investigation of the Cerro Sumit quadrangle was made as part of a program of the U.S. Geological Survey to classify 
withdrawn mineral 1 ands and to add to the geologic atlas of the United States through detalled mappling.

The geology of the quadrangle was mapped in the field on aerial photographs during parts of the summers of 1961-63. The geology was later transferred to the Cerro Summit 1:24,000 topographic base by means of a multiplex plotter. Some of the data used in this report were gathered in the Cimarron RIdge area (f1g. 1), south of the quadrangle, during the summers of 1962-64.

The bedrock of the quadrangle is largely Upper Cretaceous Mancos Shale, but surficial deposits obscure much of the bedrock in the area. Conslderable time and effort were spent searching for fossils in the Nancos in an effort to establish sufficient stratigraphic control so that structure, could be mapped and in order to determine the age and correlation of the overlying Upper Cretaceous coal-bearing beds. Also, In the course of the investigation it became apparent that the Quaternary rocks were worthy of study in their own right. Valley-f111 deposits in the Bostwick-Shinn Park area were found to include an unusually complete section of middle and late Pleistocene sediments. Several burled soil profiles occur in the deposits, along with three separate volcanic ash beds, one of which may be equivalent to the Pearlette Ash Member (1ate Kansan) of the Sappa Formation in Nebraska. The valley-fill deposits were examined in detali, but final interpretation of the deposits must awalt completion of studies being done by the writer on Pleistocene deposits in the Uncompahgre River valley. 
Mapping by the writer in the Cimarron Ridge area, south of the quadrangle, has shown that uplift and volcanlsm occurred in Late Cretaceous time. Some of the Cimarron RIdge data are presented, in preliminary form, to support interpretation of the stratigraphy and structure of the quadranglo.

\section{Previous Work}

Little detalled geologic mapping was done previously in the Cerro Sumit area. The surficial deposits near Cerro Sumit were interpreted as till by Hills (1884, p. 42), and Atwood (1915) gave the deposits the name Cerro Till. Later, Atwood and Mather (1932) presented their interpretation of the physiography and Quaternary geology of the San Juan Mountalns and described at length the surficlal deposits called the Cerro Till as well as other Quaternary deposits.

Hunter (1925) mapped the Precambrian rocks along the Black Canyon of the Gunnison River, which included the northeastern part of the Cerro Sumit quadrangle. Cross and Larsen (1935) show the general bedrock geology on their map.

Varnes (1949) reported on recent landsildes along the north end of Shinn Park. Liang (1952) brlefly described these landslide deposits along with those on Squaw Hill. W. E. Yeend Included the southern part of the Cerro Sumit quadrangle in his study.

1. Yeend, W. E., 1961, Geology of Cimarron Ridge-Cimarron Creek area, San Juan Mountains, Colorado: University of Colorado master's thesis, Boulder, Colorado. 
Wallace R. Hansen of the U.S. Geological Survey has completed. mapping of several quadrangles north and east of the Cerro sumit quadrangle. 


\section{STRATIGRAPHY}

Rocks exposed in the Cerro Sumit quadrangle are of Precambrian, Mesozo1c, Tertiary, and Quaternary age. The principal 11thologic characteristics of the pre-Quaternary rocks are summarized on table 2.

The Precambrian rocks include schist, gneiss, pegmatite, and two small bodies of olivine gabbro. These rocks crop out in the northeast part of the quadrangle but were not mapped in detail. The Mesozolc rocks, which are of Late Jurassic and Cretaceous age, were deposited in both marine and nonmarine environments and include sandstone, limestone, shale, gypsum, and coal. The Jurassic and Cretaceous rocks exposed in the quadrangle are divided into seven formations which are, from oldest to young- , est: the Entrada Sandstone, the Wanakah Formation, and the Morrison Formation of Late Jurassic age; the Dakota Sandstone of Early and Late Cretaceous age; and the Mancos Shale, the Pictured Cliffs Sandstone, and the Fruitland Formation of Late Cretaceous age. Erosional unconformities separate the Entrada, Wanakah, Morrison, and Dakota Formations.

The Tertiary rocks are continental conglomerates with some assoclated tuff breccias. Some unconsolidated surficlal deposits may be as old as Tertiary. The Quaternary deposits are primarily landside deposits but also Include alluvium, colluvium, and eolian deposits. Informal names have been used to designate eight different Tertiary and Quatemary units mapped in the area. The units include gravel along Pool Gulch and older landslides of Pllocene or Pleistocene age; older stream gravel of Shinn 


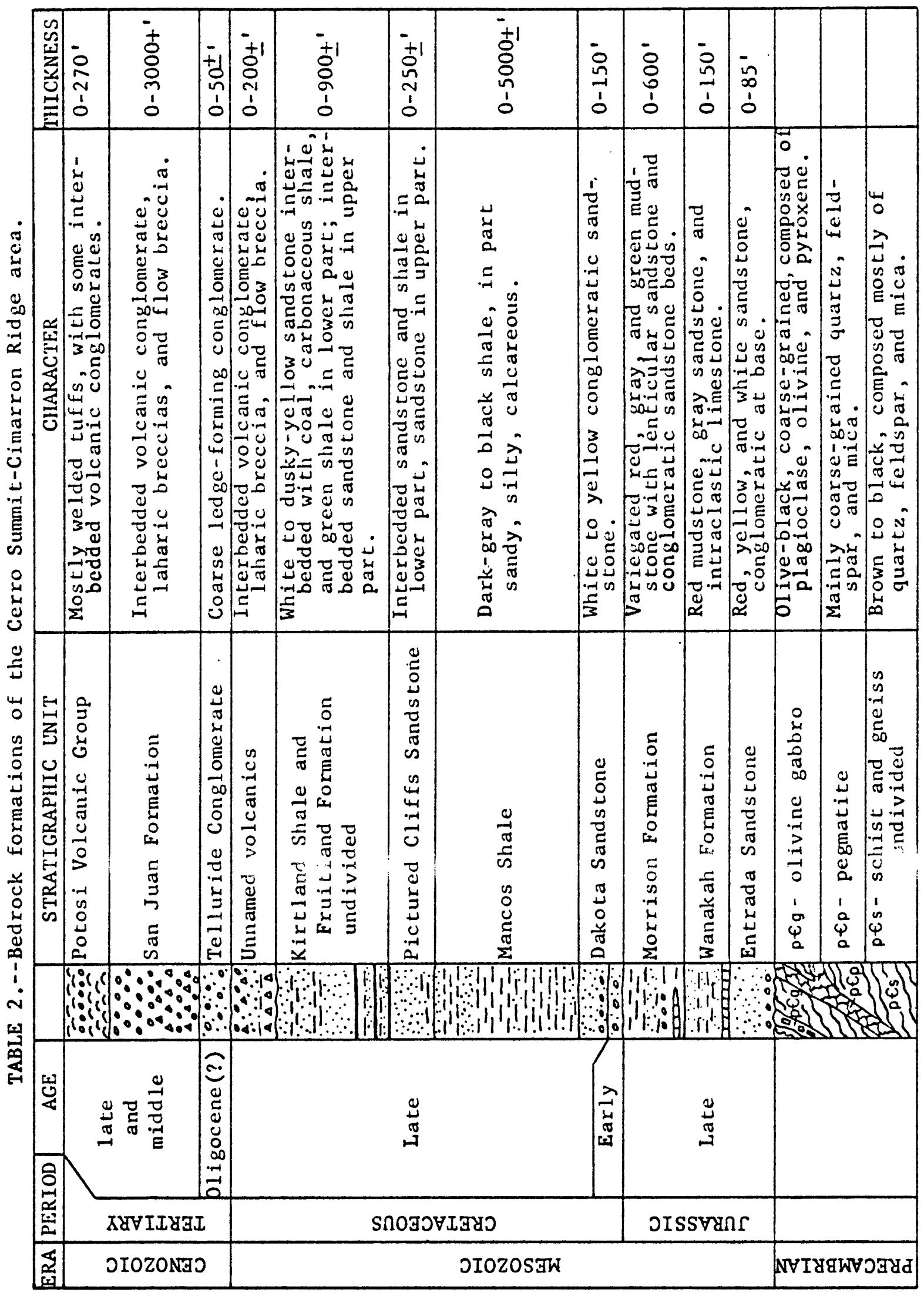


Park, valley-fill deposits of Bostwick-Shinn Park, and pediment deposits of Pleistocene age; and landslide deposits, eolian deposits, and alluvium and colluvium of Plelstocene and Recent age.

The aggregate thickness of the sedimentary rocks exposed in the quadrangle 18 probably about 3,300 feet, with approximately 2,800 feet of the total being Mancos Shale. No deep holes have been drilled in the mapped area. A drill hole about 1 mile north of the northwest corner of the quadrangle penetrated about 1,200 feet of Mancos Shale and about 1,000 feet of older Mesozoic rocks before bottoming in Precambrian rocks. The Jurassic rocks transgress by eastward onlap the eroded surface of the late Paleozoic ancestral Uncompahgre highland. Consequently, older Mesozoic rocks may be present in the subsurface section in the southwestern part of the quadrangle. The combined thlckness of the sedimentary rocks in the southwestern part of the quadrangle is probably between 4,000 and 6,000 feet.

A thlck sequence of Upper Cretaceous and Tertiary rocks that may have covered all or part of the quadrangle at times during the Tertiary crops out in the cliffs along Cimarron Ridge south of the quadrangle. These rocks include the Fruitland and Kirtland Formations undivided and an unnamed unit of volcanic rocks of Late Cretaceous age, the Telluride Conglomerate of 01 igocene(?) age, the San Juan Formation of middle and late Tertlary age, and welded tuffs of the Potosi Volcanic Group of middle and late Tertiary age. The principal lithologic characterlstics of these units are sumarized in table 2. A brief description of these Upper Cretaceous and Tertiary rocks exposed south of the quadrangle is 
given to facilitate discussion of the stratigraphic history and deformation of the Cerro Sumit quadrangle.

The bedrock of the quadrangle is poorly exposed, being mostly covered by landslide and colluvial debris. The Mancos Shale, which underlies more than 90 percent of the quadrangle, is extremely susceptible to mass wasting and is only exposed on south- or west-facing slopes or In landslide scarps. The other Mesozolc formations crop out as small patches through the landslide and colluvium. The surficial deposits are also usually poorly exposed, although in the BostwickShinn Park area valley-fill deposits are well exposed.

Fossils were collected from the Mancos Shale, the Pictured Cliffs Sandstone, the Fruitland Formation, and the valley-fill deposits of Bostwick-Shinn Park. The collections from the Mancos or Mancos-derived landslide debris include 67 species from 44 localities. Nine of the reglonal faunal zones (table 1 on p1. 1) are represented in the collection. The fossil collections from the other rock units are meager and have limited value.

Precambrian Rocks

Precambrian rocks crop out in the northeastern corner of the quadrangle as a high partly dissected mesa that is bounded on the south by the Cimarron fault. The rocks are schist and gneiss that have been Intruded by numerous pegmatites and by two small olivine-gabbro pipelike bodies. The pegmatites are usually resistant lenticular masses that 
support little vegetation, whereas the schistose rocks are more easily weathered and are usually covered by talus and bush.

\section{SCHIST AND GNEISS UNDIVIDED}

Precambrian rocks exposed in the Cerro Sumit quadrangle were màpped as River Portal Mica Schist by Hunter (1925, p. 22). W. R. Hansen (oral commun., 1962), who has recently mapped the Black Canyon, Indicated that the River Portal Mica Schist of Hunter is not a valid stratigraphic unit.

The rocks are predominantly pale-yellowish-brown to olive-black allotriomorphic granular quartz-mica schist, composed mostly of quartz, feldspar, and muscovite, with the muscovite ranging from 15 to about 50 percent. Pink garnet and green hornblende occur locally in the western part of the area where the rocks are also more fissile and micaceous than the dense, somewhat finer grained quartzose phase to the east. A body of amphibolite about 600 feet wide and of undetermined length crops out in the SW数WW sec. 21, T. 49 N., R. 7 W.

Hunter (1925, p. 28) suggested that on the basis of chemical relationships the schist and gneiss were probably of igneous rather than sedimentary origin, even though he recognized that the textural and structural characteristics suggest a sedimentary origin. His chemical analysis of mica schist resembles that given by Pettijohn (1963, p. 7) for some graywackes. Hansen (1964, p. 3) considered the metamorphic rocks of the Black Canyon to be metasedimentary. 


\section{PEGMATITES}

Pegmatites crop out as irregularly distributed bodies throughout the Precambrian area. They range in size from small stringers less than an Inch wide to the large irregular body in Pool Gulch that is about half a mile wide and a mile long. The pegmatites are chiefly lenticular or sill-1ike bodies concordant with the schistosity, but many discordant lenticular and irregular masses are present. Only the larger more resistant pegmatites have been mapped; innumerable smaller ones and some less resistant poorly exposed large pegmatites are not shown on the map.

The pegmatites are mostly white to pink very coarse grained bodies of quartz, feldspar, and mica which have an irregular texture. No other minerals were noted. Hansen (1964, p. 3) recognized three separate periods of pegmatitic intrusion in the Black Canyon area, but no attempt was made to differentlate separate periods of intrusion in the Precambrian of the Cerro Sumit quadrangle.

\section{GABBRO}

Two small pipelike bodies of olivine gabbro crop out near the Cimarron fault in sec. 28, T. 49 N., R. 7 W. The western, more circular body is strongly weathered and poorly exposed. The eastern body is also poorly exposed, but is remarkably fresh compared to the western body. This freshness is attributed to a landslide which removed the weathered material at the surface. The olivine gabbro 18 olive black, coarse grained, and composed predominantly of calcic-plagloclase, olivine, and clinopyroxene. The rock has an ophitic texture with laths of plagioclase as much as 15 millimeters in length. 
The landslide that exposed the fresh gabbro carried large masses of pegmatite, schist, and a mass of the gabbro in such an undisturbed manner that Hunter (1925) mapped the slide mass as Precambrian in place. It is difficult to tell that the slide is not in place because most of the outcrop area of Precambrian rocks is covered with similar-appearing talus and debris. However, the shape of the mass is characteristic of landslide and the unweathered outcrop of gabbro above it appears stripped of the weathered surficial material that characterizes the western body. Some alteration of the schist surrounding the gabbro was noted, but the contact of the gabbro and schist was not seen. The gabbro presumably was intruded after metamorphism of the schist because the gabbro 1s fresh and has a vague alteration halo around 1t, but the time of intrusion is unknown. Erosion has removed the younger overlying rocks that the gabbro might have intruded had it been post-Precambrian. Hansen (1964, p. 3) considered the diabase of the Black Canyon area, which is similar in composition to the gabbro, to be Precambrian in age.

\section{Mesozoic Rocks}

\section{JURASSIC SYSTEM}

In the Cerro Sumit quadrangle, Upper Jurassic rocks include, In ascending order, the Entrada Sandstone and the Wanakah and Morrison Formations. These formations are mostly siope-forming units, are usually obscured by colluvium and brush, and only incomplete sections of each of the formations are exposed. The formations were not studied in detail. 
Entrada Sandstone

The Entrada Sandstone crops out on the north-central border of the quadrangle as a thin slope-forming band of rock that dips steeply to the west. The formation unconformably overlies Precambrian crystalline rocks on a surface of low rellef. The basal 1-2 feet of the Entrada is composed of weathered angular fragments of schist, quartz, and feldspar in a matrix of quartz sand. These pebbles decrease in size and abundance upward Into a white to yellow well-rounded fine- to very fine-grained sandstone distinguished by disseminated well-rounded medium to coarse sand grains.

The maximum thickness of Entrada Sandstone exposed in the quadrangle is about 50 feet, and the Entrada seems to pinch out to the east within the quadrangle. South and west of the exposures, the Entrada thlckens. Cralg and others (1959) reported 85 feet of Entrada at a location near the Black Canyon about 12 miles northwest of the quadrangle.

The contact of the Entrada and the overlying Wanakah Formation. can usually be approximately located because the basal 1 imestone member of the Wanakah is somewhat more resistant to weathering than the sandstones above and below $1 \mathrm{t}$ and, therefore, usually forms a thin ledge. The exact contact, however, was not observed in the quadrangle. In the adjacent area, it 18 sharp and appears to be conformable. No fossils were found in the Entrada. 
Wanakah Formation

The Wanakah Formation consists of interbedded 1imestone, sandstone, and mudstone and crops out in the northeastern part of the Cerro Sumit quadrangle. The basal part of the formation is a finely crystalIine gray limestone bed, 2-3 feet thick, and is poorly exposed. The limestone is overlain by a few feet of less resistant fine-grained yellow sandstone. The overlying part of the Wanakah is mostly covered. This part of the formation is represented by interbedded mudstone, siltstone, and gypsiferous beds in the adjoining area to the northwest (Craig and others, 1959). Considerable movement occurred on the Cimarron fault in this area and it is not unlikely that some of the movement was taken up by squeezing and faulting the gypsiferous upper beds of the Wanakah.

The Wanakah Formation, as redefined by Eckel and others (1949, p. 28), is composed of three members: the Pony Express Limestone Member at the base, the Bilk Creek Sandstone Member, and the marl member at the top. The limestone and the overlying sandstone in the Wanakah of the Cerro Summit area are probably equivalent to the lower two members of Eckel's Wanakah but are too thin and poorly exposed to be examined In detail or mapped separately in the Cerro Summit quadrangle.

The total exposed thickness of the Wanakah is about 50 feet. Craig and others (1959) reported 147 feet of Wanakah on the southwest side of the Black Canyon about 12 miles northwest of the exposures in the Cerro Sumit quadrangle.

The Wanakah Formation exposed on Poverty Mesa occurs as thin discontinuous patches of 1 imestone that apparently rest on the Precambrian. 
The overlying Wanakah beds are covered by colluvium, and the contact with the overlying Tertiary conglomerate was inferred to be at a change In slope.

The character of the contact of the Entrada and the Wanakah is difficult to determine from the poorly exposed outcrops in the quadrangle. The basal limestone of the Wanakah is in part sandy and intraclastic. Presumably, deposition of the limestone occurred over a large area in a shallow sea. The advance of the Wanakah sea could have beveled the Entrada, removing an unknown thickness. The Entrada pinchout could, however, be attributed to nondeposition over a local high. No recognizable fossils were found in the Wanakah. Some of the intraclasts in the basal limestone are laminated in a manner that suggests algal structure.

\section{Morrison Formation}

The Morrison Formation crops out on the north-central border of the quadrangle in brush- and talus-covered slopes. A few sandstone lenses form ledges, but none could be traced for more than a few huriged feet.

The lower part of the Morrison is interbedded lenticular sandstone, siltstone, and mudstone. Thin limestone beds are locally present and the base of the formation was placed below the lowest charophytebearing limy bed. The upper part of the formation is dominantly mudstone but contains sandstone, siltstone, and lenses of conglomeratic sandstone. The mudstone of the lower part is red and green, whereas the mudstone in the upper part is more variable in color, being shades 
of red, green, purple, and gray. Near the contact with the overlying Dakota, the mudstone is white and has a bleached and baked appearance. The manner in which these beds became altered was not determined.

The sandstone is white and green, fine to medium grained, and calcareous. The conglomeratic lenses in the upper sandstone beds are composed of red, green, and black chert granules and pebbles.

Two members of the Morrison Formation, the Salt Wash Sandstone and the overlying Brushy Basin Shale, are recognized in nearby areas of western Colorado. Beds correlative with parts of both members are exposed in fault blocks along the Cimarron fault, but the exposures are poor and the members were not mapped separately.

The thickness of the Morrison Formation is probably about 400 feet at exposures in the northern part of the Cerro Sumit quadrangle. Cralg and others (1959) reported 596 feet of Morrison Formation on the southwest side of the Black Canyon about 12 miles to the northwest.

The only fossils found in the Morrison were charophytes and nondiagnostic ostracodes in a limestone bed near the base of the formation. The following charophytes were identified by Raymond E. Peck (written commun., 1962): Aclistochara bransoni Peck and A. jonesi Peck. Peck indicates that "these are common microfossils from the Upper Jurassic Morrison Fomation" and "Indicate 1acustrine deposition."

\section{CRETACEOUS SYSTEM}

The Cretaceous rocks of the Cerro Sumit quadrangle are, in ascending order, the Dakota Sandstone of Early and Late Cretaceous age and the Mancos Shale, Plctured Cliffs Sandstone, and Fruttland Formation 
of Late Cretaceous age. The bedrock formation over more than 90 percent of the quadrangle is Mancos Shale. The other Cretaceous rocks are present only in small outcrops.

\section{Dakota Sandstone}

The lower part of the Dakota Sandstone crops out along the Cimarron fault near the north-central border of the Cerro Summit quadrangle as a cliff-and ledge-forming unit that caps a few small hills. The exposed Dakota is mainly fine-grained yellowish-brown sandstone with a conglomerate near the base and scattered thin conglomerate lenses. Thin shaly beds are locally exposed and thicker shale beds may be present in some of the covered intervals. The thickness of the different

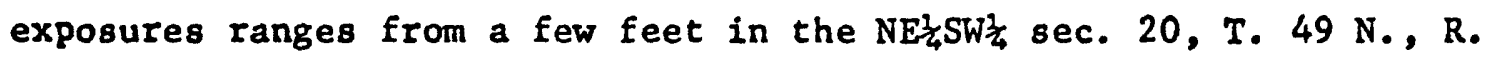
7 W., to about 90 feet in the SW $\frac{1}{4} N W \frac{3}{4}$ sec. 20, T. 49 N., R. 7 W. The upper part of the Dakota is not exposed in the mapped area. The exposures described are separated from the Mancos Shale, which stratigraphIcally overlies the Dakota, by the Cimarron fault.

The following section of the Dakota Sandstone was measured just west of the westernmost fault in the NWh sec. 20 .

Upper and Lower Cretaceous:

Dakota Sandstone:

Top of exposure. Unknown thickness removed by erosion.

1. Sandstone, grayish-orange to yellowish-gray, finegrained; conglomeratic lenses as much as 3 in. thick; massive, cliff-forming-_...

2. Covered, slope-forming-

3. Sandstone, grayish-orange to yellowish-gray, finegralned; scattered conglomeratic lenses; cliffforming-_. 25

4. Covered, slope-forming 12 
Feet

Upper and Lower Cretaceous--Continued

Dakota Sandstone--Continued

5. Sandstone, grayish-orange to yellowish-gray, finegrained; ledge-forming-............

6. Sandstone, very pale orange, fine-grained; conglomeratic lenses as much as $6 \mathrm{in.} \mathrm{thick- \ldots ....} 7$

7. Sandstone, very pale orange, fine-grained.......... 6

8. Conglomerate, grayish-orange, sandy; pebbles as much as 2 in. thick; grades upward to conglomeratic sandstone-1.

9. Sandstone, very pale orange, fine-grained; partly conglomeratic-.....

Partial thickness of Dakota Sandstone-_....-.

Upper Jurassic:

Morrison Formation:

10. Claystone, white, bleached.

In the vicinity of this measured section, the cliff-forming sandstone unit, mapped as Dakota, overlies several hundred feet of typical Morrison beds. Near the contact, the Morrison beds are white claystone and sandstone, bleached of all color and apparently baked. Shaly beds in the overlying sandstone have a simflar appearance. In the measured section, a prominent conglomerate (unit 8) occurs a few feet above the base of the section. About 8 feet of conglomerate similar to unit 8 in the measured section overlies red and purple mudstones of the Morrison in the SW $\frac{1}{4} \mathrm{NE}_{\frac{1}{4}}^{\frac{3}{4}}$ sec. 20, T. 49 N., R. 7 W. The white sandstone below unit 8 is not present, suggesting that the lower sandstone of the measured section is only present locally. The exact relationships are difficult to determine because the rocks are poorly exposed.

The white sandstone at the base of the measured section could be equivalent to the Burro Canyon Formation. In southwestern Colorado, the Early Cretaceous Burro Canyon Formation consists of conglomerate, sandstone, and shale that locally lies between the Morrison Formation 
and the Dakota Sandstone. Iithologically, the coarse part of the Dakota and the Burro Canyon are similar. According to Simmons (1957, p. 2528), an important criterion for distinguishing the Burro Canyon from the Dakota is the abundance of carbonaceous material in the gray shales of the Dakota as compared to the scarcity of carbonaceous material in the greenish-gray shales of the Burro Canyon Formation. The base of the Dakota is usually marked by a conglomerate. The white sandstone at the base of the measured section was included with the overlying Dakota Sandstone because the unit is thin, the shales are colorless, and no carbonaceous material was found.

Iithologically, the Dakota Sandstone in the Cerro Summit quadrangle is similar to the Dakota exposed along the Uncompahgre River to the southwest. The thickness of the Dakota along the Uncompahgre River is about 100 feet; a similar thickness is probably present in the subsurface of the quadrangle.

No fossils were found in the Dakota Sandstone in the Cerro Summit quadrangle. The basal part of the Dakota as mapped in the Cerro Summit area may include rocks equivalent to the Lower Cretaceous Burro Canyon Formation in adjacent areas. A Late Cretaceous age is assumed as that 1s the age of Dakota exposed in nearby areas. R. G. Young (1960, p. 184) reported the presence of the Cenomanian cephalopod Acanthoceras? amphibolum (Plesiacanthoceras amphibolum, table 1 on p1. 1) in a sandstone about 10 feet above the top of the Dakota near De1ta, Colorado, and Pleslacanthoceras wyomingense (Reagan) in a coarse sandstone tongue 30 feet above the top of the Dakota 5 miles southwest of Montrose, Colorad, 
Mancos Shale

The Mancos Shale is the bedrock formation over most of the Cerro Sumit quadrangle south of the Cimarron fault. Landsiide debris and Quaternary deposits, however, cover much of the Mancos and the only good exposures are on steep west- and south-facing slopes along the west side of the quadrangle.

COMPOSITION.--The Mancos Shale is mainly dark-gray to black marine shale; 1t weathers light gray to olive gray and is typicaliy fissile. The shale is calcareous, silty, sandy, and carbonaceous in varying amounts. Dark-gray limestone locally occurs as lenticular and concretionary masses. Bentonitic beds, usually less than 6 inches thick but as much as 2 feet thick, crop out locally in the Mancos. Two zones within the Mancos of the Cerro Summit quadrangle have lithologic and weathering characteristics which make the zones easy to map. The lower zone, which crops out as a dark band along the west side of the quadrangle, will be referred to as the bentonitic-marker bed. The upper zone crops out in the southeastern part of the area and will be referred to as the silty-marker bed.

The lower one-fourth to one-third of the Mancos is not exposed In the quadrangle. The oldest exposed Mancos is along the west side of the quadrangle where between 200 and 400 feet of seemingly featureless dark shale crops out below the bentonftic-marker bed. Locally, concretionary beds are present, but they are difficult to trace. A falrly persistent 1 imestone bed about 2 feet thick crops out approximately 10 feet below the bentonitic-marker bed. 
The bentonitic-marker bed is a series of thinly laminated concretionary shales about 50 feet thick. Presumably, several thin bentonIte beds are present but the character of the beds is difficult to determine. The over-all outcrop is marked by yellowish iron oxide and gypoum that occur throughout the unit as lenticular and disseminated masses along bedding planes and as veinlets filling randomly oriented joints.

The lower 400 feet in the zone between the bentonitic- and silty-marker beds is well exposed along the west border of the quadrangle and consists of olive-gray to olive-black shale and local beds of limestone concretions. About 400 feet above the bentonitic-marker bed the shale weathers to a grayish yellow, probably because of increased lime content. The yellowish-weathering shale tends to be somewhat more resistant to weathering and can usually be seen as a yellow band when the light is from the right direction. The interval between this yellowish-weathered shale and the silty-marker bed is mostly covered by landslide debris and is not well known. Some unusually large, almost round, finely crystalline dense concretions occur in the shaly landslide debris on the north side of Cedar Creek near Cerro Summit. Some of the concretions exposed in the roadcuts are as much as 4 feet in diameter. It could not be determined if the concretions are from a single bed or are randomly distributed. Silty beds that probably occur about midway between the bentonitic- and silty-marker beds crop out in the roadcut

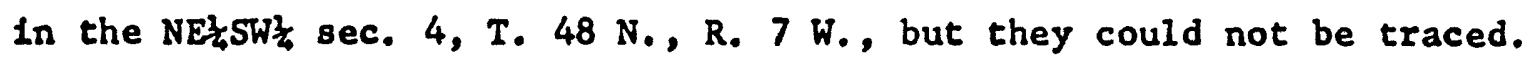


The hill in which they occur is isolated, and the character of the outcrops suggests that the beds are not in place.

The silty-marker bed, about 150 feet thick, consists of interbedded sandstone, siltstone, and limestone. The sandstone and siltstone at the top of the unit is calcareous and these beds form thin resistant ledges. The following partial measured section of the silty-marker bed 18 typical of this unit.

Upper Cretaceous:

Mancos Shale, silty-marker bed:

Top covered by landslide.

1. Sandstone and siltstone, 1ight-olive-gray; grades to olive-black shale at top; slope- and ledge-

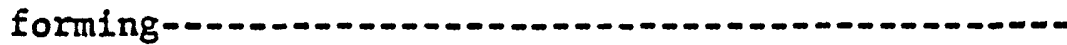

2. Sandstone and siltstone, light-olive-gray; ledgeforming; Ophiomorpha very common-..............-

3. Siltstone, Iight-olive-gray, partly calcareous;

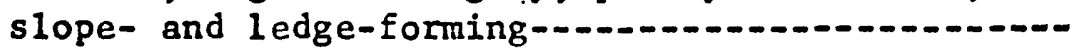

4. Siltstone, 1ight-olive-gray, calcareous; ledgeforming; nonpersistent; Ophiomorpha-............-.

5. Sandstone and siltstone, light-olive-gray; some interbedded olive-black silty shale; slope- and

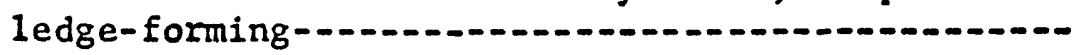

6. Siltstone, olive-gray, calcareous; forms persistent ledge; Oph1omorpha-................................

7. Sandstone and siltstone, light-olive-gray; some olive-black interbedded silty shale; slope- and ledge-forming-......................................

8. Limestone and silty limestone, olive-gray; ledge-

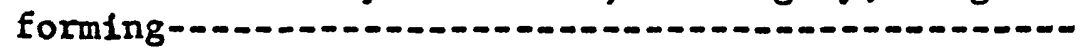

9. Siltstone, light-olive-gray, calcareous; slopeforming--..-...-...

Total exposed thickness of silty-marker bed--.--

Base of section covered by landslide.

The shale above the silty-marker bed cannot be readily distinguished from that below it. In places, the upper shale beds appear to be less calcareous and sandy. A bentonite bed as much as 2 feet thick 
crops out in a landslide scarp about 240 feet below the top of the for-

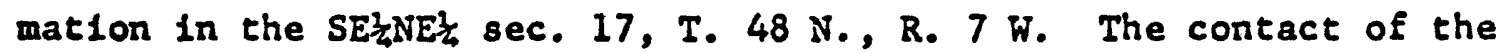
Mancos Shale with the overlying Pictured Cliffs Sandstone is conformable.

THICKNESS.--The contact between the Mancos Shale and the Dakota Sandstone is not exposed in the quadrangle. In the northeastern part of the quadrangle, the Mancos is separated from nearby exposures of Dakota by the Cimarron fault. The nearest exposure of the contact of the Mancos and the Dakota is about 7 miles west in the Uncompahgre River valley. The lack of nearby exposures of the base of the Mancos coupled with the poorly known structure make it impossible to determine an accurate thickness for the Mancos. Based on projections from the Uncompahgre River valley to the Cerro Sumit and Cimarron Ridge areas, the thickness of the Mancos is between 3,500 and 5,500 feet. The 811ty-marker bed occurs about 700 feet below the top of the Mancos and the bentonitic-marker bed seems to be between 1,400 and 2,200 feet above the Dakota Sandstone.

FOSSTS.--Previous to this study, fossils had not been reported from the Mancos Shale in the Cerro Sumit area. Landslides obscure otructure in the rocks, but in most places the landslide debris had not or did not appear to have moved far. Delineation of fossil zones, therefore, offered a way to determine the general structure as fossils could be collected from the Mancos involved in landsliding. Fossils were collected at every opportunity and many only through considerable time and effort. In critical àreas, some localities were visited 
several times in an effort to find zonal representatives. Fossils were collected from more than 40 localities in the general area (table 1 on p1. 1; table 3), and many of these localities are in landslide debrio that was derived primarily from Mancos Shale. The limited value of the collections from landsilde in determining atructure is recognized because a complete reference section with measurable interval thicknesses could not be established. However, as a result of these collections, at least nine of the recognized Upper Cretaceous faunal zones are now known to be present in the Mancos Shale of the area.

Most of the fossils collected from the Mancos Shale have been Identified by W. A. Cobban of the U.S. Geological Survey (written commun., 1961-64). A collection of gastropods (USGS Mesozolc locality D3861) was identified by N.F. Sohl of the U.S. Geological Survey (written commun., 1962-63).

The oldest faunal zone from which fossils were collected is that of Scaphites warreni (USGS Mes. 1ocs. D3841, D3842) from the lower part of the Mancos Shale exposed west of the Cerro Summit quadrangle In the Uncompahgre River valley. According to Cobban, the fossils of locality D3841 are characteristic of the Juana Lopez Member of the Mancos Shale of southern Colorado and northern New Mexico. Within the quadrangle, the oldest faunal zone from which fossils were collected is in concretlonary shales on the west-central border of the quadrangle. According to Cobban, the abundance of Baculites asper Morton in the collection (USGS Mes. Loc. D3844) suggests assignment to the zone of Scaphites depressus. Presumably, this collection 18 from below the 
bentonitic-marker bed. If no faulting occurs in the nearby area, the bentonitic-marker bed should be beneath the landslide cover about 350 feet above locality D3844.

Fossils were not found in the bentonitic-marker bed or in the beds Immediately above or below it. Baculites asperiformis Meek (USGS Mes. Iocs. D3846, D3847) was collected from black concretionary shales about 270 feet above the bentonitic-marker bed on the northwest border of the quadrangle.

In the same area, Baculites perplexus Cobban (USGS Mes. 1oc. D3851) was collected approximately 465 feet above the bentoniticmarker bed. Cobban (written commun., 1962) states, "These specimens from a highly septarlan concretion are almost smooth which indicates a very low position in the $\underline{B}$. perplexus zone." Baculites perplexus Cobban was collected from several localities in roadcuts along U.S. 50. Several of these localities may be from undisturbed shales in the lower part of the cuts, but in most places some part of the highway cut shows evidence of landslide movement; Mancos Shale is shown on the map only where landsliding is not suspected.

The highest topographic, and presumably the highest stratigraphic, collection from the Baculites perplexus zone was from the south roadcut at Cerro Sumit (USGS Mes. 10c. D3873). The thickness of the interval between localities $D 3851$ and $D 3873$ is not readily determinable because the attitude of the beds between the two localities is unknown. 
Baculites scotti Cobban was collected from slumped Mancos Shale east of Cimarron Creek but the position of the collection with respect to a known marker bed is unknown.

Well-preserved zonal representatives were not found in the 811ty-marker bed. One large crushed baculite was collected from near the top of the unit south of Coal Hill (USGS Mes. 1oc. D3177). Cobban identified this fossil as Baculites pseudovatus Elias? and indicated that it could be from the zone of Didymoceras nebrascense. Above the silty-marker bed in the SW $\frac{1}{4} \mathrm{SW}_{\frac{1}{4}}$ sec. 22, T. 48 N., R. 7 W., Didymoceras nebrascense (Meek and Hayden) (USGS Mes. 10C. D3859) was collected in float at the bottom of a small gully. The point of collection was about 160 feet above the silty-marker bed and all that is known is that this zone is present at least this high above the silty-marker bed. The youngest faunal zone from which fossils in the Mancos Shale were collected in the quadrangle is that of Exiteloceras jenneyi (Whitfield) (USGS Mes. 1oc. D3178) from recent and active landslide debris along the Hairpin Ditch, west of Coal Hill. Baculites rugosus Cobban was collected from ditch-bank material at the locality; the specimen of Exiteloceras jenneyi was from a concretion located at the toe of the landslide debris that came from the scarp just below the ditch. Presumably, these fossils are from beds about 240 feet below the base of the Pictured Cliffs Sandstone.

Baculites aff, rugosus Cobban (USGS Mes. 1oc. D3861) of the zone of Didymoceras cheyennense was collected from landslide debris that definitely came from the upper few feet of the Mancos Shale in 
the SW $\frac{1}{4}$ SW $\frac{1}{4}$ sec. 8, T. 47 N., R. 7 W. (approximate). The locality is at the base of the best exposure of Pictured Cliffs Sandstone and Fruitland Formation in the area. This collection is especially significant because it defines the top of the Mancos Shale in the Cerro Summit area with some precision and permits definite correlation of the overlying coal-bearing beds with the Pictured Cliffs and Fruitland sequence at Durango.

Gastropods were also collected at USGS Mes. loc. D3861 (see table 3 for complete list). N. F. Sohl (written commun., 1962, 1964) reports that Acirsa (Hemiacirsa?) sp., Morea aff. M. corsicannensis Stephenson, and Hercorhyncus sp. from this locality are common to the upper part of the Upper Cretaceous sequence of the Gulf Coastal Plain, but have not previously been reported in the. Upper Cretaceous of the western interior.

The Acirsa is not well enough preserved for close comparison with Gulf Coast species. The Morea is of the cancellaria lineage. In having a depressed spire it is similar to a subspecies of $M$. corsicannensis $I$ am describing from the Coffee Sand of Mississippi. That is to say it is more like the Moreas found in the Exogyra ponderosa zone than those of the E. costata zone.

The Hercorhyncus has a double row of peripheral nodes and appears to be a new species.

Regarding the whole gastropod collection, Sohl states,

Few of these species are conmon to equivalent units of the Pierre Shale of the Front Range. However, the affinities of this fauna with the Campanian gastropod faunas of the Gulf Coast is unmistakable. Similar species are to be found in the clayey-sand facies in the Coffee Sand and Coon Creek Tongue of the Ripley Formation of Mississippi and Tennessee.

Presumably, the Cerro Sumit area was nearer to the shoreline at this time than was the Front Range area. 
DEPOSITIONAL CONDITIONS AND CORRELATIONS.--The sediments of the Mancos Shale were fine muds deposited in a sea that covered the Cerro summit area seemingly continuously from Cenomanian through middle Campanian time. The presence of sand and silt in the silty-marker bed suggests proximity of the shoreline; the silty-marker bed may, therefore, be related to one of the regressive-transgressive movements of the shoreline during Mancos time. Spieker (1949, p. 74) has related coarse conglomerates of the Indianola Group in Utah, which are equivalent to the Mancos Shale, to orogenic pulses in the source area, but he was unable to definitely relate all the regressive and transgressive movements of the Upper Cretaceous shoreline to orogeny. The regressive-transgressive movements of the shoreline may have been the result of interaction between the rate of subsidence and the rate at which sediment was supplied. The type of sediments that were deposited at any one place in the basin would be dependent on this interrelationship. Several regressions and transgressions of the sea are recognized In the Mancos Shale of nearby areas. These movements are described in the following paragraphs because they are Important in determining the exact correlation of the Mancos Shale in the Cerro Summit area with rocks in other areas.

Welmer (1960) has summarized the major regressive-transgressive cycles in the Upper Cretaceous sediments of Colorado. Zapp and Cobban (1960, p. 247) diagramed the regressive-transgressive cycles of northwestern Colorado in more detall. These cycles show an eastward wthdrawal of the sea interrupted by many partial readvances. 
The first regressive-transgressive cycle that affected colorado Is expressed in the beds of the type Mesaverde Group of southwestern Colorado (table 1 on $\mathrm{pl}$. 1). Fossils representative of Mesaverde time in the type locality were not found in the Cerro Summit area. The beds near the bentonitic-marker bed probably are equivalent to the type Mesaverde Group. The normal marine sediments of the Cerro Sumit and Grand Mesa areas indicate that the strand line of this early Campanian regression did not extend into these areas. Baltz (1955, p. 21) reported that the Mesaverde can be seen to pinch out to the northeast in the Disappointment Creek valley area about 60 miles southwest of the Cerro Summit area.

Transgression of the sea following the Mesaverde regression is expressed by the westward overlap of the Lewis Shale. Several regressivetransgressive cycles occurred in northwestern colorado during the time that the Lewis Shale was being deposited in southwestern Colorado. The first of these cycles is expressed along the Utah border in northwestern Colorado by the Castlegate-Rimrock regression (Zapp and Cobban, 1960, p. 248). Zapp and Cobban (1960, fig. 112.2) show sandy beds which are apparent1y equivalent to the Castlegate-Rimrock regression to be in rocks below a collection of Baculites $n$. sp. "E" (Baculites perplexus) and above rocks containing Baculites asperiformis. In the Cerro Summit area, the rocks containing these fossils are thick and poorly exposed. It is not known if sandy beds equivalent to the Castlegate-Rimrock regression are present. The sandstone of this pulse has been related to orogeny in the source area by Spieker (1949, p. 70-73) 
The first regression following the Mesaverde regression to affect Colorado to any extent was the lower Iles (Zapp and Cobban, 1960). The strand line of this regression extended well into northwestern Colorado, but southwestern Colorado was not affected and continued to raceive marine eadiments. Rocke equivalent to this regression are mostly covered in the Cerro Summit area and it is not known if sandy beds representative of the regression are present in the Mancos of the Cerro Summit area.

The next regression (middle Iles-Palisades regression, Zapp and Cobban, 1960) extended farther east into northwestern Colorado and 1s expressed in the Book Cliffs area by the Sego Sandstone of the Mesaverde Group ${ }^{1}$ near Palisade. The silty-marker bed of the Cerro Summit area, which appears to be in the zone of Didymoceras nebrascense may be a marine sand related to this regression.

The lower Williams Fork-1ower Bowie regression (Zapp and Cobban, 1960 , p. 248), which followed the upper Iles-lower Mount Garfield transgression, terminated marine deposition in southwestern Colorado. The Pictured Cliffs Sandstone of southwestern Colorado and the Rollins Sandstone Member of the Mesaverde and Trout Creek Sandstone Member of the Iles of northwestern Colorado are basal sandstones of this regression. The Pictured Cliffs Sandstone, which overlfes the Mancos in the Cerro Sumit area, is believed to be related to this regression on the basis of the following fossil data.

1. See page 37 for discussion of the Mesaverde problem. The name Mesaverde is used in northern Colorado for rocks that do not appear to be equivalent to those of the type Mesaverde Group in southern Colorado. 
In the Durango region, the precise age of the top of the Lewis Shale is still undetermined. The youngest reported fossil zone from the Lewis Shale is that of Exiteloceras jenneyi (Ancyloceras sp. of Lee and Knowlton, 1917, p. 190) from near Dulce, New Mexico. Cobban (oral commun., 1964) collected baculite fragments in the Dulce area near Durango, Colorado, that suggest that the zone of Didymoceras cheyennense is within 50 feet of the top of the Lewis Shale. In the Cerro Summit area, Baculites aff. rugosus, an indicator of the zone of Didymoceras cheyennense, was collected from the upper few feet of the Mancos Shale. This suggests that the upper part of the Lewis Shale of the Dulce area Is a time equivalent of the upper part of the Mancos Shale in the Cerro Summit area.

In the Grand Mesa area, Zapp and Cobban (1960, P. 247, fig. 112.2) show Didymoceras stevensoni to occur about 250 feet below the Rollins Sandstone Member of the Mesaverde. In the Cerro Summit area, the zone of Didymoceras stevensoni has not been definitely identified. The next younger zone (Exiteloceras jenneyi) is about 240 feet below the top of the Mancos in the Cerro Summit area and the D. stevensoni zone is probably not far below it.

\section{Pictured Cliffs Sandstone}

The Pictured Cliffs Sandstone crops out as a slope-forming unit at Coal Hill on the east-central border of the quadrangle and in several isolated patches east of Waterdog Peak. The upper part of the formation is locally well exposed, but the lower part is usually covered by slope wash and landsilde debris. The formation 18 well exposed in a few 
landsilde scarps and much of the information here is based on those exposures.

The lower part of the Pictured Cliffs Sandstone is interbedded fine-grained pale-olive sandstone and olive-black shale. The basal part is gradational with the underlying Mancos and the contact is placed where the sandstone predominates over shale. The upper part of the formation is massive-bedded fine-grained white to gray sandstone. The sand is subrounded to angular, feldspathic, and speckled with black chert grains.

In the Cerro Sumit quadrangle, the Pictured Cliffs Sandstone is 200-250 feet thick. The following partial section was measured in

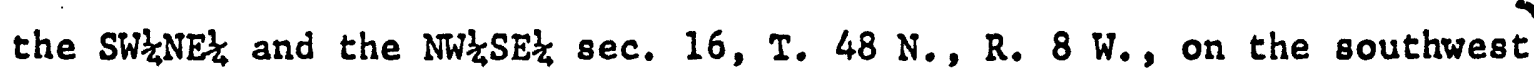
side of Coal Hill.

Upper Cretaceous:

Fruitland Formation:

1. Carbonaceous sandstone and coal at base, overlain by interbedded sandstone, shale, and coal-......

Plctured Cliffs Sandstone:

2. Sandstone, dusky-yellow to yellowish-gray, fineto medium-grained; many black chert grains; occasional dark-yellowish ferruginous concre-

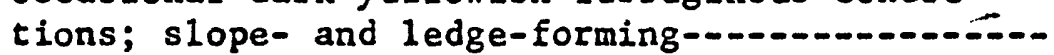

3. Sandstone, yellowish-gray, fine-grained; fewer black chert grains than unit above; slope- and

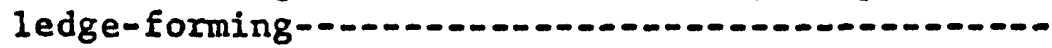

4. Covered, probably interbedded sandstone, siltstone, and shale; slope-forming-....

5. Sandstone and siltstone, yellowish-gray; slopeand ledge-forming-_.

6. Sandstone, siltstone, and shale, interbedded, dusky-yellow to olive-gray; mostly slope forming, some thin discontinuous calcareous ledges-

Total exposed Pictured Cliffs Sandstone-.....-

Base of section covered by landslide and colluvium. 
Few fossils were found in the Pictured Cliffs Sandstone. A small collection (USGS Mes. 10c. D3176) from float on the side of the small cone-shaped hill at the south end of Coal Hill Includes the followIng marine fauna (Cobban, written commun., 1961, 1962):

Inoceramus cf. I. Sagensis Owen

Tellina sp.

Pteria linguaeformia (Evans and Shumard)

Cardium sp.

Cymbophora sp.

Placenticeras sp.

The lower marine beds of the Pictured Cliffs Sandstone are overlain by littoral beds in the upper part of the formation. The sandstone of these upper beds is difficult to distinguish from the sandstone beds in the overlying coal-bearing Fruitland Formation. The contact is arbitrarily placed at the lowest coal bed present.

Fossils in the Pictured Cliffs of the Cerro Sumit area are of little value in establishing an exact correlation with other areas. Fossils in the upper part of the underlying Mancos Shale indicate that the Pictured Cliffs probably correlate with the Rollins Sandstone Member of the Mesaverde Formation (Grand Mesa area) and the Pictured Cliffs Sandstone of the Dulce area rear Durango. Physical tracing of the Pictured Cliffs to these areas, however, is not possible.

\section{Eruitland Formation}

The Fruitland Formation crops out at the top of Coal Hill where 1t forms ledges and slopes and also in the brush- and tree-covered 
ridge east of Waterdog Peak. Only 20 to 30 feet of the formation is preserved in Coal Hill, and probably less than 50 feet occurs in the outcrops east of Waterdog Peak. These outcrops are erosional remnants of formerly more extensive and thicker Upper Cretaceous rocks.

In the adjacent area to the south the coal-bearing beds of the Fruitland Formation are more than 200 feet thick. Overlying the Fruitland Formation in the Cimarron Ridge area are 500-600 feet of interbedded sandstone and shale of the Upper Cretaceous Kirtland Shale.

At Coal Hill, 3 feet of coal, underlain by about 1 foot of sandy coal and brown carbonaceous shale, forms the base of the Fruitland Formation. The coal is overlain by 2-5 feet of brown carbonaceous shale that is overlain by a bed of oyster shells (Ostrea subtrigonalis Evans and Shumard, USGS Mes. 10c. D3175; Cobban, written commun., 1961), which ranges in thickness from a few inches to about 2 feet. Interbedded sandstone, shale, and thin coal beds probably overlie the oyster bed, but the interval is poorly exposed and was not examined in detall. The character of the Fruitland Formation along the ridge east of Waterdog Peak is difficult to determine because of the discordant dips between the varlous outcrops and the lack of traceable beds. Only scattered small exposures of weathered coal, carbonaceous shale, and clinkered rock where the coal has burned can be found. In the SW $\frac{1}{4}$ SW $\frac{1}{4}$ sec. 28, T. 48 N., R. 7 W., the occurrence of burned trees on the clinkered outcrops suggests that some of the coal burned recently. The following section, which is probably representative of the Fruitland Formation in the quadrangle, was measured in $a$ landslide 


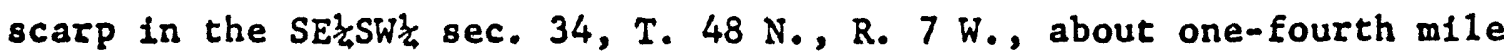
south of the southeast corner of the quadrangle.

Feet

Upper Cretaceous:

Fruitland Formation (partial):

Cover.

1. Shale, brown to black, carbonaceous-...

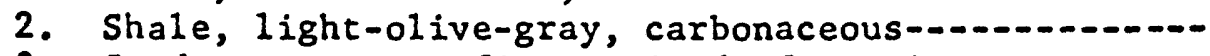

3. Sandstone, gray, fine-grained; ferruginous concretions-......

4. Shale, brown, carbonaceous

5. Shale, gray; limestone concretions-_.

6. Coal to bony coal

7. Shale, light-olive-gray, carbonaceous; olive limestone concretions-..

8. Shale, brown to black, carbonaceous; partly bony coal--

9. Shale, gray-

10. Shale, brown, carbonaceous-

11. Sandstone, white, fine-grained-_-

12. Coal-......

13. Shale, brown, carbonaceous-_.

14. Sandstone, white, fine-grained; thin intercalations of brown carbonaceous shale-....

15. Coquina bed of Ostrea subtrigonalis Evans and Shumard-.........

16. Shale, brown, carbonaceous -

17. Shale, gray-ar.

18. Shale, brown, carbonaceous -

19. Coal- Col

20. Shale, brown, carbonaceous -

21. Sandstone, white to gray; thin intercalations of brown carbonaceous shale-..8

22. Shale, brown, carbonaceous; contains yellow iron

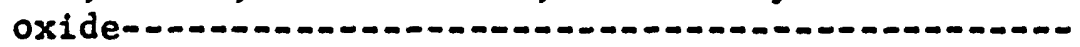

23. Coal-- Co-

24. Coal, sandy

25. Shale, brown, sandy, carbonaceous-n-

Total thickness, Fruitland Formation (partial)

\section{Pictured Cliffs Sandstone:}

Sandstone, white, fine-grained-10. $20.0+$

The only fossils found in the beds of the Fruitland Formation In the quadrangle were the Ostrea collected on Coal Hill (USGS Mes. 1oc. D3817). In adjoining areas, gastropods and pelecypods are present 
along with the oysters but they are long-ranging brackish-water species and do not indicate the age of the rocks. The age of the formation is assumed to be late Campanian and possibly Maestrichtian on the basis of the presence of Baculites aff. rugosus at the top of the Mancos Shale and pollen of possible Maestrichtian age in fine-grained sandstone in the Kirtland Shale about 800 feet above the base of the Fruitland Formation at the north end of Cimarron Ridge (E. B. Leopold, written commun., 1965; USGS Paleobot. 10C. D1977B).

Mesaverde problem

Cross, Howe, and Irving (1907, p. 6) included the coal-bearing sandstone and shale beds which overlie the Mancos Shale in the Cerro Sumit area with the Mesaverde Formation. My studies indicate that these beds actually correlate with the Pictured Cliffs Sandstone and the Fruitland Formation of the Durango area, formations that are separated from the type Mesaverde by the Lewis Shale. The name "Mesa Verde group" was originally applied in southwestern Colorado (Durango region) to a series of dominantly continental coal-bearing sandstone and shale beds enclosed between marine shale beds (Holmes, 1877, p1. 35). Later, Cross and Spencer (1899, p. 4) used the name "Mesaverde formation" for the continental beds of Holmes and named the underlying rocks the Mancos Shale; they named the marine rocks above the coal-bearing beds the Lewis Shale.

In the Yampa coal field area about 200 miles north of the Durango region, Fenneman and Gale $(1906$, p. 22, 28) found a similar sequence of coal-bearing sandstone and shale enclosed by marine shales. 
They used the names Mancos Shale, Mesaverde Formation, and I, ewis Shale in the "expectation that future geologic work will definitely establish the correlation" between the formations. Before detailed regional correlations based on faunal evidence were made, the name Mesaverde was widely used in northwestern Colorado (Richardson, 1907; Gale, 1909; and others) and it became well entrenched in the literature.

In the Grand Mesa area, about halfway between the Yampa and Durango areas, Eldridge (1894, p. 6) applied the name Laramie to coalbearing sands and shales above his Montana Formation. Later, Lee (1909, p. 322) used the name Mesaverde Formation for those coal-bearing beds and the name Mancos Shale for the rocks below. The Mesaverde Formation of Lee included, in ascending order, a massive sandstone (Rollins Sandstone Member), a coal-bearing brackish-water shale (Bowie Shale Member), a nonmarine shale (Paonia Shale Member), and undifferentiated sandstone. According to Lee, an unconformity separated the Bowie and Paonia Shale Members, but no Lewis Shale was recognized over the Mesaverde.

Lee and Knowlton (1917, p. 219) first suggested that the concem lation between the type locality and Grand Mesa was incorrect. They state:

The 'Laramie' formation of southwestern Colorado, consisting of a basal sandstone (the Pictured Cliffs Sandstone), containing marine invertebrates and overlain by coal-bearing shale and sandstone [the Fruitland Formation] that contains brackish water invertebrates $* * *$ is comparable both lithologically and faunally to the Rollins Sandstone of the Grand Mesa Field with its marine invertebrates overlain by coalbearing sandstone and shale (the Bowie Shale Member of the Mesaverde with its marine and brackish-water invertebrates). 
Lee and knowlton concluded that there is no evidence that the rocks of the two areas were deposited in separate basins of deposition and that the rock formations once extended continuously over the intervening axea.

The name Mesaverde, however, continued to be used in the Grand Mesa-Book Cliffs area (Erdmann, 1934; Fisher, 1936) and elsewhere in northwestern Colorado. Earlier, Spieker and Reeside (1925, p. 442) emphasized that the name had had rather widespread and loose usage and that its present (1925) significance was of lithology rather than of time. The lithologic similarity of rocks in the Grand Mesa-Book Cliffs area to the type Mesaverde is limited to the lower or regressive part of the formation because a thick Lewis Shale is not present over the Mesaverde.

In the Lou Creek area 12 miles south of the Cerro Summit quadrangle, Cross, Howe, and Irving (1907, p. 6) applied the name Mesaverde Formation to coal-bearing beds that were "much obscured by glacial and landslide debris." The rocks that enclosed the coal beds were reportedly not exposed and the coal-bearing formation could be neither measured nor described. The contact with the underlying shale was $" * * *$ purely hypothetical ***" $(1907$, p. 6) and was drawn with reference to outcrops of coal seams as shown by old workings. Presumably, the coal-bearing formation was referred to the Mesaverde Formation because of its relation to the Mancos Shale.

The writer has traced, through discontinuous outcrops, the coll-bearing rocks from the Cerro Sumit quadrangle to the Mesaverde 
Formation of Cross, Howe, and Irving (1907) at Lou Creek and has found them to be lateral equivalents. The upper part of the Mancos Shale of the Cerro Summit area, from fossil evidence, is equivalent to the upper part of the Lewis Shale of the type locality. On the basis of this correlation, the sandstone that overlies the Mancos of the Cerro Sumit area is correlative with the Pictured Cliffs Sandstone and the overlying coal-bearing beds are correlative with the Fruitland Formation of the Durango region and not with those of the Mesaverde Group. Sandstone that would correlate with the type Mesaverde Formation did not extend as far north as the Cerro Summit area. The name Mesaverde, therefore, should not be applied to rocks in the Cerro summit area.

Rocks of Late Cretaceous and Tertiary Age in the Adjacent Cimarron Ridge Arrea

Several rock units of Late Cretaceous and Tertiary age which may have been deposited in the quadrangle crop out in the adjacent Cimarron Ridge area. The following brief discussion of these Upper Cretaceous and Tertiary rocks is included in this report to facilifate discussion of the structure and geologic history of the Cerro sumit area. The rock units (fig. 2; table 2), in ascending order, include the Upper Cretaceous Fruitland Formation and Kirtland Shale undivided, unnamed Upper Cretaceous volcanic conglomerates and tuff breccias, the Tertiary Telluride Conglomerate, the middle and upper Tertiary San Juan Formation, and welded tuffs of the middle and upper Tertiary Potosi Volcanic Group. Of these rock units only the lower part of the Fruitland is present in the Cerro Sumit quadrangle. 


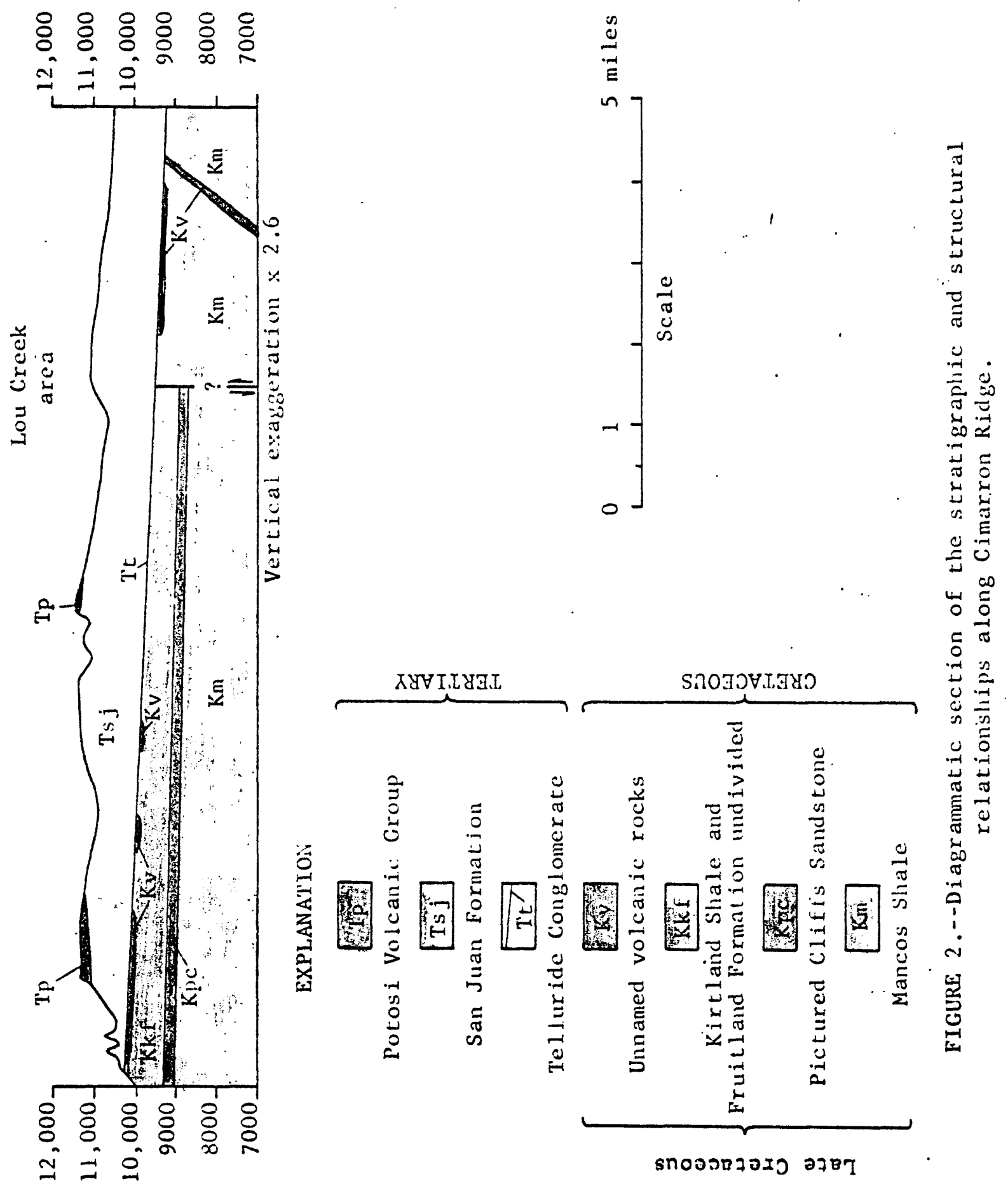


FRUITLAND FORMATION AND KIRTLAND SHALE UNDIVIDED

The Fruitland Formation and Kirtland Shale undivided crop out in isolated landsilde scarps along Cimarron Ridge. The rocks consist of 200-300 feet of interbedded sandstone, shale, and coal in the lower part of the unit and 500-600 feet of interbedded sandstone and shale in the upper part. The rocks are poorly exposed and they usually are difficult to divide. The coal-bearing lower part of the unit is believed to be equivalent to the Fruitland Formation of the Durango, Colorado, area, and the upper part of the unit to the Upper Cretaceous Kirtland Shale of the Durango area.

Locally, coarse white feldspathic sandstone with scattered lenses of sandy chert-pebble conglomerate crops out at the top of the Fruitland Formation and Kirtland Shale undivided. Some red to purple sandstone and shale are also present. These beds contrast markedly with the underlying fine-grained yellow sandstone and olive shale. The relationship of the coarser beds to the finer ones could not be determined because the zone between the coarser and finer beds is not exposed. The coarser beds may have been deposited during a period of erosion in Late Cretaceous time that followed deposition of the Fruitland Formation and Kirtland Shale undivided.

The Fruitland Formation and Kirtland Shale undivided conformably overlie the Pictured Cliffs Sandstone and are unconfomably overlain by unnamed volcanic rocks of Late Cretaceous age or by the Tellurlde Conglomerate of Tertlary age. 
The age of the Fruitland Formation and Kirtland Shale undivided is Late Cretaceous. The beds are believed to be Campanian and Maestrichtian in age. Pollen from shale beds between 100 and 200 feet below the top of the formation (USGS Paleobot. 1oc. D1978) is of Late Cretaceous age, possibly Maestrichtian (E. B. Leopold, written commun., 1965). Miss Leopold states that the sample "contains pollen of PachysandraSarcococca which according to our current records is not yet recorded in pre-Maestrichtian sediments regionally."

\section{UPPER CRETACEOUS VOLCANIC ROCKS}

Volcanic rocks of Late Cretaceous age crop out in a small area southeast of the Cerro Sumit quadrangle and in discontinuous cliffs and ledges along Cimarron Ridge. This previously undescribed unit consists of volcanic conglomerate and tuff breccia interbedded with volcanic-derived sandstone and shale. Boulders are as much as or more than 2 feet in diameter. Some of the tuff breccia may be pyroclastic in origin. In the Lou Creek area (figs. 1 and 2 ) the unit includes flows, flow breccias, and tuff breccias. Probably, most of the rock in the unit is quartz-1atite. As much as 200 feet of the volcanic unit is preserved as discontinuous erosional remnants; originally, the unit was probably thicker and more extensive.

Locally, the lower beds of the volcanic conglomerate are carbonaceous and leaf bearing, and a sillcified tree stump, about 3 feet in diameter, was noted. Megafossil and microfossil material was collected from the carbonaceous beds at three localities along the northeastern side of Cimarron Ridge. Though the outcrops from which the fossils 
were collected are separated by intervals of dense tree cover and surficial deposits, the carbonaceous beds are similar in lithology and seem to be at or near the same stratigraphic horizon. Fossil leaves from the three localities were examined by J. A. Wolfe (written commun., 1962, 1964), and pollen in the leaf-bearing matrix of one locality was examined by E. B. Leopold (written commun., 1964). Wolfe reported that the fossil leaves in two of the collections indicate a Paleocene age and those in the third indicate a Late Cretaceous age. Pollen (USGS Paleobot. 1oc. D1977B) in the matrix of one of the collections, indicated to be of Paleocene age by leaves, is of Late Cretaceous age according to Leopold. Concerning the conflict in reported age of the fossils, Wolfe (written commun., 1964) concluded that the phylogenetic and stratigraphic significance of the leaf species in the Rocky Mountain Cretaceous and Paleocene is Iargely unknown and that the palynological data should be given more weight than the megafossil data.

Leopold (written commun., 1965) also reported that the florule from the volcanic unit (USGS Paleobot. loc. D1977D) appears to be younger than the florule from the underlying Fruitland Formation and Kirtland Shale undivided. On the basis of this data the unnamed volcanic rocks are considered to be Late Cretaceous (perhaps Maestrichtian) in age.

Isotopic age determinations (R. F. Marvin, written commun., 1966) of samples of tuff breccia and a related dike near Lou Creek average 66 million years. This age 18 about middle Maestrichtian 
(Kulp, 1961, P. 1111) and it agrees with the Maestrichtian age suggested by the pollen data.

The volcanic debris in the unit appears to have been derived from volcanic centers in the Ouray and Cow Creek areas and from a dike about 3 miles south of Lou Creek. Burbank (1930, p. 201) recognized that the Intrusives at Ouray and Cow Creek were Late Cretaceous or Eocene [Paleocene] In age on the basis of their relationships with the Telluride Conglomerate and the Mancos Shale. Burbank (1930, p. 204) suggested that these intrusives were one of several volcanic centers in the San Juan Mountains area that erupted debris which contributed to the Iithic tuffs of the Animas Formation. He concluded, however, that pre-Telluride erosion removed all vestiges of the extrusive debris near Ouray. The discovery of the extrusive rocks in the Cimarron Ridge area confirms Burbank's conclusions concerning the age of the intrusives at Ouray and Cow Creek and proves the existence of a period of volcanism In Late Cretaceous time.

The original extent of the Upper Cretaceous volcanic conglomerate is unknown because the unit now consists of discontinuous erosional remnants. An elongate hill composed of the volcanic conglomerate occurs one-fourth mile east of the southeast corner of the quadrangle. The volcanic conglomerate overiles the Fruitland Formation, but the contact is not exposed. The hill could be either an erosional remnant or a klippe. This northernmost exposure of the volcanic conglomerate is at an altitude of about 9,500 feet. The volcanic conglomerate could have 
extended across the Cerro Summit area to Poverty Mesa, which now has an average altitude of about 9,500 feet.

Along Cimarron Ridge, the volcanic unit appears to unconformably overlie older rocks on a surface of low relief. Along the north end of Cimarron Ridge the unit overlioe the undivided Kirtland Shale and Fruitland Formation. In the Nate Creek area (SW $z_{4}$ SW R. 7 W.), tuff breccia and flow breccla overlie baked and contorted Mancos Shale. The volcanic unit is unconformably overlain by the Telluride Conglomerate and the San Juan Formation.

\section{TELIURIDE CONGLOMERATE}

The Telluride Conglomerate crops out along Cimarron Ridge as a greenish-gray ledge-forming conglomerate that ranges from a few feet to about 50 feet in thickness. The formation unconformably overlies the Mancos Shale, the Fruitland Formation and Kirtland Shale undivided, and the unnamed Upper Cretaceous volcanic unit on a surface of very low relief (fig. 2), The Telluride is gradationally overlain by the San Juan Formation of middle and late Tertlary age. The rocks in the conglomerate are rounded pebbles and cobbles consisting of a variety of igneous, metamorphic, and sedimentary types in a sandy calcite-cemented matrix. The unit includes some material from the unnamed Upper Cretaceous volcanic unit. Volcanic debris has not been reported from the Telluride Conglomerate elsewhere. The source of the conglomerate probably was to the east or southeast.

The Telluride Conglomerate has not been recognized north of the Cimarron Ridge, but it may have extended over much if not all the Cerro 
Summit quadrangle. No fossils were found in the Telluride and the actual age is unknown. Cross and Larsen (1935, p. 47) assignied an Oligocene(?) age on the basis of stratigraphic relationships in the San Juan Mountains.

\section{SAN JUAN FORMATION}

The San Juan Formation (Luedke and Burbank, 1964) crops out as a thick cliff- and slope-forming unit along Cimarron Ridge and over a wide area to the south and east of Cimarron Ridge. The formation consists of interbedded volcanic conglomerates, laharic breccias, and flows and flow breccias. Some granitic boulders and cobbles similar to those In the Telluride Conglomerate occur locally in the formation. The composition of the volcanic materlals is rhyodacitic to quartz latitic (Luedke and Burbank, 1964, p. 39). The San Juan Formation of Cimarron Ridge 1s the distal part of a large fanglomerate deposited on the flank of the rapidly rising middle and late Tertiary volcanic San Juan Mountains. The formation thins northward from more than 3,000 feet near Ouray (Luedke and Burbank, 1964, p. 41) to about 600 feet near the norch end of Cimarron Ridge. The thinning seems to be in part a depositional feature and in part the result of erosion prior to the deposition of the overlying Potosi Volcanic Group.

Along Cimarron Ridge, the San Juan Formation gradationally overIles the Telluride Conglomerate and is unconformably overlain by welded tuff of the Potosi Volcanic Group. 


\section{POTOSI VOLCANIC GROUP}

Interbedded welded tuffs and tuffaceous conglomerates of the

Potosi Volcanic Group crop out as a cliff-forming unit that is preserved in erosional remnants along Cimarron Ridge. Locally, as many as three separate welded tuff units are present and at one locality a tuffaceous conglomerate was noted between two of the units. The combined thickness of the welded tuff and tuffaceous conglomerate is as much as 270 feet.

A small patch occurs just east of the quadrangle boundary

(W. R. Hansen, oral commun., 1964) and probably one or more of the units formerly extended over the quadrangle. Much of the landslide debris of the quadrangle is characterized by large boulders of welded tuff derived from the Potosi.

The Potosi rocks appear to be the youngest of the Tertiary volcanic units that were deposited in the area of the quadrangle. Younger volcanics occur in the area to the south, but there is no evidence that any of the younger units extended as far north as the north end of Cimarron Ridge. The age of the Potosi Volcanic Group is cons1dered to be middle and late Tertiary (Luedke and Burbank, 1964, P. 39).

\section{Tertiary Rocks}

CONGLOMERATE ON POVERTY MESA

The only rock of definite Tertiary age that crops out in the Cerro Sumit quadrangle is some conglomerate and tuff breccia which occurs in two small areas on Poverty Mesa in the northeastern part of 
the area. In adjacent areas the conglomerate is overlain by the Potos 1 Volcanic Group. The conglomerate and tuff breccia unit is poorly exposed and the character of the unit is not well known. Atwood and Mather (1932, p. 102) considered the conglomerate to be till. The unit seams to consiat of conglomerate composed of woll-rounded boulders and cobbles and, locally near the base of the unit, gray-green tuff breccia. The unit forms rounded hills that are brush and tree covered; the character of the conglomerate is determined from rocks exposed on the slopes and the tuff breccia is exposed near the east boundary of the quadrangle in a shallow roadcut.

The tuff breccia is probably of intermediate composition and Is composed of volcanic debris in a tuffaceous matrix. The tuff breccia Is similar to materials in the West Elk Breccia and the San Juan Formation, although the rock seems to be more like that in the West Elk. The boulders of the conglomerate, which are as much as 2 feet in diameter, Include a variety of igneous, metamorphic, and sedimentary rock types, the source of which is largely unknown. Rock types identical to those in the conglomerate on Poverty Mesa are present in the West Elk Breccla on the north side of the Black Canyon (W. R. Hansen, oral commun., 1961) and in the Telluride Conglomerate and the San Juan Formation in the Cimarron Ridge area. The conglomerate on Poverty Mesa Is considered to be Tertiary in age on the basis of rock-type similarity with nearby Tertiary formations, but a more precise age must be deferred until the age and correlation of the various nearby volcanic formations and related conglomerates can be worked out. 
The contact of the conglomerate and the associated tuff breccia with the underlying Wanakah Formation, and possibly with the Precambrian, was not seen; it is inferred to be at a change in slope. The conglomerate is overlain by welded tuff of the Potosi Volcanic Group just east of the quadrangle boundary (W. R. Hansen, oral commun., 1964).

\section{Tertiary or Quaternary Rocks}

GRAVEL ALONG POOL GULCH

Stream-deposited gravel occurs in a low ridgelike hill along the southwest side of the upper reaches of Pool Gulch in the northeastern part of the Cerro Summit quadrangle. The deposit is obscured by brush and can be described only from boulders and cobbles that occur on the hill slopes. These rocks consist mostly of well-rounded cobbles, 3-6 inches in diameter, with some large rounded boulders and a few angular blocks as much as 4 feet in diameter. The cobbles are mostly igneous and metamorphic rock types that, in general, are similar to the rock types in the conglomerate on Poverty Mesa, but some are of unknown origin. The larger blocks are derived from the Potosi Volcanic Group. Pool Gulch is an abandoned stream channel, the main part of which is a narrow canyon cut into Precambrian rocks to a depth of about 1,000 feet. The headward projection of the abandoned stream channel is toward the valley of Cimarron Creek and thus Pool Gulch was probably the valley through which the ancestral Cimarron Creek passed on its way to the Gunnison River. The head of the abandoned valley $(8,600$ feet) In sec. 35, T. 49 N., R. 7 W., is now perched about 800 feet above the 
drainage divide at Cerro Sumit and is about 2,800 feet above the present Uncompahgre River and 1,700 feet above the present Cimarron Creek. The gravel along the headward reach of Pool Gulch appears to be channel fill deposited by the stream that cut Pool Gulch before the headwaters were diverted.

Fossils were not found in the gravel along Pool Gulch and efther a late Tertlary or Quaternary age may be inferred from the topographic position of the valley in relation to the Gunnison River. The gradient of a profile drawn down the bottom of Pool Gulch to the Gunnison River is between 150 and 200 feet per mile in the headward reach of the valley. Approaching the Gunnison River, the profile steepens rapidly and then drops off precipitously near the river. If it can be assumed that the stream that cut Pool Gulch was able to maintain a fairly constant gradient to the Gunnison River, then the Gunnison River was probably between 800 . and 1,200 feet higher when Pool Gulch was cut than it is today. W. R. Hansen (written commun., 1964), in mapping the Black Canyon area, has concluded on the basis of steep inner-canyon profiles, that the Gunnison River incised its canyon from 200 to as much as 800 feet during Pleistocene time. The diversion of the headwaters of Pool Gulch would, therefore; have occurred in Tertiary time if the Gunnison River was between 800 and 1,200 feet higher when the headwaters were diverted.

A possible Quaternary age for the gravel can be inferred from evidence present in the Bostwick-Shinn Park area in the northwestern part of the quadrangle. In a following section on the valley-fill 
deposits of Bostwick-Shinn Park it is shown that a sizable stream, which flowed through the Bostwick-Shinn Park valley to the Gunnison River in Cedar Ridge (Kansan?) time, deposited a coarse gravel along its course. A profile drawn on the stream gravel projects down the valley to about 1,200 to 1,200 feet above the present Gunnison River. This sugsests that the Gunnison River may have cut down 1,100-1,200 feet since Cedar Ridge time. If the Gunnison River incised its course in the Black Canyon at a fairly uniform rate, the Gunnison could have been between 800 and 1,200 feet higher in the vicinity of Pool Gulch during Pleistocene time and the gravel along Pool Gulch could be of Pleistocene age. .

\section{OLDER IANDSLIDE DEPOSIT ON WATERDOG PEAK}

0lder landslide debris, about 100 feet thick, crops out in a recent landslide scarp on the south-facing side of Waterdog Peak, a small prominence on the ridge that extends along the south border of the quadrangle. Waterdog Peak is a small hill, pyramidal in shape, composed of older landslide debris which projects through and is surrounded by more recent 1 andslide debris that has been partly derived from the older landslide material in the peak. Debris associated with the recent landsliding obscures the lower part of the deposit and the contact of the older landslide debris with underlying rocks is not exposed. The north- and east-facing slopes of Waterdog Peak are also landslide scarps, but are brush and tree covered. The west-facing slope is a surface formed by solifluction processes.

The material in the peak consists mainly of yellowish-gray heterogeneously mixed cobbles and boulders in a sandy clay matrix. The 
material includes debris from the Fruitland Formation, the San Juan Formation, the Telluride Conglomerate, and the Potosi Volcanic Group. Some debris from the unnamed Upper Cretaceous volcanic unit that occurs In the Cimarron Ridge area may also be present, but rock types in this unit are difficult to distinguish from those in the San Juan Formation, and no effort was made to differentiate the rocks of the two formations In the Waterdog Peak deposit. Debris from the various rock units occurs In the deposit in various stages of disintegration. Large boulders of cemented Telluride Conglomerate and scattered cobbles and boulders derived from the conglomerate are present.. Large boulders and slabs of welded tuff from the Potosi are mostly angular and show little evidence of rounding by transport.

Yellow sandstone and green shale masses that contrast with the yellowish-gray color of the rest of the deposit occur locally in the landslide. The detailed composition of the yellow sandstone and green shale indicates the complexity of the deposit. A well-cemented mass of yellow sandstone, about 8 feet in diameter, which crops out near the top of the peak, contains cobbles and lenses of debris from the Tertiary conglomerate and broken fragments of sandy ferruginous concretions scattered through it. The sandstone is similar to that in the Fruitland Formation. A lens-shaped mass that is mainly green shale, about 6 feet thick and some tens of feet long, crops out in the lower part of the slump scarp (this part of the exposure may actually be part of the recently slumped material). Close examination of this shale shows that It also has cobbles from the Tertiary conglomerates scattered through 
it. In addition, the shale has a sheated appearance and numerous randomly oriented slickensided surfaces are present. The manner in which younger extraneous materials can become scattered through blocks and masses of sandstone and shale is difficult to explain by normal depasition. In the writer's opinion, the extraneous materials were emplaced by the dymamic action of earthflow movement.

Atwood and Mather (1932, pl. 1) included the older landslide material of Waterdog Peak with their Cerro Till, which supposedly mantled much of the Cerro Summit quadrangle. As previously stated, the deposit projects through and contributed material to the landside debris that surrounds the peak. The older landslide debris which caps the peak is, therefore, not of the same origin as the nearby debris that Atwood and Mather mapped as Cerro Till. This does not, however, eliminate the possibility that the deposit is an ancient till. The deposit lacks sorting and stratification and includes a few striated stones. The lack of sorting and stratification is common to both till and mass-wasting debris. The roundness of the boulders and cobbles in the deposit is mostly like that in the parent rock and shows no evidence of additional rounding due to transportation.

Only a few striated stones are present in the deposit at Waterdog Peak and the striations cannot be definitely attributed to glacial action. The striations on one oblate boulder, about 1 foot in diameter, are randomly oriented, deep, rough, and jagged, unlike glacial striae, but the differences are not easily defined or measured. Flint (1947, P. 66) concluded that striations can be produced by any heavy 
mass flowing according to fluid dynamics and that reasonable evidence of glacial origin must be determined before a striation is interpreted as glacial. The striated stones in the Waterdog Peak deposit, therefore, indicate only that the material has flowed.

Howe (1909, p. 16), in his discussion of older landslide deposits in the San Juan Mountains area, concluded that "strict geologic evidence $* *$ that is, the condition and character of the material and its relation to rock in place," must be used to differentiate older landslide from glacial debris. The internal character of the debris in Waterdog Peak is more characteristic of landslide debris than till, and the debris has been mapped as such.

The debris in Waterdog Peak is topographically isolated, and it is difficult to tell how the material was transported to its present position. The material resembles rubble that is presently accumulating along the flanks of Cimarron Ridge below the San Juan Formation, but the striated stones and the sandstone and shale masses indicate that the material has flowed. The deposit is in an area in which a hypothetical detachment fault was mapped (pI. 1). The detachment fault is based on discordant attitudes of the bedrock along the ridge west of Waterdog Peak. The older landslide debris on Waterdog Peak could have accumulated in place after the detachment faulting, or it could be landslide debris that was moved to its present position when the detachment faulting occurred. 
Quaternary Rocks

Quaternary deposits in the Cerro Summit quadrangle include the following informal units: landslide deposits, older stream gravel of Shinn Park, valley-fill deposits of Bostwick-Shinn Rark, pediment deposits, eolian deposits, and alluvial and colluvial deposits.

\section{LANDSLIDE DEPOSITS}

\section{Introduction}

Much of the Cerro Summit area is mantled by hummocky boulderstrewn surficial debris that has long been considered to be till. The debris was first described as till by Hills (1884, p. 42). Atwood (1915, P. 14) established the type locality of the Cerro Till at Cerro Sumit. Later, Atwood and Mather (1932, p. 102) described the debris at Cerro Sumit as a "heterogeneous mixture of various materials rangIng in size from the finest rock flour to boulders 25 feet in length-a typical glacial till." The Cerro Till, as mapped by Atwood and Mather (1932, pl. 1), covers a large semicontinuous area from Poverty Mesa southward for about 20 miles along the west flank of Cimarron Ridge. Several small areas which were also mapped as Cerro Till occur along the north and west flanks of the San Juan Mountains and east of Pagosa Springs on the southwest flank of the San Juan Mountains. Detailed mapping by the writer (Dickinson, 1965) has shown that the debris mapped in the Cerro Sumnit quadrangle and along the west flank of Cimarron Ridge by Atwood and Mather (1932) as Cerro T111 is landslide debris, and the name Cerro $\mathrm{T} 111$ has been abandoned. This 
does not imply that all the material previously mapped as Cerro Till in the area of the San Juan Mountains is not till, but rather that each deposit should be re-evaluated on the basis of its local geologic setting and new names established where appropriate.

\section{Description of the Landside Deposits}

Landslide deposits cover about 85 percent of the Cerro Summit quadrangle ( 1.1 ) in an almost continuous blanket of debris over the area south of the Cimarron fault. In detail, the landslide deposits vary from recently formed simple slumps along drainages and ditches to compound features that have formed through repeated mudflow, earthflow, and slumping movements. Several of the larger flow masses, some of the more prominent slump scarps, and several small areas of apparent active landsilde movement are shown on the map.

Much of the landslide debris is a heterogeneous mixture of boulders and cobbles dispersed in a matrix of clay and crushed shale from the various bedrock formations in the area. North of Cedar Creek, the debris locally includes material from the Precambrian of Poverty Mesa, igneous, metamorphic and sedimentary debris from the Tertiary conglomerate on Poverty Mesa, and sandstone from the various Jurassic and Cretaceous formations that crop out along the cimarron fault. The most prominent rocks present in the debris of the quadrangle area are large boulders of welded tuff of the Tertiary Potosi Volcanic Group. Only small patches of the welded tuff are preserved on Poverty Mesa and the nearby Cimarron RIdge and High Mesa, but boulders of this material are scattered throughout the area. South of Cedar Creek, the Iandslide 


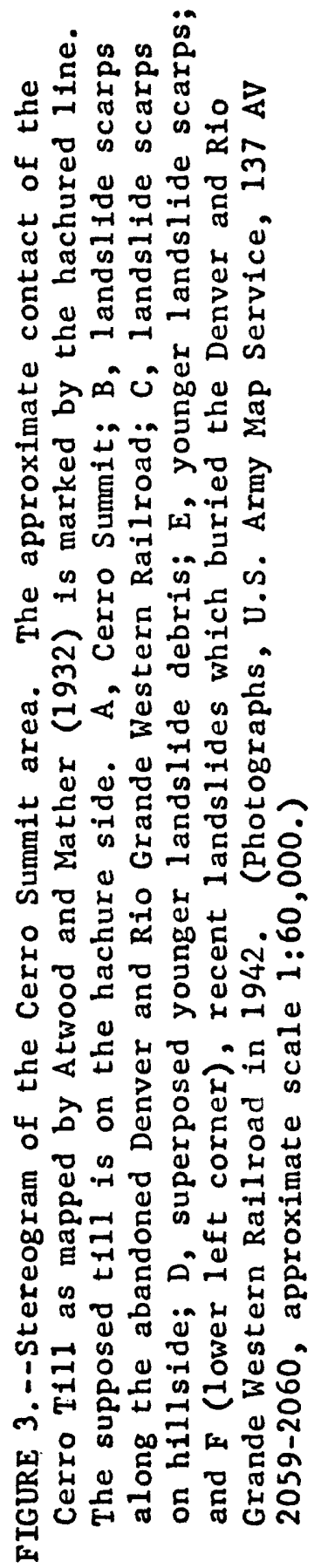


debris includes materials from the San Juan Formation, the Telluride Conglomerate, and unnamed Upper Cretaceous volcanic rocks, but none from the Jurassic formations. Locally, the bouldery debris is thin to absent and the landslide consists of local bedrock material that has moved. The thickness of the debris is extremely variable in the area and locally is 200-300 feet thick.

The landslide debris can usually be distinguished by a hummocky topographic expression and a distinctively mottled vegetational pattern on aerial photographs. From the ground, however, the character of the deposits is not always apparent.

Deposits typical in structural and lithologic features of those in the Cerro Summit area are well exposed in the highway cut at Cerro Sumit. This cut is about 55 feet deep through the middle of an elongate hill that joins the Irregular sloping surface to the south with the hilly area to the north (fig. 3). The well-exposed material in the western part of the highway cut seems, on casual observation, to be entirely undisturbed Mancos Shale. Careful examination shows that the shale does not have regular bedding and that stringers of crushed shale cut across the bedding in the outcrop.

In the eastern part of the highway cut the deposit consists of bouldery debris in the upper 5 to 10 feet, intermixed bouldery debris and crushed shale in a middle zone; and badly crushed Mancos Shale in the lower part. The bouldery debris in the upper part of the cut has a matrix of sandy clay derived in part from fresh Mancos Shale and in part from weathered bedrock. The boulders, of locally derived types, 


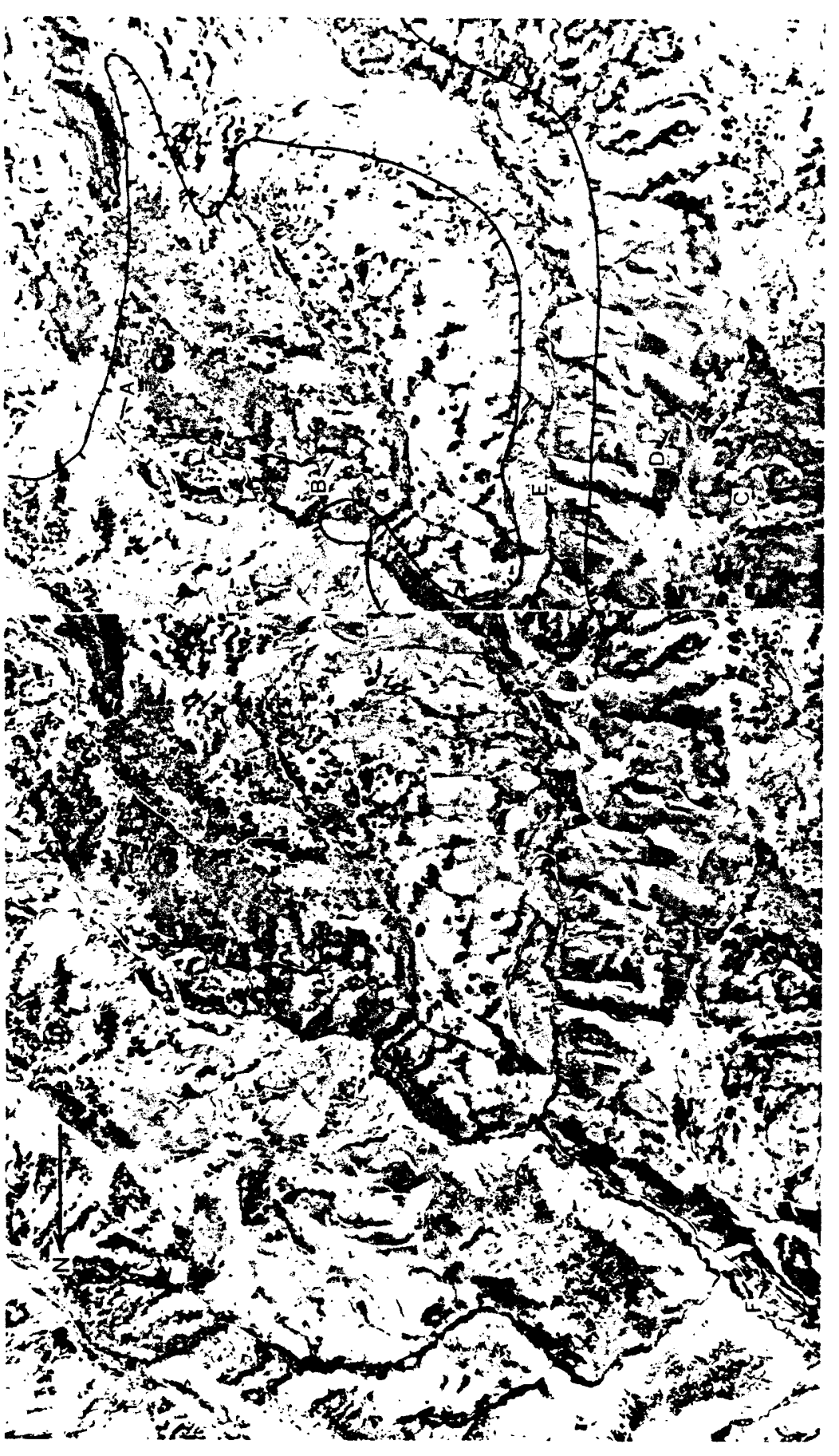


are mostly rounded porphyritic volcanic and granitic rocks, 6 inches to 2 feet in diameter. Some larger angular boulders, as much as 4 feet in diameter, consist of welded tuff derived from the Potosi Volcanic Group. The wide distribution of large boulders of Potosi welded tuff, which are present throughout the surficial deposits in the Cerro Summit area and locally scattered over a widespread area of the Mancos Shale northeast of Montrose, probably indicates that the original extent of Potosi welded tuff was greater than is shown by present outcrops (W. R. Hansen, written commun., 1964). Most of the other rock types in the bouldery debris occur in the Tertiary conglomerates on Poverty Mesa and in Cimarron Ridge. Poorly defined crude scratches or striations that could be mistaken for glacial striations occur on a few of the smaller rounded boulders. - Similar scratches, however, can be found on boulders in undoubted landslide deposits elsewhere in the area. Flint (1947, p. 66) concluded that striations on stones can be produced by any heavy mass flowing according to fluid dynamics and that reasonable evidence of glacial origin must be determined before a striation is interpreted as glacial. The hypothesis that the bouders were transported to Cerro Summit by a glacier (Atwood and Mather, 1932, p. 82) is thus no longer required to explain the character of the surficial materials.

The mode of emplacement of the bouldery debris at the top of the highway cut at Cerro Sumit is not readily determined from exposures or from topographic expression as shown on aerial photographs (fig. 3). The hill at Cerro Summit is rounded and otherwise expressionless. The 
debris covering the hill supports vegetation, consisting mostly of sagebrush, oak bush, and serviceberry, that has a distinctively mottled pattern similar to that on landslide deposits elsewhere in the area. As exposed in the highway cut, the hill seems to consist mainly of broken and crushed shale with some bouldery material on the ourface. The hill has probably been eroded from landslide debris. The bouldery debris could be part of the original landslide debris or could have been emplaced by landslide and creep prior to erosion of the hill to its present shape.

Features similar to those in the highway cut at Cerro Summit occur in most of the highway cuts both east and west of Cerro Summit. Locally, the slickensided surface over which the landslide debris moved is exposed. Shale that is seemingly undisturbed except for minor crumpl fing or folding overlies bouldery debris in a roadcut just east of the quadrangle boundary. In this area sparse bouldery debris occurs at the surface and $1 t$ would be difficult to determine from the ground that the area was not bedrock were it not for the roadcut. The slightly hummocky surface and mottled vegetational pattern that indicate the landslide character are clearly indicated on aerlal photographs of the area.

Many landsilde scarps west of Cerro Sumit that occur in debris mapped as Cerro Till by Atwood and Mather (1932) are evident in aerial photographs. These scarps and the associated humocky landslide debris below the scarps occur both on the upland hillsides (fig. 3, 10c. C, D) and along the valley sides (fig. 3, loc. B, E, F). That landsliding 
has occurred at various times is shown by crosscutting scarps that are sharper and fresher (fig. 3, loc. E) in appearance than others in the area. The landsliding along the valleys occurred after the valleys were cut. Geologic study by the writer in the Bostwick Park area, 5 miles northwest of Cerro Sumit, indicates that most of the downcutting along Cedar Creek occurred during post-Bull Lake time.

A large hummocky tongue-shaped earthflow mass, which occurs just south of the quadrangle, has many features that are typical of the large landslides within the quadrangle. The lobe has poorly defined boundaries and is largely covered by trees and brush. The lobe includes an area of more than 3 square miles and is difficult to recognize as such on the ground. On aerial photographs (fig. 4), however, the landslide lobe is readily identified.

The landsiide debris along the west side of Shinn Park, which was also mapped as Cerro Till by Atwood and Mather (1932), is of interest because of its geomorphic implications. The debris is similar in composition to that along the east side of Shinn Park, but must have come from a hilly area to the west that was eroded away after the landsliding occurred. The hilly area formed the divide between the Uncompahgre River valley and the drainage that flowed through Bostwick and Shinn Parks, but the area now is part of the Uncompahgre River valley and is several hundred feet lower than the landside debris along Shinn Park.

The landslide lobe in the middle of secs. 28 and 29, T. $49 \mathrm{~N} .$, R. 7 W., was mapped by Hunter (1925) as Precambrian bedrock. The 


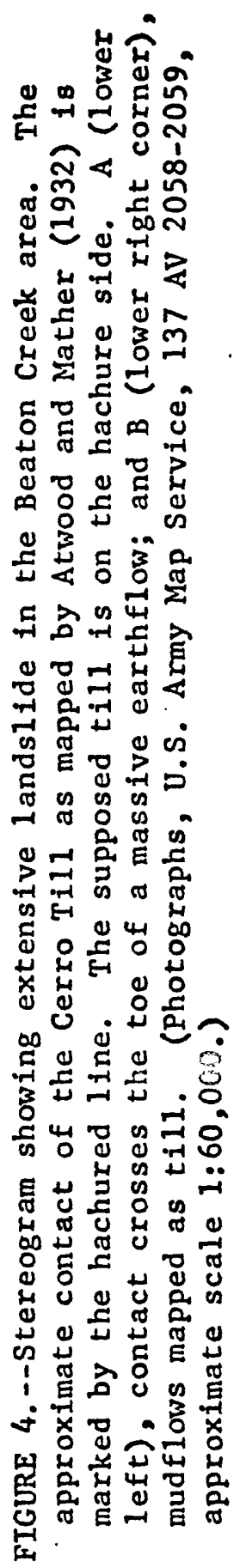




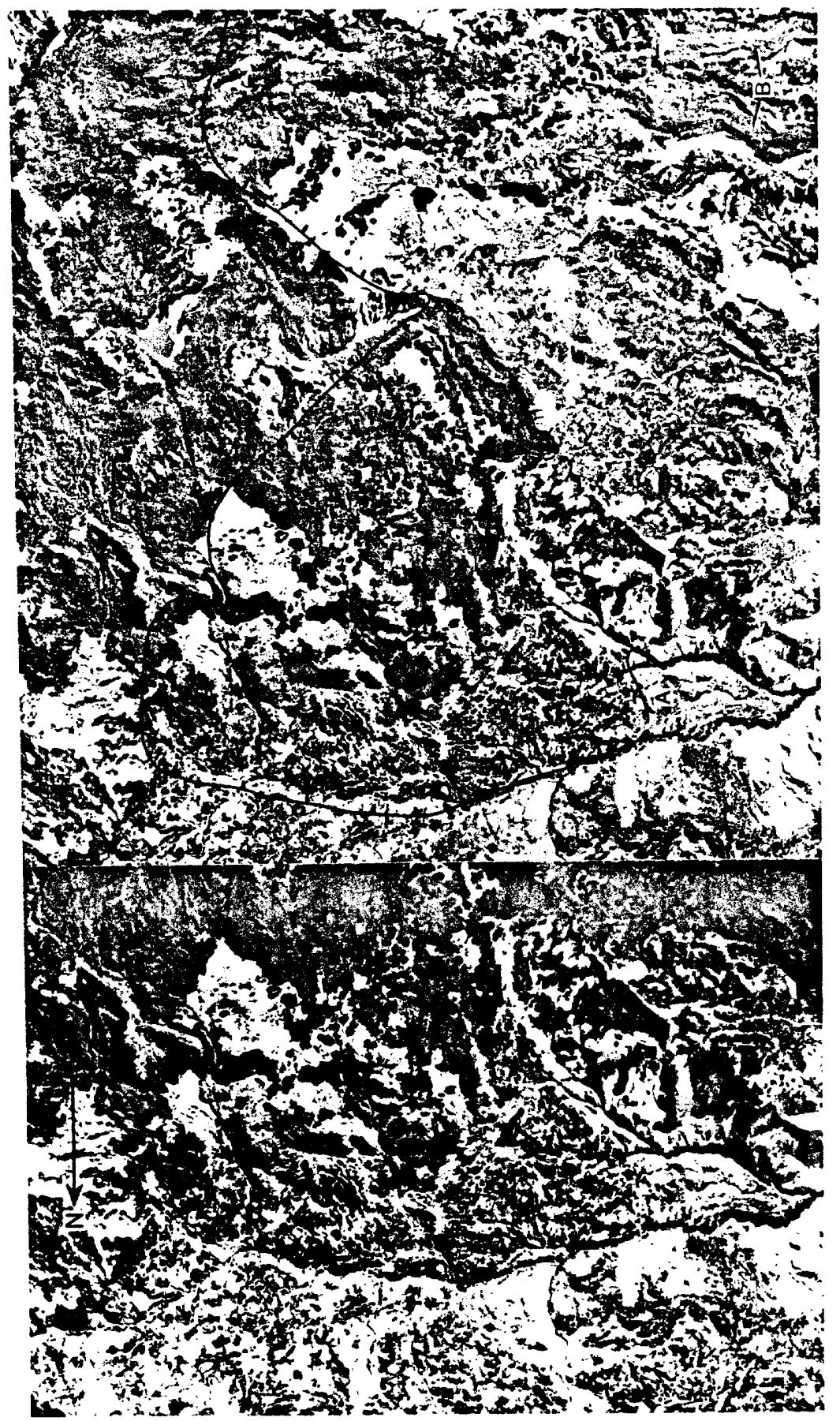


material in the hill formed by the lobe is entirely Precambrian rock and is difficult to distinguish from actual bedrock because the Precambrian bedrock is usually mantled by slope debris of similar appearance. Locally in the landslide mass, small pegmatite bodies crop out in much tha ome manner as those north of the Cimarxon fault. A pile of olivine-gabbro boulders and weathered gabbro debris that Hunter mapped as a small intrusive occurs near the upper end of the lobe-shaped mass. Hunter apparently did not notice two small gabbro intrusives just north of the Cimarron fault. One intrusive is immediately above the landslide debris and the outcrop is mostly free of weathered debris. The gabbro outcrop to the west, however, is intensely weathered material. The gabbro outcrop on the upper end of the landslide debris, therefore, appears to be the sheared-off upper part of the gabbro intrusive that occurs on the hillside above. Apparently, the landslide occurred as a large sliding mass in which much of the Precambrian rock moved without being greatly disturbed.

Perhaps the most easily identified landslides are those that are currently active. A group of landslides (fig. 5) that have been active since 1941 (Varnes, 1949, p. 3) occurs along Cedar Creek at the northeast edge of Shinn Park. According to Varnes, large blocks broke from the cliffs in 1942 and buried about 1,000 feet of the Denver and Rio Grande Western Railroad track that was never recovered. The Cedar Creek landslides are compound features. The upper part is in the form of large slump blocks that have broken from the cliffs and dropped down 50-75 feet, forming a series of benches consisting of blocks of Mancos 


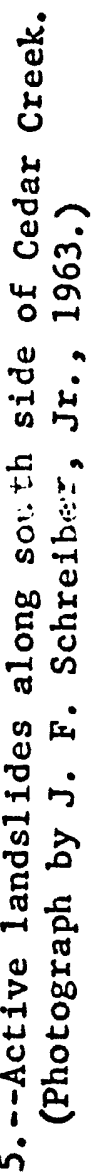

留

$64 a$ 


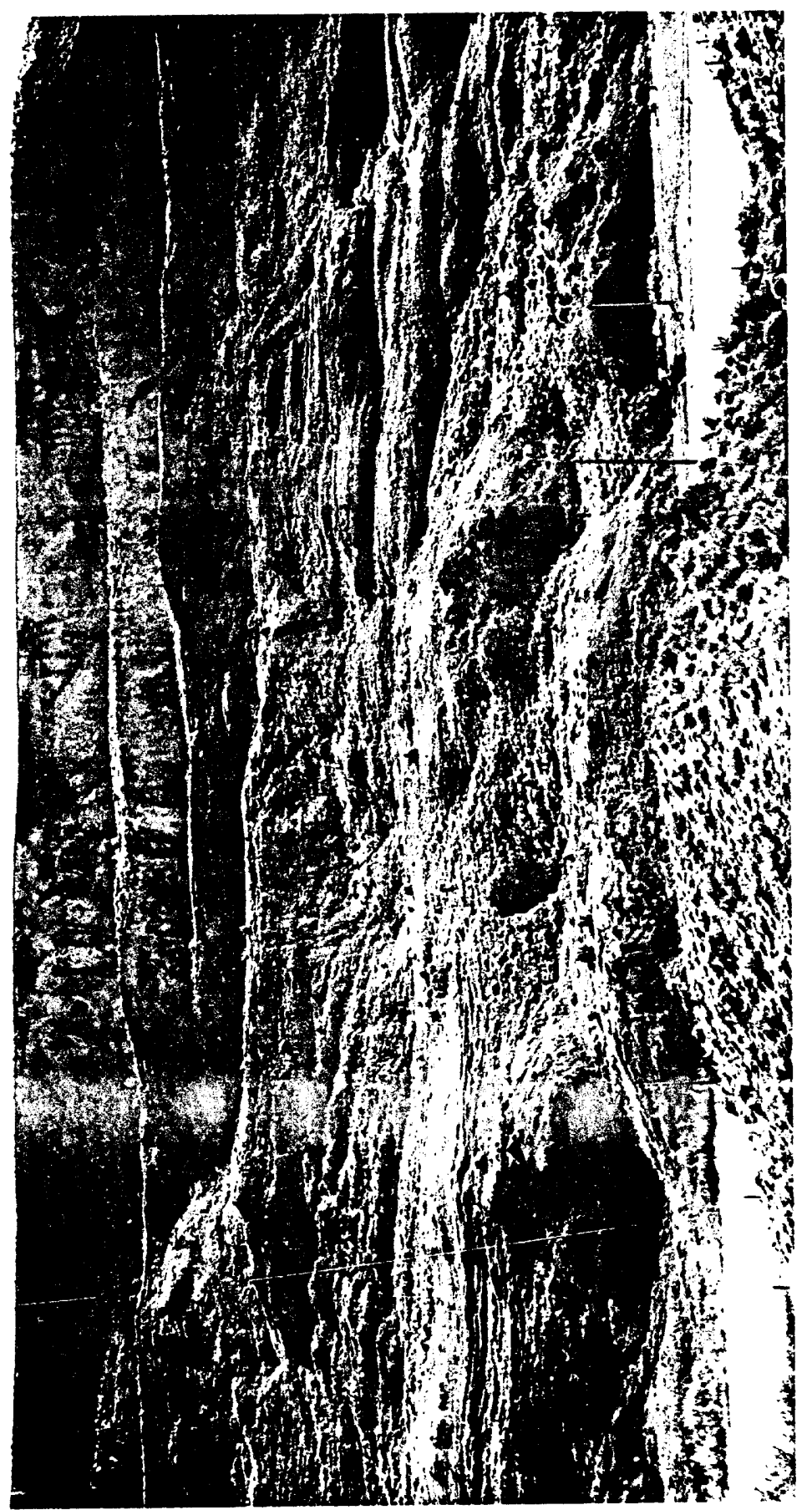


Shale capped with alluvium. Below the benches, the debris has disintegrated into earthflow material. Locally, lateral ridges have formed along the sides of Individual masses and, where movement continues, freshly broken material forms a small furrow along the crest of the ridge. These lateral ridges are characteristic of this type of earthflow movement and can be seen in the form of high sinuous ridges paralleling larger landslides in the Cerro Sumit area. The active landslides along Cedar Creek appear to be the result of irrigation water collecting in the gravels at the base of the alluvium that fills the valley of Shinn Park. The water drains northward along the gentle dip of the gravel-shale interface to the cliffs along Cedar Creek where small springs form. When the Mancos Shale becomes sufficiently permeated with moisture, it loses its stability and flows or forms slump blocks, depending on the steepness of the slopes. The continual addition of water to the slumped debris along Cedar Creek by irrigation water seeping out from the gravel tends to perpetuate the landslide movements.

The age of most of the inactive landslides in the Cerro Sumwit: area is difficult to determine because there are few datable geomorphic features to which the landsildes can be related. No fossils which would indicate the age of the debris have been found, and only a few cuts allow inspection of the soil profile present. Locally, a thick caliche capping on the deposits suggests that many are pre-Bull Lake in age. In many places, however, creep has destroyed any soil profile that may have formed. Landsliding has probably been occurring in the 
area since some time in the middle to late Tertiary when erosion first began to dissect the poorly consolidated volcanic rocks that probably covered much of the area. The landslide deposits may in part be as old, or older than the older stream gravel of Shinn Park. Rapid downcutting occurred in the area during the Quaternary Period and oversteepened slopes have probably been present during much of the Quaternary. During periods when the molsture was greater than that generally available during the Recent, the soft Upper Cretaceous sandstones and shales become unstable and massive landslides formed. Locally, landsliding continues to occur where sufficient moisture is present.

\section{OLDER STREAM GRAVEL OF SHINN PARK}

Along the west side of Shinn Park, 20-30 feet of coarse stream gravel occurs at or near the tops of two small hills. The gravel consists mostly of well-rounded boulders and cobbles of various porphyritic volcanic-rock types. Some of the boulders are as much as 4 feet in diameter. The gravel in the two small outcrops appears to have been deposited by a stream, possibly the ancestral Cow Creek, that flowed northward to the Gunnison River through a valley parallel with the Bostwick-Shinn Park valleys but about 300 feet higher. The two small gravel deposits and a similar one that caps a hill about 700 feet north of the quadrangle in sec. 23, T. 49 N., R. 8 W., are the only vestiges of the former higher valley level that remain. Fossils were not found, but the deposits must be as old as early Pleistocene because middle and upper Pleistocene sediments occur in the younger valley-fill deposits of Bostwick-Shinn Park. The older stream gravel may have been deposited 
by melt waters from glaclers during Washakie Point (Nebraskan?) time (table 4).

VALLEY-FIII DEPOSITS OF BOSTWICK-SHINN PARK

Alluvium, colluvium, and volcanic ash, all of Pleistocene age, crop out in the Upper Bostwick Park and Shinn Park areas in the northwestern part of the Cerro Summit quadrangle. The deposits are an aggradational sequence of sediments that were deposited in a valley cut by a stream presumed to have headed in the San Juan Mountains. The stream flowed northward across the west side of the quadrangle to the vicinity of Upper Bostwick Park where it. turned to the northwest and Elowed through Red Rock Canyon to join the Gunnison River. Erosion has apparently destroyed vestiges of the former valley south of Shinn Park, and the headward erosion of Cedar Creek has divided the northern extent of valley into two parts: Shinn Park on the south and Bostwick Park on the north.

Several soll profiles and locally three volcanic-ash beds form stratigraphic markers within the sediments. The deposits are expose in the floor of the parks, in steep slopes and scarps along Cedar Creek and its tributary drainages, and locally along the south and west sides of the parks. Atwood and Mather (1932, p. 114) correlated these deposits with the Florida Gravel, but the writer's study indicates that the deposits are dissimilar in age and environment of deposition to the type Florida Gravel. In this report the deposits are referred to as the valley-fill deposits of Bostwick-Shinn Park. 
Description of the Deposits

The valley-fill deposits accumulated in an asymmetrically shaped valley (Pl. I, sec. B-B') with the west and south side of the valley being steeper than the east and north side. The sediments, 0-350 feet thick, consist of coarse otream gravel in the bottom of the valley overlain by alluvium and colluvium of local derivation. They unconformably overlie the Mancos Shale and are locally overlain by landslide debris. The deposits of the Shinn Park area are generally thinner, contain fewer good marker horizons, and cannot be as easily studied as the deposits in the Bostwick area.

The most complete and well-exposed outcrop of the valley-fill

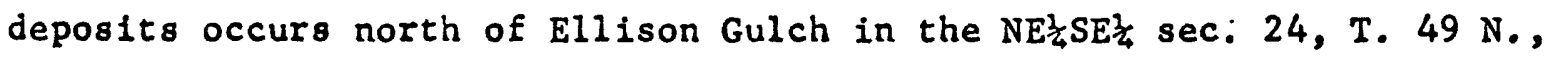
R. 8 W. (field locality 910, pl. 1; figs. 6 and 7). In this area, a steep arcuate escarpment trends normal to the direction along which drainage flowed through the old Bostwick-Shinn Park valley. The sediments exposed in this area were deposited near the center of the old valley under optimum conditions for preservation.

The deposits exposed in the Ellison Gulch area have been divided into five stratigraphic units (fig. 7). The divisions are based in part on Iithologic variations and in part on the writer's interpretation of the several soil profiles. Laterally, toward the valley sides, the units thin and cannot be separated. The following 18 a generalized description of the deposits exposed near field locality 910.

Unit I, the basal deposit, consists of as much as 120 feet of coarse well-rounded gray stream gravel with boulders as much as 1 foot 


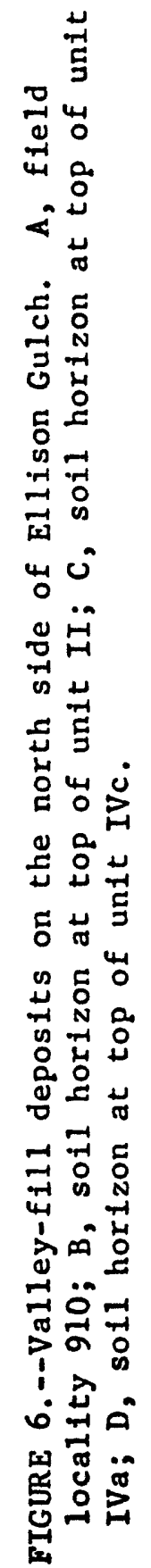

$69 a$ 


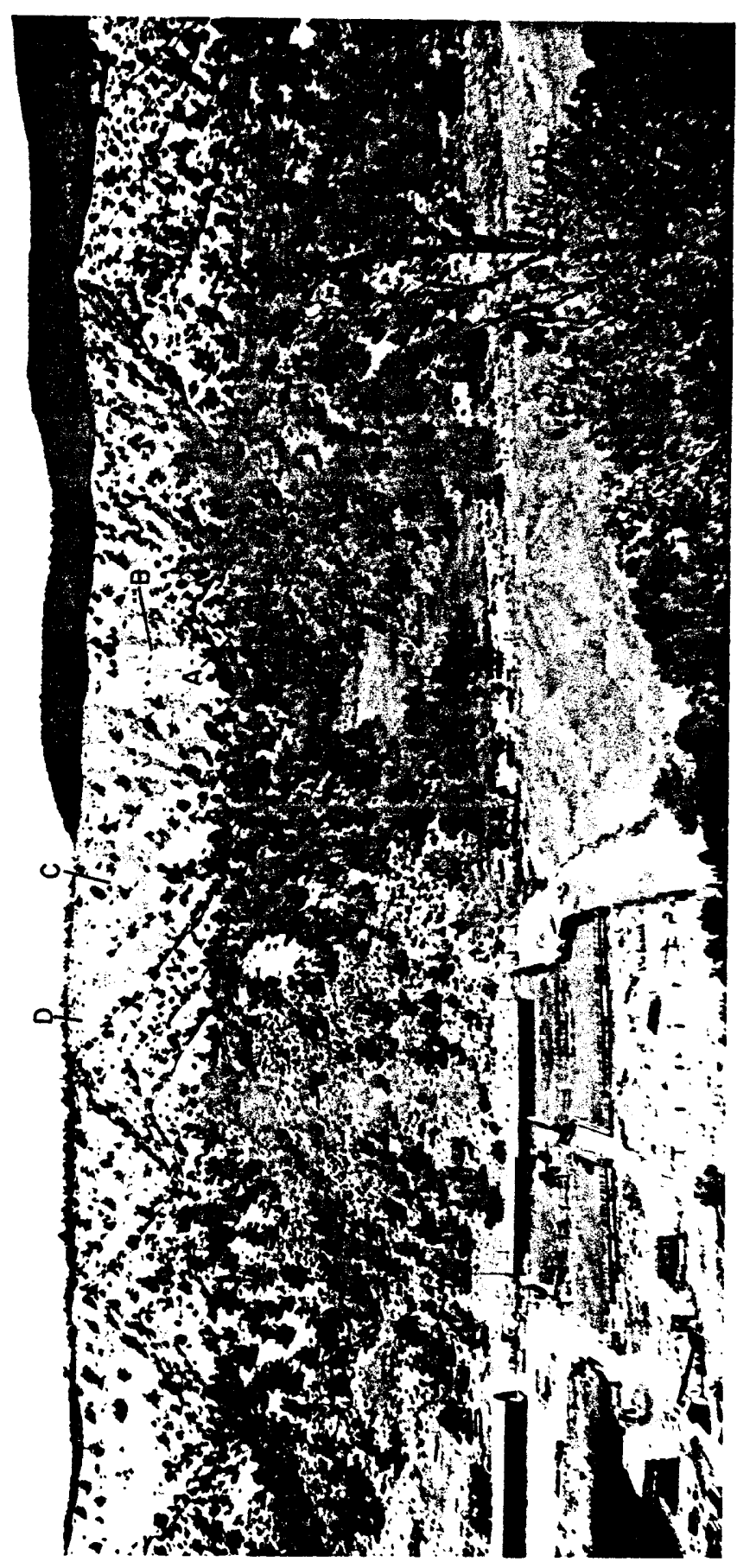




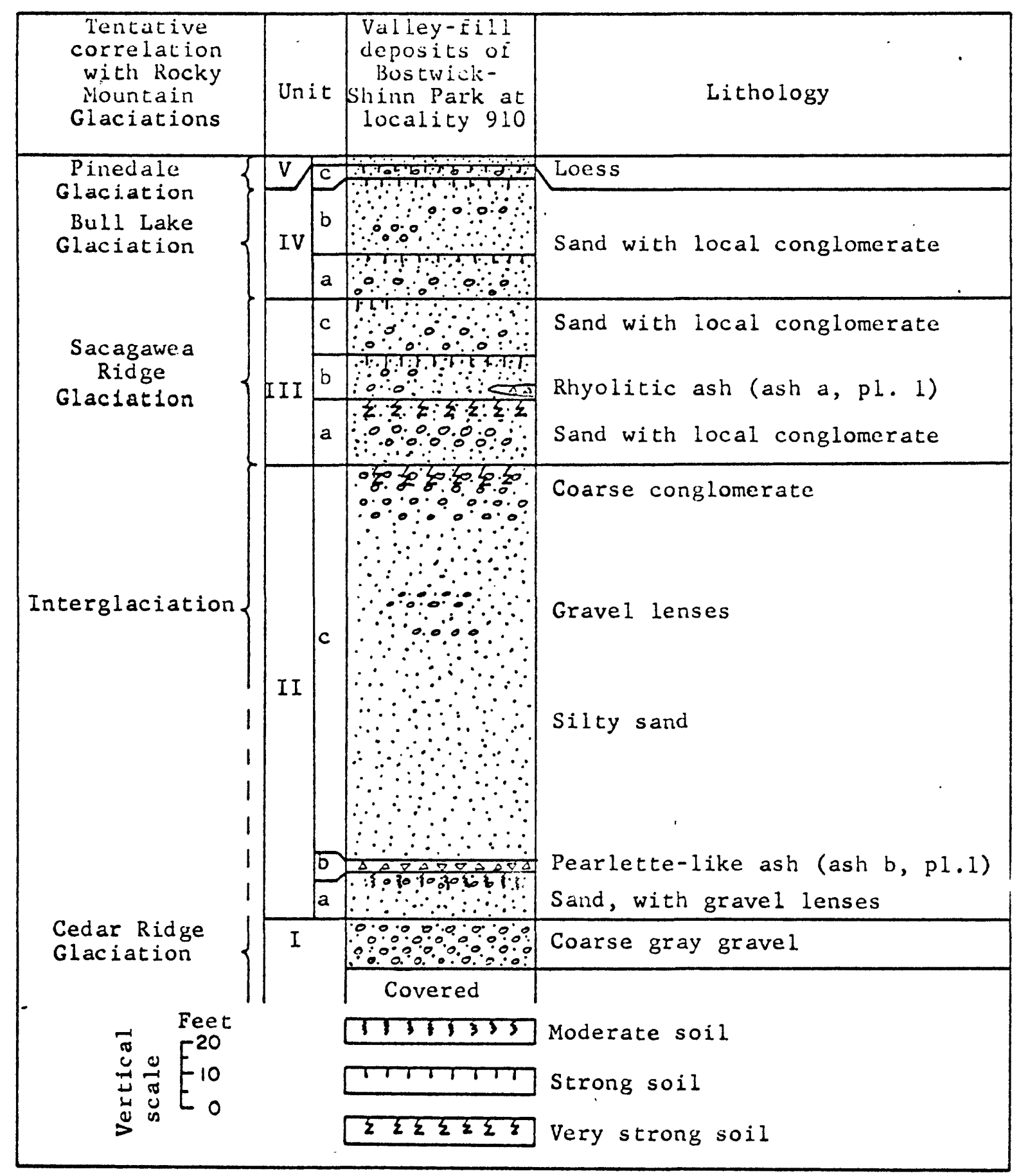

FIGURE 7.--Generalized stratigraphic section of valley-fill deposits of Bostwick-Shinn Park at field locality 910. 
in diameter. The massively bedded poorly sorted gravel has a sandy matrix and contains sparse lenses of pebbly sand. The clasts are predominantly porphyritic volcanic rocks but include some vein quartz and concretionary Iimestone. The IImestone clasts are probably from the Mancos Shale and the other rocks are from a partly mineralized volcanic terrain, presumably the Tertiary San Juan Mountains. Throughout the area, unit I seems to be overlain by alluvial and colluvial deposits (unit IIa) that consist of locally derived materials. This suggests that the river which cut the Bostwick-Shinn Park valley and deposited the gravel of unit I had ceased to flow through the valley when the sediments of unit IIa were deposited. The age of the gravel 1s Pleistocene (G. E. Lewis, written commun., 1964), as indicated by an

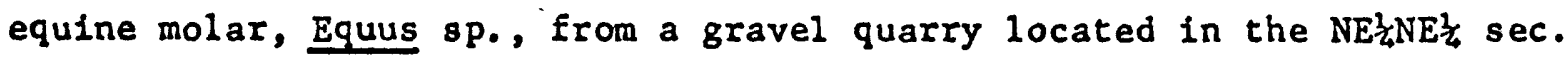
23, T. 49 N., R. 8 W., just north of the quadrangle boundary. The molar was collected by Alvin Strand of Montrose, Colorado, and identified by Lewis.

Unit II consists of about 135 feet of 11ght-brown to grayishorange sand containing scattered gravel lenses. The unit has been divided into three parts based on lithologic variations.

At field locality 910, unit IIa, the lower part, includes about 15 feet of light-brown sand, silty, and clay. Lenses of conglomerates with clasts as much as 3 inches in diameter occur in the upper part. A moderatiely developed brown soil having a B horizon 12 inches thick and a $C_{c a}$ horizon 4 inches thick is developed on sandy alluvium at the top of the unit (fig. 6). Elsewhere in the area, unit IIa is about 
1 to 25 feet thick and is comprised of coarse alluvial gravel interbedded with sand, silt, and clay. The boulders in the gravel are poorly rounded and as much as 3 feet in diameter.

Unit IIb is about 3 feet thick and consists of 6 inches of very clean yellowish-gray rhyolitic volcanic ash, 3-9 inches of conglomerate, and about 2 feet of grayish-orange sandy and silty volcanic ash. The sand and silt become predominant upward. This volcanic-ash bed is widespread in the valley-fill deposits and is shown on the map (pl. 1) as ash $b$. The ash bed is discussed in detail in a following section on the volcanic ash beds in the valley-fill deposits.

Unit IIc consists of about 120 feet of sand, silt, and clay with local intercalated lenses of coarse bouldery colluvial gravel. At field locality 910 , about 20 feet of coarse bouldery gravel with boulders as much as 3 feet in diameter occurs at the top of the unit. The top of the unit is marked by a very strong brown soil having a B horizon 26 inches thick and a $C_{c a}$ horizon 36 inches thick. The soil is present elsewhere in the valley-fill deposits but it is similar to the soil at the top of unit IIIa and no attempt was made to identify or locate it elsewhere in the deposits.

Fossils were not found in the sediments of unit II near locality 910. Equine teeth (USGS Denver Vertebrate catalogue No. D558) were

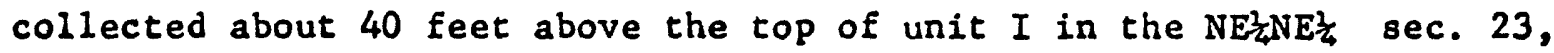
T. 49 N., R. 8 W., about 700 feet north of the quadrangle. The sediments from which the fossils were collected are near the edge of the Bostwick-Shinn Park valley and cannot be related to the sequence of 
soll profiles near field locality 910 . The fossil locality seems, however, to be in sediments equivalent to those of unit II at locality 910. According to G. E. Lewis, C. B. Schultz, and L. G. Tanner (written commun., 1963), the teeth probably represent Equus (Equus) sp. of postKansan age. Gastropods occur locally in sediments equivalent to those in which the equine remains were found but they have not been studied. Unit III, which is about 50 feet thick near field locality 910 , consists of light-brown conglomeratic alluvium and colluvium. The unit has been divided into three parts, based primarily on soil profiles. The lower part, unit IIIa, is about 20 feet thick and has a strongly developed but partly stripped brown soil at the top. The soil has a B horizon 7 inches thick and a $C_{c a}$ horizon 40 inches thick. The middle part, unit IIIb, is about 15 feet thick and has a strong soil with a B horizon 6 inches thick and a $C_{c a}$ horizon 20 inches thick at the top. Locally, lenses of rhyolitic volcanic ash (ash va on pl. 1) as much as 8 inches thick occur about 3 feet above the base of this unit. The upper part, unit IIIc, is about 15 feet thick and is disconformably overlain by the sediments of unit IV. A soil is not present at the top of unit IIIc at field locality 910, but locally a weak to moderately developed soll is preserved. The lithologic break between units III and IV is distinct. The sediments of unit III are more reddish, more calcareous, and more indurated than the sediments of unit IV. No fossils were found in unit III or in rocks believed to be equivalent to it. 
Unit IV consists of about 40 feet of light-brown bouldery alluvium. The unit has been divided into three parts separated by strong solls. The material in the divisions is generally bouldery debris in the lower part and sandy alluvium in the upper part. The lower part, unit IVa, is about 15 feet thick and the soil at the top has a B horizon 24 inches thick and a $C_{c a}$ horizon as much as 36 inches thick (fig. 6). The middle part, unit IVb, is about 20 feet thick. The soil at locality 910 is poorly preserved, but about 300 feet to the west the soil has a B horizon 18 inches thick and a $C_{c a}$ horizon 12 inches thick. Unit IVc 1s 4-6 feet thick and is disconformably overlain by the fine sand of unit V. A Cca horizon as much as 2 feet thick occurs at the top of unit IVc (fig. 6).

Unit $V$, the uppermost unit, consists of yellowish-brown finegrained eolian sand about 2 feet thick at locality 910 . About 300 feet to the west of locality 910 , unit $V$ is as much as 25 feet thick. The varlable thickness is due to erosion. A soil profile is not present at the top of the unit and no fossils were found in the unit.

\section{VOLCANIC ASH IN THE VALLEY-FILI DEPOSITS}

Three stratigraphically separate volcanic ash beds were found in the valley-fill deposits of Bostwick-Shinn Park. Volcanic vents of Plelstocene age are not known in the nearby region and the ash beds must be from eruptions which spread over a wide area. The ash beds were, therefore, studied in detail in an effort to correlate them with ashes of known stratigraphic position elsewhere. 
In the laboratory, samples of the three ash beds were studied according to techniques developed by Powers and Wilcox (1964) in differentiating late Pleistocene and Recent pumfce and ash eruptions from Mount Mazama at Crater Lake, Oregon, and Glacier Peak in the northern Cascade Range of Washington. The samples were ultrasonically scrubbed and separated into light, intermediate, and heavy fractions, using bromoform. The light fraction, which consisted primarily of glass, was further manipulated with an electromagnetic separator to produce the cleanest material possible for chemical analysis. The intermediate fraction consists of glass, quartz, feldspar, and other materials, but the components of this fraction were not considered in this study. The heavy fraction, which consists of those minerals with a specific gravity greater than 2.8 , is composed of phenocrysts indigenous to the ash and detrital heavy-mineral grains. The phenocrysts are important as distinguishing characteristics of the ash (H. A. Powers, oral commun., 1963), and, to guarantee against confusion with minerals of detrital origin, only those minerals that had the proper adherent glass were examined. Refractive indices of the glass and the indigenous heavy-mineral phenocrysts were determined by using the immersion method with central illumination and a sodium light source. "Focal masking" techniques (Wilcox, 1962) were also used. The optical properties of the phenocrysts were measured with the aid of a spindle stage (Wilcox, 1959) which enables single phenocrysts to be examined. Phenocrysts found to be completely enclosed with glass were crushed to enable index measurements on the phenocrysts themselves. 
Chemical analyses of the glass fraction were prepared by laboratories of the U.S. Geological Survey. An idea of the reproducibility of the analyses is obtained by comparison of samples 63-D-513 and 513-3 (table 5), collected by the writer from the same outcrop but at different times. Class from sample 63-D-513 was prepared for analysis by H. A. Powers and a quantitative spectrographic analysis was run by $P$. R. Barnett, September 26, 1963, on spectrographic plate II DV-679. Glass from sample 513-3 was prepared for analysis by the writer and analyzed on April 14, 1964, by J. H. Haffty and Harriet Neiman on spectrographic plate II DV-704. The analyses of the two samples vary by smaller amounts than are considered significant in ashes from different volcanic eruptions. The results indicate that analyses of carefully prepared glass may be of uniform quality even though preparation and analysis is made by different persons at different times.

Description of the Volcanic Ash Beds

Outcrops of the two younger ash beds, a and $b$, are shown on the map (pl. 1) and their relative positions are shown in figure 6 . The third and oldest ash bed, herein referred to as bed $c$, crops out about 30 feet below bed $b$ in a south-facing highway cut in the Grizzly Ridge quadrangle, about 500 feet north of the Cerro Summit quadrangle in the NW $\frac{1}{4} E_{\frac{2}{4}}^{2}$ sec. 23, T. 49 N., R. 8 W. (fig. 8; field locality 513, samples 513-3, 63-D-513, table 5).

Bed $c, 0-4$ inches thick, occurs near the bottom of an arroyolike channel filled with bedded alluvium consisting of poorly sorted rounded to subrounded pebbles, cobbles, and boulders in a sandy, silty, 


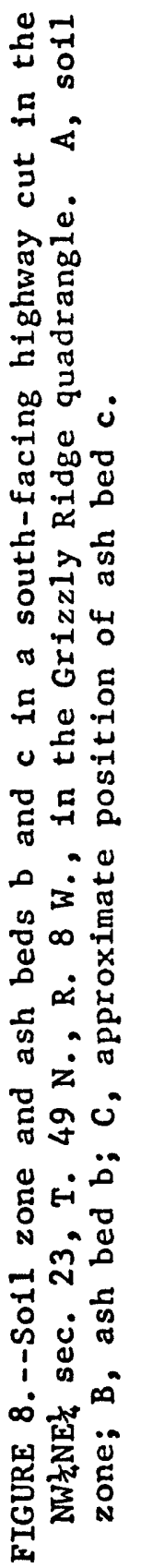




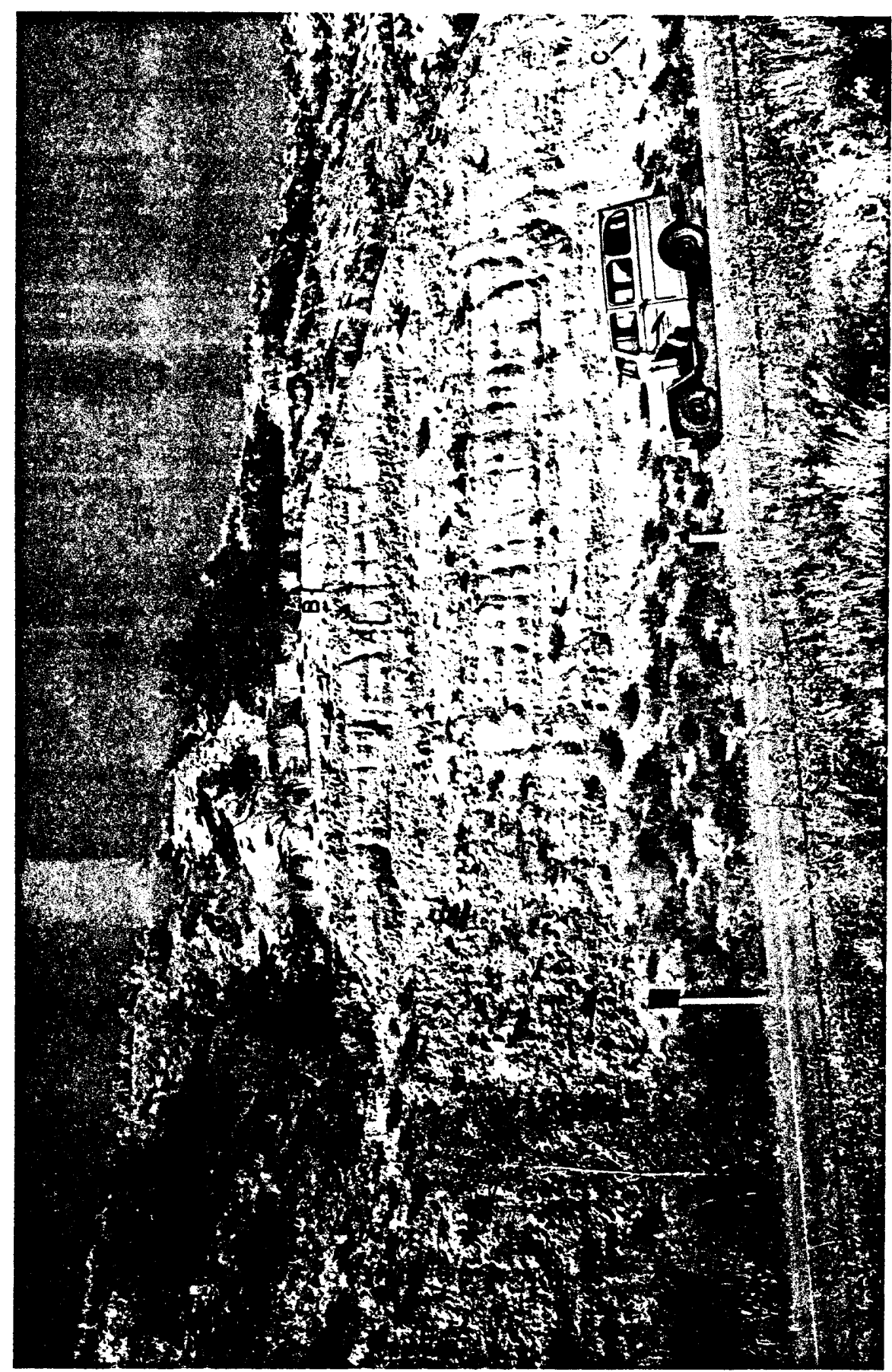


and clayey matrix. The shape of the channel is not well exposed, but drainage must have been northward into the Bostwick-Shinn Park valley. The sediments in the lower part of the channel appear to be equivalent to the basal gray gravel (unit I, fig. 7), but the contact between the two rock units is not exposed and the exact relationship is unknown. Ash $c$ is a white thinly banded bed of sandy volcanic ash that contrasts with the grayish orange of the enclosing alluvium. The ash is weakly cemented by calcium carbonate and includes scattered rounded balls or pellets of light-gray ash that are more sandy and clayey than the rest of the bed.

The ash of bed $c$ has a maximum shard size of about $0.5 \mathrm{~mm}$ and most of the fragments are of silt and clay size. The shards are mosty clear unaltered elongate pumiceous fragments consisting of closely packed tubular vesicles parallel to the length of the fragment. Many of the vesicles are closed tubes partly filled with gas. Most of the gas-filled tubes contain small amounts of liquid in the ends of the tubes. Some small rounded vesicles are also present. The shards are jagged fragments that show little evidence of rounding or wear. Ash $b$, the most extensive of the three ash beds, crops out at several localities in the valley-fill deposits (pl. 1). The ash bed ranges in thickness from 0 to about 2 feet and pinches out against the valley sides. The surface over which the ash was deposited, as indicated by the topographic position of the various outcrops of the ash, had a relief of over 80 feet, and locally the bed varies in elevation as much as 40 feet along the trace of a single outcrop. Ash b disconformably 
overlies sediments of variable composition, usually with a sharp contact. This ash overlies a caliche-cemented gravelly alluvium at

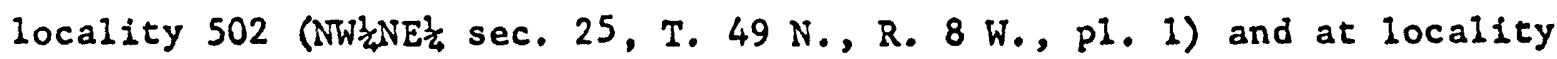
500 (SW $\frac{1}{4} \mathrm{SE}_{\frac{1}{4}}^{\frac{1}{4}}$ sec. 25, T. 49 N., R. 8 W., Pl. 1) the ash overlies finegrained silty sand. At localities 513 and 910 and at several other places in the valley-fill deposits, the ash overlies a moderately developed but partly stripped soil.

Ash $b$ has a gradational contact with overlying sediments. At locality 910 (pl. 1), 6 inches of white very clean ash (field No. 910-11; table 5) is overlain by a few inches of gravel, which in turn is overlain by about 2 feet (field No. 910-13, table 5) of volcanic ash that upward becomes progressively more sandy and silty. The lower ash (field No. 910-11) appears to be air-fall material. The upper ash (field No. 910-13), identical in its primary constituents to the ash of 910-11, is probably ash that has been locally reworked and redeposited. This sandy reworked material is typical of most exposures of the ash b at other localities.

The shards of ash $b$ are fragments comprised mostly of clear colorless glass, as much as $1 \mathrm{~mm}$ in diameter, that are parts of the curved walls of vesicles. Many of the fragments have riblike projections marking the broken junctures with other walls. Some fragments are elongate and consist of closely packed tubular vesicles. A few of the tubular vesicles are partly filled with liquid. Round vesicles occur in some fragments and many of these are gas filled, with small amounts of liquid adhering to the vesicle walls. 
Two small lentils of volcanic ash, which comprise the known extent of bed a, crop out about 160 feet above bed b in light-brown silty sand near locality 910 (fig. 7; Pl. 1) in the NE立SE- sec. 24, T. 49 N., R. 8 W. The lentils, 0-8 inches thick, consist of loose white ash that has a maximum shard size of about $0.30 \mathrm{~mm}$. The shards are mostly equant grains of chalky-appearing pumiceous glass formed of closely packed tubular- and oblate-shaped vesicles. Many of the closed vesicles contain small amounts of liquid. Ash a differs from $b$ and $c$ in shard size and shape-habit, refractive index of the glass, pheoncryst composition, and trace-element composition.

\section{Correlations of the Ash Beds}

The three volcanic ash beds in the Bostwick-Shinn Park valleyfill deposits have distinctive petrographic and chemical characteristics that can be compared with other ashes as a basis for correlation (table 5). Confident correlation of the ash beds with ash deposits elsewhere is handicapped by the scarcity of detailed information in the literature concerning the chemical and petrographic characteristics of other won ash deposits in the Western United States. The current status of the volcanic-ash chronology in the United States has been summarized by Wilcox (1965) and he indicates that considerable detailed study is needed.

The ash of bed a differs from $b$ and $c$ in shard size and shapehabit, refractive index of the glass, phenocryst composition, and traceelement composition. But, ash a does not appear to be mineralogically similar to any reported Pleistocene ash. $B$ and $c$, on the other hand, 
are mineralogically similar to the Pearlette Ash Member of the Sappa Formation in Nebraska and to the Pearlette-like ash reported on by Powers for the Saltaire core, Great Salt Lake, Utah (in Eardley and Gvosdetsky, 1960, p. 1331), and from the La Sal Mountains, Utah (In Richmond, 2962, P. 35).

$B$ and $C$ have seemingly identical chemical properties but they are dissimilar petrographically. Ash c differs from b in shard size, shape-habit, and in refractive index of the glass. The two ashes have the same heavy-mineral suite of phenocrysts, chevkinite, zircon, and clinopyroxene though phenocrysts in $c$ are smaller than those in $b$ and the value of the Beta index of the clinopyroxene is slightly lower in the two crystals available for measurement.

In accordance with the technique of Powers and Wilcox (1964), only those crystals with indigenous adherent glass were examined in the ashes at Bostwick-Shinn Park. The phenocryst content of ash beds in Bostwick-Shinn Park cannot be confidently compared with the phenocryst content reported for the Pearlette Ash Member and Pearlette-like ash beds because it is not clear if the phenocrysts reported in the ash by E. J. Young and Powers (1960) were only those with indigenous adherent glass or if some could have been detrital minerals. H. A. Powers generously loaned the writer a heavy-mineral fraction separated from the Pearlette Ash Member, type Sappa Formation, Harland County; Nebraska. Phenocrysts of chevkinite, clinopyroxene, and colorless zircon were noted. The other nonopaque heavy minerals including hornblende appeared to be devoid of adherent glass, and I would presume them to be detrital. 
This suggests that some of the phenocrysts reported in other samples by Young and Powers may have been detrital grains.

The Beta index of the clinopyroxene in ash $b$ is approximately 1.735, the same as that reported for the Pearlette and Pearlette-like ashes by E. J. Young and Powers (1960), whereas the Beta index of the clinopyroxene in ash $c$ appears to be approximately 1.723 , a value significantly lower than that of ash $b$ or the Pearlette-like ashes so far reported.

The major- and minor-element compositions of the Bostwick Park ashes are compared (table 5) with analyses of the Pearlette, Pearlettelike ashes, and other similar ashes reported by Powers (in Richmond, 1962, p. 35). The major oxide composition of ash b (field No. 910-11) is similar to that of the type Pearlette, the Pearlette-like ash of the La Sal Mountains, and the cited ash bed in the Saltaire core. The minor-element composition of ash b (Eield Nos. 910-11, 500-2, table 5) is indistinguishable from the type Pearlette and the western Pearlettelike ashes and also from the stratigraphically separate ash c. These facts indicate chemical composition, alone, cannot be used to differentiate some ashes.

Ash b appears to be identical in chemical composition, refractive index of the glass, shard shape-habit, and possibly in phenocryst composition with the type Pearlette Ash Member of Kansas; it is identical to the Pearlette-like ash of the La Sal Mountains and other Pearlettelike ashes in the western states. Thus, a tentative correlation of ash b with the type Pearlette and the Pearlette-like ashes seems reasonable, 
but, because of the similarity of ash $c$ to ash $b$ and the lack of clearly defined data concerning the phenocryst content of the Pearlette and the Pearlette-like ashes, definite correlation must await a more detailed study of the Pleistocene volcanic ashes of the Western United States.

\section{Correlation and Interpretation of the Valley-fill Deposits}

The following correlation and interpretation of the valley-fill deposits are based on the character of the sediments and soil profiles, some meager fossil evidence, tentative correlation of ash bed $b$, and geomorphic and stratigraphic relationships with the nearby Pleistocene pediment and terrace deposits in the Incompahgre River valley. The valley-fill deposits seem to be of middle and late Pleistocene age. The deposits are tentatively correlated with deposits of Cedar Ridge, Sacagawea Ridge, BuIl Lake, and Pinedale age in the Rocky Mountain region and with deposits of post-Nebraskan age in the mid-continent region. An accurate interpretation of the valley-fill deposits is difficult to make, however, because the soil profiles and volcanic ash beds which form prominent horizons in the deposits have not been precisely dated. Also, the deposits have not been traced laterally into glacial deposits and, therefore, cannot be directly related to the glaciations of the Pleistocene.

The lower terrace deposits in the Uncompahgre River valley can be traced into glacial deposits in the San Juan Mountains, and interpretation of the valley-fill deposits is best made in conjunction with an interpretation of the Pleistocene pediment and glacial terrace deposits in the Uncompahgre River valley. The writer's study of the 
pediment, terrace, and glacial deposits in the Uncompahgre River valley, however, has not been completed, and the present interpretation of the valley-fill deposits is tentative.

North of Ellison Gulch, the valley-fill deposits consist of a squenco of coarso and fine sediments separated by soil zones and disconformities. The sequence appears to reflect a cyclical pleistocene climate. Richmond (1962, p. 18) recognized in the La Sal Mountains of Utah generalized cyclical glacial-interglacial intervals that consist of four episodes. Starting with glaciation, Richmond recognized: widespread sedimentation in the valleys and glacial and colluvial erosion in the uplands; (2) eolian activity and arroyo cutting; (3) soil formation under conditions of essential slope stability; and (4) valley deepening and valley widening by stream erosion. The valleyfill deposits appear to reflect a similar cyclical pattern of deposition and soil formation but do not show evidence of major cyclic valley widening or deepening because the valley in which the sediments accumulated became a bssin of deposition after the stream, which had cut the valley and deposited the gravel of unit I (fig. 6), was captured by drainage in the Uncompahgre River valley. Erosion did occur, however, after each period of soil formation. The A horizon and a variable thickness of the B horizon are missing from all observed soil profiles In the valley-fill deposits. Locally, all the soil and an undetermined thickness of the underlying sediments were removed by erosion.

Sufficient control was not found in the valley-fill deposits to determine the climatic implication of the deposits. Most of the coarser 
conglomerates are discontinuous lenses, and they could represent deposition during a cool wet climate or during a warm dry climate when coarse debris was washed in by flash floods. In general, where coarse sediments predominate in a particular part of the valley-fill deposits, a cool climate has been inferred, and where fine sediments predominate, a warm climate has been inferred. More fossil evidence, however, may require adjustments in this interpretation.

The valley-fill deposits in the Ellison Gulch area have been divided into five stratigraphic units based primarily on lithology but in part on the writer's interpretation of the significance of the more strongly developed soil profiles. Units II, III, and IV (fig. 7) include both strong, or major, and weak, or minor, soils. Lacking a good tie to glacial deposits, the significance of the various profiles is not easily determined. Schultz and Tanner (1957, p. 73) noted that minor, if not major, fluctuations in climatic conditions may occur during glacial and interglacial times and that several soils may form during a single interglacial or interstadial period because unusually heavy floods and slope wash interrupted the formation of the soil. In the valley-fill deposits the thicker and better developed soils appear to represent major breaks during the Pleistocene and, accordingly, the deposits have been divided at these breaks. The interpretation of these soils as major breaks is supported by a similar sequence of major breaks in the Uncompahgre River valley that are represented by terrace and pediment gravels capped by seemingly comparable solls. 
The tentative age and correlation of the valley-fill deposits is shown in table 4 and figure 7. Unit $I$ and the lower part of unit II are believed to be of Cedar Ridge or Kansan age on the basis of the lithology of unit $I$, the occurrence of an equine molar of Pleistocene ago In unit I, oquino ramains of probabla poot-kanann ago in tho lowar beds of unit IIc, and a tentative correlation of ash b (unit IIb) with the late Kansan Pearlette Ash Member of the Great Plains area. The presence of local occurrences of coarse sediments in unit IIa suggests a continuation of the climate in which unit $I$ was deposited, and unit IIa is, therefore, considered to be of Cedar Ridge age. A minor soil occurs at the top of unit IIa, indicating that a period of slope stability occurred, probably during a period of ameliorated climate. The soil may mark a minor climatic fluctuation during Cedar Ridge time or the soil could indicate that the glaciers had retreated and could, therefore, mark the end of Cedar Ridge time. The overlying sediments of unit IIc are predominantly fine grained, which may indicate that they were deposited during interglacial time. The evidence is inconclusive, however, and an indefinite glacial-interglacial boundary is shown in figure 7. Most if not all of the sediments in unit IIc may be interglacial deposits of Cedar Ridge-Sacagawea Ridge age.

The thick strongly developed soil at the top of unit II is inferred to mark the boundary between the Cedar Ridge and Sacagawea Ridge Glaciations. The soil has the characteristics of pre-Bull lake soils in the Rocky Mountains (G. M. Richmond, oral commun., 1963) and forms a continuous marker horizon in deposits in the Ellison Gulch area. 


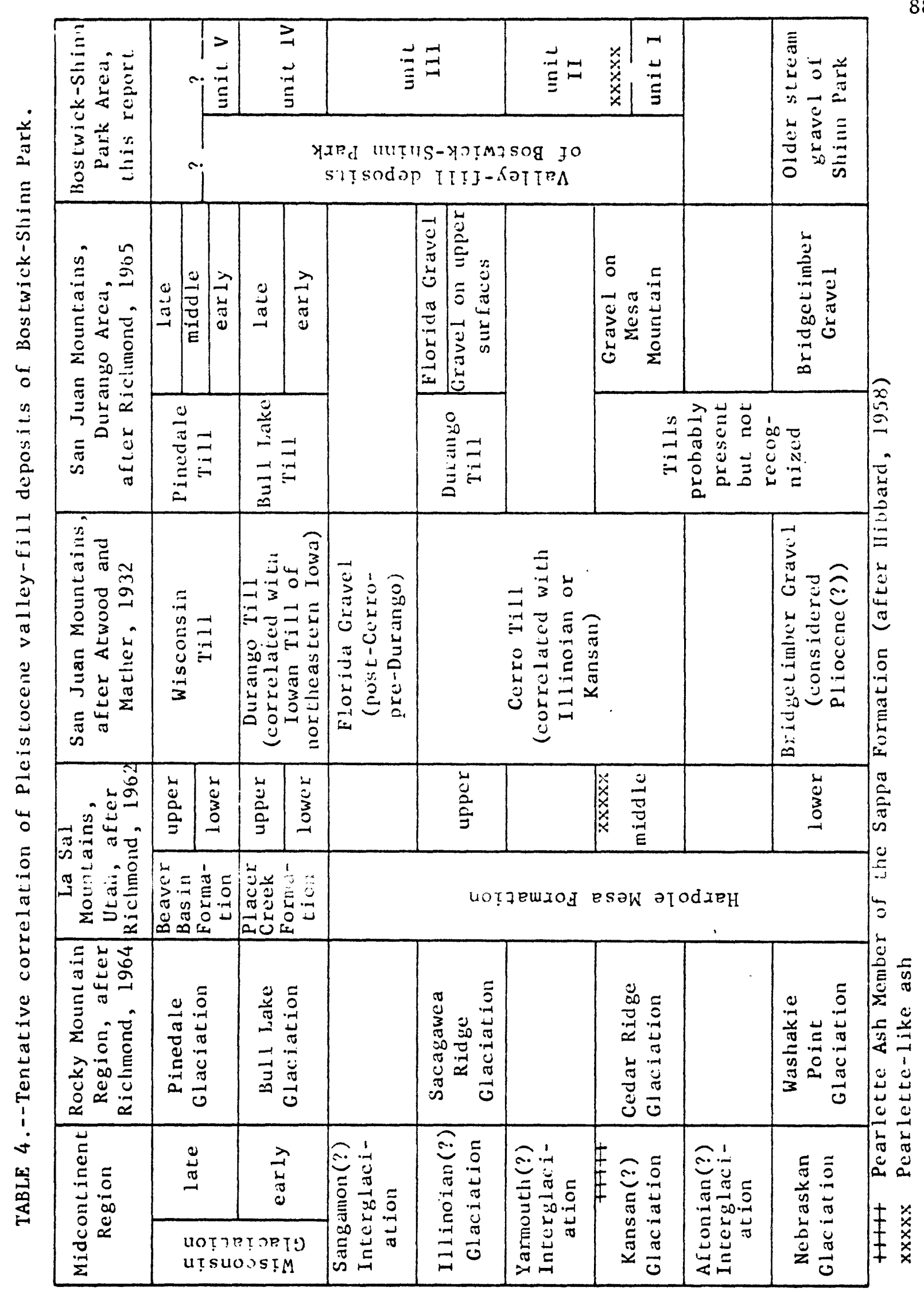


Unit III consists of sediments believed to be of Sacagawea Ridge and Sacagawea Ridge to Bull Lake age. This age assignment is based on the probable pre-Bull lake age of the soil profiles in the unit and the relationship of the sediments in the unit to the sediments above and below. No fossils were found in the unit and the volcanic ash, $a$, in unit IIIb is not as yet correlated with any other volcanic ash of known age.

Unit III has been divided into three parts that may represent major fluctuations of the Pleistocene climate. The top of unit IIIa Is placed at the top of a strongly developed pre-Bull Lake type of soil profile that is similar to the soil profile at the top of unit II. The soil at the top of unit IIIb is not as strongly developed as the soils at the top of units II and IIIa but it forms a mappable break in unit III. The top of unit IIIc is placed at a disconformity that is inferred to mark the boundary between sediments of the Sacagawea Ridge and Bull Lake ages.

The tentative interpretation that the three divisions of unit III represent major climatic fluctuations is supported in part by preliminary evidence that two or three major breaks occur in seemingly equivalent Pleistocene deposits in the adjacent Uncompahgre River valley. Preliminary evidence, based on correlation of deposits of volcanic ash $b$, indicates that two pediment gravels and two or three gravels that cap terrace remnants are equivalent in age to the sediments of unit III. The significance of the stratigraphic breaks in unit III and In seemingly equivalent deposits in the Uncompahgre River valley 
has not been determined. The seemingly equivalent unfossiliferous deposits in the Uncompahgre River valley have not been traced into glacial deposits of the San Juan Mountains. Until more evidence is found concerning the age of these deposits, they can only be tentatively corrolatod with tho Codar Rldgo Glaclation, and tho Cedar Rldgo-Bull Lake interglaciation. The sedimentary record in the Bostwick-Shinn Park and Uncompahgre River valley suggests that as many as three major fluctuations may have occurred during the period.

Unit IV includes sediments believed to be of Bull Lake or early Wisconsin age. Correlation is based primarily on the character of the soil profiles but is based also on the stratigraphic relationships of the sediments in the unit to the sediments above and below. The soil profiles appear to be comparable to those on Bull Lake deposits elsewhere in the Rocky Mountains (G. M. Richmond, oral commun., 1963) and on terrace deposits in the Uncompahgre River valley that can be traced Into moraines of probable Bull Lake age near Ridgway, Colorado. No . fossils were found in unit IV.

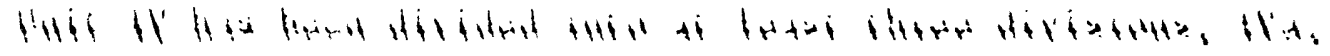
IVb, and IVc, that appear to represent climatic fluctuations of stadial proportions during Bull Lake time. Each division consists, in general, of coarse bouldery colluvium overlain by finer conglomeratic sand and silt. A strongly developed soil which may mark interstadial periods during Bull Lake time caps each of the divisions. Units IVa and IVb each have at least one soil of weaker proportion within the unit that 
was not traced or examined in detail. Further study is needed to determine significance of these soils.

Unit $V$ consists of eolian sand that overlies the eroded top of unit IV. No fossils were found in the unit and the age is uncertain. A tentative corralation with the Pinedale or late Wisconsin is ouggested by the position of the sediments over soils of Bull Lake type.

\section{PEDIMENT DEPOSITS}

Coarse poorly sorted bouldery debris veneers remnants of two pediment surfaces in the southwestern part of the Cerro Summit quadrangle. The remnants are part of former extensive pediments that flanked the east side of the Uncompahgre River valley during middle Pleistocene time. The Uncompahgre River has incised its valley several hundred feet below the level of the pediments and tributary drainages have dissected the pediments, leaving scattered isolated remnants.

\section{Upper Pediment Deposits}

Pediment deposits which cap the upper of two pediment surfaces in the Cerro Sumit quadrangle crop out in two small areas in sec. 21 , T. 49 N., R. 8 W. In addition, questionable pediment deposits were mapped in four small areas in sec. 10, T. 49 N., R. 8 W.

The deposits in the two small areas in sec. 21 are obscured by slope wash and can be described only from the bouldery debris exposed at the surface and on the hill slopes below. The deposits consist of poorly sorted fluvial and mudflow material, 0-50 feet thick, that unconformably overlies the Mancos Shale. The clasts are mostly 
volcanic rocks from the Cretaceous and Tertiary formations exposed along Cimarron Ridge. Some granitic and quartzitic boulders and cobbles from the Telluride Conglomerate are present along with some cobbles of calcareous sandstone of Late Cretaceous age. The material ranges in size from sand and clay to boulders as much as 3 feet in diameter. The upper 4 feet of the sediments is strongly cemented by caliche, which probably represents the $\mathrm{C}_{\mathrm{ca}}$ horizon of a strongly developed soil.

Though no fossils were found in the deposits, a Sacagawea Ridge or Illinoian age is indicated from their topographic and stratigraphic position. The deposits cap pediment remnants which occur high above outwash gravels of probable Bull Lake age in the Uncompahgre River valley. In sec. $10, T .49 \mathrm{~N} ., R_{0} 8 \mathrm{~W}$. , the pediment surface appears to be superposed on valley-fill deposits which include the gray gravel of unit I (Cedar Ridge age). A post-Cedar Ridge to pre-Bull Lake age is, therefore, indicated by the position of the pediment surface.

A Sacagawea Ridge age is also indicated by correlation of the deposits with pediment gravels that cap an apparently accordant high pediment north of Billy Creek, about 5 miles southwest of the Cerro Summit quadrangle. In this area, volcanic ash believed to be the same as ash $b$ in the valley-fill deposits of Bostwick-Shinn Park occurs in fine-grained sand and silt about 100 feet below the top of the pediment surface. The outcrop of volcanic ash was found the last day of the 1964 field season and the stratigraphic relationships may not have been accurately determined. Cursory examination indicates that the pediment 
gravel at the top of the exposed section is capped by a $\mathrm{C}_{\mathrm{ca}}$ horizon about 5 feet thick.

About 35 feet below the top of the pediment, a strongly developed soil crops out in probable landslide debris. The B horizon is about 2.5 foot thick and tho $C_{c a}$ horizon is 2-3 foet thick. Tho sold is of pre-Bull Lake character and may be equivalent to the strong soil at the top of unit II in the Ellison Gulch area. If so, the soil capping the pediment could be equivalent to the soil capping unit IIIa and the pediment gravel would be of Sacagawea Ridge age. The high pediment deposits in the Cerro Summit quadrangle may, therefore, be equivalent to unit IIIa and the Sacagawea Ridge age also.

\section{Lower Pediment Deposits}

Pediment deposits consisting of coarse poorly sorted alluvium, mudflow material, and colluvium crop out in a fan-shaped area along the southwest side of the quadrangle. The deposits, 0-50 feet thick, cap a pediment surface about 180 feet below remnants of the highest pediment along the east side of the Incompahgre River valley. The pediment has been dissected by Dry Cedar Creek and its tributaries and locally stripped of variable amounts of the upper part of the deposits.

The deposits themselves appear indistinguishable from those on the upper pediment. The clasts are predominantly volcanic rocks from the Cretaceous and Tertiary formations that crop out along Cimarron Ridge, but they include some quartzite and granitic material from the Telluride Conglomerate. Boulders as much as 3 feet in diameter are 
locally present. The upper 4-8 feet is strongly cemented with caliche that probably is a remnant $\mathrm{C}_{\mathrm{ca}}$ horizon.

The deposits appear to be of Sacagawea Ridge or Illinoian age. Again, fossils were not found in them but an approximate age can be Inferred from the strong $C_{c a}$ horizon at the top and from their geomorphic position with respect to the upper pediment deposits, the valley fill deposits of Bostwick-Shinn Park, and the terrace deposits in the Uncompahgre River valley. The pediment deposits are high above outwash terraces of probable Bull Lake age in the Uncompahgre River valley, indicating that they are of pre-Bull Lake age. The deposits occur topographically below the valley fill and the upper pediment deposits and, therefore, are younger. If the upper pediment deposits are of Sacagawea Ridge age as concluded on $p .93$, the lower pediment deposits must also be of Sacagawea Ridge age because they are pre-Bull Lake. The deposits may be equivalent to unit IIIb or IIIc (fig. 7) of the valley fill in the Ellison Gulch area. The pediment deposits along the Uncompahgre River valley have not been studied in sufficient detajl to determine if more than one pediment level exists below the upper pediment. Until further evidence of the age of the deposits 18 found, a tentative Sacagawea R1dge age is Inferred.

\section{EOLIAN DEPOSITS}

Eolian deposits crop out locally along the west side of Shinn Park, near the west border of the quadrangle. They consist of yellowishbrown fine sand, silt, and clay particles that have accumulated along the crest of the ridge between the Uncompahgre River valley and the 
valley at Shinn Park. The deposits, formed by wind deflation along the crest of the ridge, range from 0 to about 75 feet in thickness. No fossils were found in them. The deposits are similar to the eolian material in unit $V$ (fig. 6) of the valley-fill deposits in the Ellison Gulch area and are probably of late Pleistocene and Recent age.

\section{ALLUVIAL AND COLLUVIAL DEPOSITS}

Undifferentiated alluvium and colluvium was mapped along Pool Gulch, Cedar Creek, Dry Cedar Creek, and locally along the northeast side of Upper Bostwick Park. The deposits consist of fluvial gravels along the creek bottoms and colluvial debris along the valley sides. They are poorly exposed and were not studied in detail. The deposits appear to be of Pleistocene and Recent age, although no fossils were found in them. The alluvium and colluvium along Pool Gulch has probably been accumulating since the stream which cut the valley was captured in Pleistocene or earlier time. 


\section{STRUCTURE}

\section{Regional Setting}

The Cerro sumit quadrangle lies on the southwest flank of the Gunnison uplift near the boundary between the Colorado Plateau Province and the southern Rocky Mountains Province (Fenneman and Johnson, 1946). The major structural elements in the quadrangle, the Cimarron fault and the Montrose syncline, are related to Laramide ${ }^{2}$ crustal movements that formed the Gunnison and Uncompahgre uplifts. The Uncompahgre uplift, 3 which lies southwest of the Cerro Summit area, is a northwest-trending tilted block structurally similar to the Gunnison uplift. Mesozoic sedimentary rocks dip gently off the northeast flank of the Uncompahgre to the Montrose syncline where the dips reverse and the sedimentary rocks begin to arch over the core of the Gunnison uplift. The axis of the Montrose syncline parallels the southwest flank of the Gunnison uplift, passing through the Cerro Summit quadrangle from southeast to northwest.

1. Gilluly, J., 1963, excludes the Uncompahgre and Gunnison uplifts from the Colorado Plateau.

2. The term Laramide orogeny as used in this report includes late Mesozoic and early Tertiary deformation in the Rocky Mountains area.

3. In this report the Uncompahgre uplift is a Late Cretaceous and early Tertiary structure approximately concordant with the present Uncompahgre Plateau. The ancestral Uncompahgre highland is the late Paleozoic and early Mesozoic highland of southwestern Colorado and northern New Mexico. 


\section{Faults}

Faults in the Cerro Summit quadrangle resulted from both tectonic and nontectonic processes. The major faults and some associated minor faults are related to movements of the Gunnison uplift. The tectonic faults are difficult to map and study in the area because of the widespread surficial deposits. The actual extent of these faults may, therefore, be greater than that shown on the map (pl. 1). Gravityinduced surficial movements ranging from small landslides to detachment faults have occurred in the quadrangle, but only the detachment fault and some associated minor faults were mapped.

\section{TECTONIC FAULTS}

The Cimarron fault (Hunter, 1925, p. 88) is a high-angle fault that crosses the northeastern part of the Cerro Sumit quadrangle in a northwesterly direction. The fault is one of the major breaks in the region and can be traced for many miles east of the Cerro Summit area. Along much of the fault the Mancos Shale is exposed on the downfaulted southwest side in contact with Precambrian rocks on the northeast side. Differential exosion of the soft Mancos Shale has exposed a high faultline scarp which makes the fault easy to trace. The fault plane, however, is usually obscured by colluvium and the direction of dip is unknown in most places. Near the east border of the quadrangle, the trace of the fault is obscured by colluvium in Pool Gulch. The fault seems to follow the north side of the gulch for about a mile where it curves westward across the gulch and then back toward the northwest. 
West of Pool Gulch the fault is obscured by a thin colluvial cover but is easily traced because differential erosion has formed a marked topographic break.

Near the head of Upper Bostwick Park, the Cimarron fault splits into two segments: one segment veers northward, and a more western segment traverses the north side of Bostwick Park. The northern segment cuts only Precambrian rocks in the quadrangle, the overlying Mesozoic having been removed by erosion. This segment of the fault is marked by a fracture zone and a series of aligned saddles.

The western segment of the fault traverses the north side of Upper Bostwick Park but is obscured by colluvium and landslide debris and the fault plane was not observed. The trace of the fault is at best approximately located. Along this segment of the fault the Mancos Shale crops out on the downfaulted southwest side and the Morrison Formation crops out on the northeast side. The rocks northeast of the fault are badly broken by subsidiary faults.

The amount of throw on the Cimarron fault cannot be accurately measured because persisteni marker beds are not exposed along it. The throw varies considerably, becoming less west of where the fault splits. Hunter (1925, p. 90) estimated the throw on the Cimarron fault to be at least 2,500 feet and possibly as much as 3,500 feet in the Cerro Summit area.

In addition to the Cimarron fault, only two large faults, or fault zones, were recognized during field mapping in the Cerro Sumit quadrangle. One fault in the northwest corner of the quadrangle trends 
about N. $54^{\circ}$ W. The fault is recognizable because the bentoniticmarker bed in the Mancos Shale terminates northward against the fault and it is marked by a linear alignment of saddles and drainnges. The

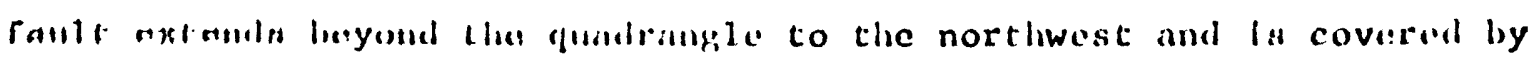
colluvium in Cedar Creek to the sollthoast. The amount or dirsction of vî̀set is uninom because the ientonitic-marker jed does not crop out northeast of the fault. If the fault is similar to the cimarron fault with the southwest side downdropped, the vertical offset is more than 200 feet.

The other fault, or fault zone, trends northeast across the south end of Coal Hill. The main part of the fault is concealed by landslide deposits but is marked by the abrupt northward termination of the silty-marker bed in the Mancos Shale. The offset in the beds across the fault zone is about 600 feet. A fault presumed to be subsidiary to the main one is partially exposed about 500 feet north on the west-facing slope of Coal Hill. This subsidiary fracture is interpreted to enclose a horse adjacent to the main fault that is downdropped about 400 feet.

The lateral extent of the fault or fault zone is unknown. The occurrence of Exiteloceras jenneyi (Whitfield) at USGS Mesozoic locality D4310, west of Coal Hill, indicates that the area of the fossil locality is structurally lower than the exposure of the silty-marker bed (zone of Didymoceras nebrascense) to the south. The fault may, therefore, extend beyond this area to the west. The fossils of locality D4310 were collected from landslide debris, and the writer was hesitant 
to extend a concealed fault on the basis of fossil evidence from landslide debris.

NONTECTONIC FAULTS

A concealed detachment fault was inferred in the southeastern part of the Cerro Summit quadrangle, north and east of Waterdog Peak. The fault encloses an area in which structurally discordant blocks, consisting of sandstone, shale, and coal beds of the Mancos Shale, the Pictured Cliffs Sandstone, and the Fruitland Formation, crop out. The blocks are discordant in relation to adjacent blocks and to the underlying Mancos Shale. The dip of the bedding in the blocks varies from a few degrees to as much as $25^{\circ}$. These dips contrast with the underlying relatively constant $2^{\circ} \mathrm{NE}$. dip of the silty-marker bed, which underlies the area in which the detachment blocks occur. The thickness of Mancos Shale between the silty-marker bed and the Pictured Cliffs is variable, generally becoming less to the north and west of the southwest corner of the quadrangle. It is difficult to determine how the blocks moved into their present positions because most of the area is obscured by relatively thin landslide debris. The disordered array of blocks seems best explained by detachment faulting, or megalandsliding. A hypothetical detachment fault, the character of which is perhaps more diagrammatic than real, is, therefore, shown on the map. The mapped trace of the detachment fault was arbitrarily placed in the Mancos Shale between the silty-marker bed and the upper part of the detached blocks on the assumption that the glide plane was within beds of the Mancos. 
Small faults between blocks in the upper plate of the fault are indicated by offset bedding, variation in dip between the blocks, and usually by a topographic break. Thick vegetation and the ever-present landslide debris obscure most of the faults and it is impossible to trace tham lataraliy for any distance. It it also impossible to determine how the faults are related to the hypothetical detachment fault. The detachment fault may have had more than one stage of movement, as suggested by a crude grouping of the blocks, the general attitudes of the blocks in one group being different from the attitude of those in the adjacent group. The three lobe-shaped areas (pl. 1) enclosed by the detachment fault represent groups of blocks that may have moved as units, perhaps at different times. The detachment faulting probably occurred during early late Tertiary or early Pleistocene time.

\section{Folds}

The Montrose syncline, on the southwest flank of the Gunnison uplift, trends about N. $45^{\circ} \mathrm{W}$. across the central part of the quadrangle. The syncline is a broad asymmetrical structure that extends for many miles northwest of the quadrangle (W. R. Hansen, oral commun., 1964). The syncline is well defined by outcrops of the bentonitic-marker bed in the Mancos Shale in the northeastern part of the quadrangle and by the silty-marker bed in the Mancos Shale in the southeastern part, but becomes obscured by landslide debris about a mile to the southeast. In the quadrangle, the beds of the southwest flank of the syncline dip about 
$2^{\circ} \mathrm{NE}$. The northeast flank of the syncline becomes steeper as the core of the Gunnison uplift is approached. Dips as much as $27^{\circ}$ were measured south of the Cimarron fault, and along the River Portal Tunnel Road north of the Cimarron fault dips between $50^{\circ}$ and $60^{\circ}$ were measured. The syncline is well defined in the southeastern part of the quadrangle by outcrops of the silty-marker bed and in the northeastern part by outcrops of the bentonitic-marker bed. The axis of the syncline was projected between the two areas through an area almost completely covered by landslide debris.

The Precambrian rocks of the northeastern part of the quadrangle contain folds of undetermined extent but they are not well exposed and were not mapped in detail. A plunging overturned anticline and an adjacent syncline crop out on Poverty Mesa east of Pool Guich. These structures may be minor folds on the crest of a larger anticline (W. R. Hansen, oral commun., 1964).

\section{Age of Deformation}

The geologic history of the Cerro Summit area includes three major episodes of tectonic activity which, in general, represent the closing of the Precambrian, the Paleozoic, and the Mesozoic. The two earlier episodes of tectonic activity cannot be readily studied in the quadrangle because of Iimited exposures of older rocks, but the episodes are known from rocks in adjacent areas (Hansen, 1965, p. 44). By Early Cambrian time the Precambrian rocks had been metamorphosed, intruded, faulted, uplifted, and eroded. Tectonic activity occurred again during 
late Paleozoic time, and by early Mesozoic time erosion had beveled the area, removing an undetermined thickness of Paleozoic and Mesozoic rocks.

The third episode of tectonic activity, the Laramide orogeny, occurred from Late Cretaceous to middle Tertiary. The Gunnison and Uncompahgre uplifts, to which most of the structure in the quadrangle is related, formed during this period of deformation. The youngest preserved formation involved in the uplift is the Upper Cretaceous Fruitland Formation (late Campanian to early? Maestrichtian) which is exposed near the axis of the Montrose syncline. By middle Tertiary time erosion had removed an undetermined thickness of Upper Cretaceous and lower Tertiary rocks that possibly were involved in the uplift. Inferences from rocks exposed in adjacent areas suggest that the Gunnison uplift formed during Late Cretaceous time, although no proof exists that some uplift did not occur at a later time also. Northwest of the Gunnison uplift, the Upper Cretaceous Mesaverde Formation (the lower part of which is equivalent to the Fruitland Formation of the Cerro Summit area) thins toward the Gunnison uplift from the center of the Piceance Creek Basin (J. R. Donnell, oral commun., 1965). The thinning could be a depositional or erosional feature, or both, but a high is suggested in the area of the Gunnison uplift during the Late Cretaceous.

A Late Cretaceous (Maestrichtian?) age of deformation for the Gunnison and Uncompahgre uplifts may be inferred from structural and stratigraphic relationships in the Cimarron Ridge area on the north flank of the San Juan Mountains. Considerable uplift and erosion in Late Cretaceous (Maestrichtian?) time is indicated by the stratigraphic 
and structural relationships of Maestrichtian rocks of the Cimarron Ridge area as is shown in figure 2, a diagrammatic section drawn parallel to the ridge. The deformation is best expressed in the area between Lou Creek and Nate Creek where volcanic rocks of Late Cretaceous age unconformably overlie Mancos Shale and Fruitland Formation. The area is mostly covered by landslide debris and the exact nature of the Maestrichtian structure is not known. The middle to lower part of the Mancos Shale seems to be in fault contact with coal-bearing beds of the Fruitland Formation. These rocks are overlain by discontinuous outcrops of unnamed Upper Cretaceous volcanic conglomerate, tuff breccia, and flow breccia which rest on a surface of low relief. In the Nate Creek area, several thousand feet of Mancos Shale, Fruitland Formation, and Kirtland Shale are missing beneath the unconformity. Further evidence of this Late Cretaceous deformation occurs in the Cow Creek area about 4 miles south of Nate Creek where granodiorite porphyry of probable Late Cretaceous age intrudes an older monoclinal(?) structure of Late Cretaceous age.

The tectonic activity recorded in the Lou Creek area seems to be connected with faulting on the southeast end of the Uncompahgre uplift by the Ridgway fault (fig. 1). This fault extends east-west along the north side of Dallas Creek, north of Ridgway, Colorado, and projects esstward into the Lou Creek area (Cross, Howe, and Irving, 1907). If the Ridgway fault and the fault in the Lou Creek area sre the same structure, the southeastern part of the Uncompahgre uplift probably formed during Late Cretaceous time. From the evidence in the 
Lou Creek area no movement occurred on the fault after deposition of the unnamed Late Cretaceous volcanics, and the tectonic activity appears restricted to the Late Cretaceous.

A direct link between the Uncompahgre uplift and the Gunnison uplift is not known. The two uplifts are similar in many respects and appear to have formed by compressive forces of similar orientation, possibly during the same period of deformation. Both structures are also structural highs that have summits of nearly accordant elevation. Thousands of feet of sediments have been removed from the crest of each uplift, but there are no known deposits of the eroded material nearby. The rocks north and west of the Gunnison and Uncompahgre uplifts indicate that the area was high in tate cretaceous time and as late as Eocene time. The above evidence suggests that the Gunnison and Uncompahgre uplifts were contemporary, and the evidence in the Lou Creek area suggests that they are of Late Cretaceous age.

No middle to late Cenozoic tectonic activity was recognized in the Cerro Summit quadrangle. Hansen (1965, p. 67) has mapped a gentle post-Potosi synclinal structure along the Gunnison River that may have affected the dip of rocks in the Cerro Sumit area. The syncline is superposed on the Gunnison uplift. Gentle tilting, to the southeast, in middle Tertiary time is suggested by the dip of the Telluride Conglomerate along Cimarron Ridge, but Telluride is not present in the Cerro Summit area and no evidence of the tilting could be found in the poorly exposed rocks. 
The major geologic events are the emplacement and metamorphism of the Precambrian rocks, uplift during late Paleozoic or early Mesozoic time, deposition of the Upper Jurassic to Upper Cretaceous rocks, uplift during Laramide time, deposition of Upper Cretaceous and middle Tertiary volcanic rocks, and erosion and deposition during late Tertiary and Quaternary time. The geologic history and geomorphic development of the Cerro Summit area are based partly on evidence from other areas, especially the Cimarron Ridge area and the Uncompahgre River valley.

\section{Precambrian Era}

In Precambrian time, sedimentary rocks were metamorphosed, complexly folded, faulted, and injected by granitic and gabbroic material. Uplift and erosion are believed to have occurred before Paleozoic time, and an unknown thickness of rocks was removed as the area was reduced to one of low relief.

\section{Paleozoic Era}

The Paleozoic is not represented in the rocks of the quadrangle, and events during this era must be inferred from rocks in adjacent areas. Marine deposition probably occurred over the area in early Paleozoic time. By Early Pennsylvanian time, however, the ancestral 
Uncompahgre highland had been uplifted and the Cerro Sumit area probably remained high until middle Mesozoic time.

Mesozoic Era

In Triassic time the-ancestral Uncompahgre highland was eroded to a low plain. Subsidence began and sediments encroached on the flanks of the former highland. Possibly, rocks of Triassic age were deposited in the southwestern part of the Cerro Sumit quadrangle. The area was nearly covered by the onlap of the nearshore and dune sands of the Upper Jurassic Entrada Sandstone and was entirely covered by the shallow sea in which the few feet of limestone, at the base of the Wanakah Formation, was deposited. A continental environment persisted through the rest of the Jurassic and the Early Cretaceous. The sandstone, siltstone, gypsum, and mudstone of the Wanakah and Morrison Formations accumulated in fresh-water lakes and swamps and on low-lying flood plains in Jurassic time; the channel sandstone and conglomerates of the Burro Canyon Formation were deposited by streams during Early Cretaceous time. Submergence began again the early Late Cretaceous with Dakoca Sandstone being deposited as the sea advanced southward across the area. The area remained submerged during most of the Upper Cretaceous and several thousand feet of shale accumulated. The sea withdrew from the area during middle Campanian time, presumably as the area began to rise epeirogenically. As the sea withdrew, the Pictured Cliffs Sandstone was deposited. Subsequently, the brackish- and fresh-water sands, shales, and coal beds of the Fruitland Formation were deposited over 
the Pictured Cliffs. Accumulation of nonmarine sand and shale continued until early(?) Maestrichtian time when uplift (Laramide) of mountainous proportions began to affect the region.

Evidence in the adjoining Cimarron Ridge area suggests that extensive uplift and erosion occurred near the end of Late Cretaceous time. Before the end of that epoch, however, volcanism began in the San Juan area and volcanic debris spread at least as far north as the Cerro Summit area.

\section{Cenozoic Era}

Cenozoic time is represented in the Cerro summit quadrangle by some conglomerate and tuff breccia of middle Tertiary age on Poverty Mesa and by alluvium, colluvium, and mass-wasting debris of late Tertiary and Quaternary age over much of the rest of the area!. Most of the Tertiary history must be inferred from nearby areas. During early Tertiary time, sediments accumulated in the Piceance Creek Basin to the north. and the San Juan Basin to the south. In the San Juan area, volcanism that started in Late Cretaceous time may have continued into the Paleocene. Rocks of early Tertiary age are not preserved, however, in the Cerro Summit and Black Canyon areas. Any sediments which did accumulate were removed by erosion before middle Tertiary time. Possibly, the area was high because of continued Laramide uplift but the evidence is inconclusive.

By middle Tertiary time the Cerro Sumit area was a low flood plain over which a thin deposit of gravels had accumulated. Volcanism 
began in the areas of the present San Juan and West Elk Mountains and detritus from these volcanic centers spread into the area. The ancestral Gunnison River probably began to establish its course during this time. The river mixed detritus from the growing volcanic piles with granitic rocks from its source in the Sawatch area and deposited gravels like those on Poverty Mesa. The middle Tertiary volcanism ended with widespread eruptions of ash which formed the welded tuff of the Potosi Volcanic Group.

Following these eruptions, gentle warping formed a broad shallow syncline in the area of the present Black Canyon. The Gunnison River established its course along the axis of the syncline and by the end of Pleistocene time had cut a canyon about 2,000 feet deep, exposing the core of the Gunnison uplift.

During late Tertlary and early Pleistocene time, the Cerro Summit area consisted of hills and valleys through which two large streams flowed. A large stream, possibly the ancestral Cow Creek, traversed the west side of the quadrangle in the Bostwick-Shinn Park area, and a stream, possibly the ancestral Cimarron Creek, crossed the nottheastern part of the area through Pool Gulch. West and south of the quadrangle, a divide, possibly in the form of a group of low hills, separated the Bostwick-Shinn Park valley from the Uncompahgre River valley. The eastern part of the quadrangle was probably a hilly area that sloped upward to the east and formed the divide between the ancestral Cimarron Creek and the stream that flowed through Bostwick-Shinn Park. This drainage pattern was established some time in the Tertiary, 
probably not long after the welded tuffs of the Potosi Volcanic Group were erupted. By Cedar Ridge time, in the Pleistocene, the stream flowing through the Bostwick-Shinn Park valley on its way to the Gunnison River had cut a canyon (Red Rocks Canyon) about 1,000 to 1,700 feet deep in the relatively hard Precambrian core of the Gunnison uplift. Pool Gulch, which is about 1,000 feet deep, had been cut by the ancestral Cimarron Creek, but it is not known when the ancestral Cimarron Creek was diverted to its present course to the Gunnison River. Some time late in Cedar Ridge time or possibly early Cedar Ridge to Sacagawea Ridge time, the ancestral Cow Creek(?) was diverted to the west into the Uncompahgre River, leaving its former valley relatively dry but with a thick deposit of coarse stream gravel in the bottom of the valley. Deposition continued to fill the valley until abóut Pinedale time when the headwardly eroding Cedar Creek cut across the valley and captured most of the drainage which had been depositing sediment in the valley.

Several Pleistocene events are recorded in the valley-fill deposits of Bostwick-Shinn Pari. Three volcanic eruptions, most likely in the western part of the United States, are recorded as ash beds in the valley-fill deposits, two in Cedar Ridge time and the third during Sacagawea Ridge time. The younger ash (b) of Cedar Ridge age is Pearlette-like in composition and may be correlative with the widespread Pearlette Ash Member of the Great Plains region. The stronger soils in the valley-fill deposits appear to mark climatic fluctuations of interstadial and interglacial proportions. 
The Uncompahgre River cut down rapidly during middle' to late Pleistocene time and the Uncompahgre valley was markedly changed. After the stream which cut the Bostwick-Shinn Park valley was diverted to the Uncompahgre, pediments formed along the east side of the Uncompahgre valley and the divide,between the Bostwick-Shinn Park and the Uncompahgre valleys was destroyed. At least two pediments, which appear to have formed during Sacagawea Ridge time, extended into the Cerro summit area. Subsequent erosion and downcutting dissected the pediments, leaving only remnants of the former extensive surface.

Since late Tertiary time, the dominant landform in the Cerro Summit quadrangle has probably been a hummocky terrain marked by numerous landslide scarps. The gravity-induced surficial movements which formed this terrain ranged in magnitude from surficial creep to detachment faults.

During Recent time, colluvial and alluvial deposition has occurred along the stream valleys and minor landsliding continues in several small areas. 
ECONOMIC GEOLOGY

Geologic materials of known or potential value in the quadrangle include coal, oil and gas, clay, and sand and gravel.

\section{Coal}

Subbituminous coal occurs in the Fruitland Formation at several localities in the southeastern part of the quadrangle. Several small test pits and prospects occur in the area, but the only coal produced has been for local use. The largest known area in which coal occurs is at the top of Coal Hill where about 3 feet of weathered bony coal crops out around the top of the hill. Coal crops out locally in the detached blocks along the ridge east of Waterdog Peak. The coal probably consists of one 3- to 5-foot bed and one or more thinner beds. This coal is at the same horizon as the coal in Coal Hill. The quantity of coal in the beds appears to be small and locally has been burned. Analyses of fresh coal from outcrops in the quadrangle are not avail.. able.

Some discontinuous thin beds of bony coal may occur in the subsurface Dakota Sandstone of the quadrangle, as inferred from the outcrops of coal in the Dakota in adjacent areas. The Dakota Sandstone probably occurs at depths greater than 1,000 feet in most of the area, and any contained coal would probably be of little value under present economic conditions. 
Oil and Gas

An estimated 4,000 to 6,000 feet of sedimentary rocks occur in the quadrangle. Reservoir rocks are present in the Entrada, Wanakah, Morrison, and Dakota Formations, but the rocks have not been tested for oil or gas. A well in sec. 15, T. 48 N., R. 8 W.; about a mile north of the northwest corner of the quadrangle was dry. Minor amounts of gas have been reported from the Mancos Shale in the Ridgway field approximately 12 miles south of the quadrangle and from the Morrison Formation in the Black Canyon approximately 20 miles northwest of the township (Kuhn, 1958).

Clay

Clay occurs in the Wanakah, Morrison, Dakota, Mancos, and Fruitland Formations. No clay has been mined from the rocks of the area and the potential value of the clay is unknown.

\section{Sand and Gravel}

Sand and gravel of widely variable quality is available in the quadrangle. Potential sources of sand and gravel occur in all the mapped Tertiary and Quaternary units with the possible exception of the landslide deposits. Gravel has been quarried from several localities in the basal gravel (unit I, fig. 6) of the valley-fill deposits of Bostwick-Shinn Park for road metal, but the other sources remain untested. 


\section{REFERENCES CITED}

Atwood, W. W., 1915, Eocene glacial deposits in southwestern Colorado: U.S. Geol. Survey Prof. Paper 95-B, P. 13-26.

Atwood, W. W., and Mather, K. F., 1932, Physiography and Quaternary geology of the San Juan Mountains, Colorado: U.S. Geol. Survey Prof. Paper 166, 176 p.

Baltz, E. H., Jr., 1955, A reconnaissance for uranium in carbonaceous rocks in southwestern Colorado and parts of New Mexico: U.S. Geol. Survey TEM-915, 52 P., issued by U.S. Atomic Energy Comm. Tech. Inf. Service, Oak Ridge, Tenn.

Burbank, W. S., 1930, Revision of geologic structure and stratigraphy in the Ouray district of Colorado, and its bearing on ore deposition: Colorado Sci. Soc. Proc., v. 12, no. 6, p. 151-232.

Craig, L., Holmes, C. N., Freeman, V. L., Muliens, T. E., and others, 1959, Measured sections of the Morrison Formation and adjacent beds in the Colorado Plateau Region, Colorado, New Mexico, and Utah: U.S. Geol. Survey open-file report.

Cross, C. W., and Spencer, A. C., 1899, Description of the La Plata quadrangle, Colorado: U.S. Geol. Survey Geol. Atlas, Folio 60, 14 p.

Cross, C. W., Howe, Ernest, and Irving, J. D., 1907, Description of the Ouray quadrangle [Colorado]: U.S. Geol. Survey Geol. Atlas, Folio 153, 20 p.

Cross, C. W., and Larsen, E. S., 1935, A brief review of the geology of the San Juan region of southwestern Colorado: U.S. Geol. Survey Bull. 843, 138 p.

Dickinson, R. G., 1965, Landslide origin of the type Cerro Till, southwestern Colorado: U.S. Geol. Survey Prof. Paper 525-C, P. C147C151.

Eardley, A. J., and Gvosdetsky, Vasyl, 1960, Analysis of Pleistocene core from Great Salt Lake, Utah: Geol. Soc. America Bull., v. 71 , no. 9, P. 1323-1344.

Eckel, E. B., and others, 1949, Geology and ore deposits of the La Plata district, Colorado: U.S. Geol. Survey Prof. Paper 219, 179 p. 
Eldridge, G. H., 1894, Descriptions of the sedimentary formations, in Emmons, S. F., Cross, Whitman, and Eldridge, G. H., AnthraciteCrested Butte [Colorado]: U.S. Geol. Survey Geol. Atlas, Folio 9 , p. 6-10.

Erdmann, C. E., 1934, The Book Cliffs coal field in Garfield and Mesa Counties, Colorado: U.S. Geol. Survey Bull. 851, 150 p.

Fenneman, N. M., and Gale, II. S., 1906, The Yampa coal field, Routt County, Colorado: U.S. Geol. Survey Bull. 297, 96 p.

Fenneman, N. M., and Johnson, D. W., 1946, Physical divisions of the United States: U.S. Geol. Survey map.

Fisher, D. J., 1936, The Book Cliffs coal field in Emery and Grand Counties, Utah: U.S. Geol. Survey Bull. 852, 104 p.

Flint, R. F., 1947, Glacial geology and the Pleistocene epoch: New York, John Wiley and Sons, $589 \mathrm{p}$.

Gale, H. S., 1909, Coal fields of northwestern Colorado and northeastern Utah: U.S. Geol. Survey Bli11. 341-C, p. 283-315.

Gilluly, James, 1963, The tectonic evolution of the western United States: Geol. Soc. London Quart. Jour., no. 474, v. 119, pt. 2, p. 133-174.

Hansen, W. R., 1964, Curecanti pluton, an unusual intrusive body in the Black Canyon of the Gunnison, Colorado: U.S. Geol. Survey Bul1. 1181-D, 15 P.

1965, The Black Canyon of the Gunnison, today and yesterday: U.S. Geol. Survey Bull. 1191, 76 p.

Hibbard, C. W., 1958, New stratigraphic names for Eaxly Pleistocene deposits in southwestern Kansas: Am. Jour. Sci., v. 256, no. 1, p. 54-59.

Hil18, R. C., 1884, Extinct glaciers of the San Juan Mountains, Colorado: Colorado Sci. Soc. Proc., v. 1, p. 39-46.

Holmes, W. H., 1877, Report [on the San Juan district, Colorado] : U.S. Geol. and Geog. Survey Terr., 9th Ann. Rept. for 1875, p. 237276.

Howe, Ernest, 1909, Landslides in the San Juan Mountains, Colorado: U.S. Geol. Survey Prof. Paper 67, 58 p.

Hunter, J. F., 1925, Pre-Cambrian rocks of Gunnison River, Colorado: U.S. Geol. Survey Bul1. 777, 94 p. 
Kuhn, P. J., compiler and editor, 1958, 0il and gas in the Four Corners: Amarillo, Texas, National Petroleum Bibliography, 298 p.

Kulp, J. I., 1961, Geologic time scale: Science, v. 133, no. 3459 , p. 1105-1114.

Lee, W. T., 1909, The Grand Mesa coal field, Colorado: U.S. Geol. Survey Bul1. 341-C, p. 316-334.

Lee, W. T., and Knowlton, F. H., 1917, Geology and paleontology of the Raton Mesa and other regions in Colorado and New Mexico: U.S. Geol. Survey Prof. Paper 101, 450 p.

Llang, Ta, 1952, Landslides, an aerial photographic study [Cornell University doctoral thesis]: Ann Arbor, Michigan, University Microfilms, Inc.

Luedke, R. G., and Burbank, W. S., 1964, Tertiary volcanic stratigraphy in the western San Juan Mountains, Colorado: Art. 70 in U.S. Geol. Survey Prof. Paper 475-C, p. C39-C44.

Pettijohn, F. J., 1963, Chemical composition of sandstones--excluding carbonate and volcanic sands, in Data of geochemistry, 6th ed.: U.S. Geol. Survey Prof. Paper $\overline{440-S, ~ p . ~ S 1-S 21 . ~}$

Powers, H. A.', and Wilcox, R. E., 1964, Volcanic ash from Mount Mazama (Crater Lake) and from Glacier Peak: Science, v. 144, no. 3624, p. 1334-1336.

Richardson, G. B., 1907, The Book Cliffs coal field between Grand River, Colorado, and Sunnyside, Utah: U.S. Geol. Survey Bull. 316-E, P. 302-320.

Richmond, G. M., 1962, Quaternary stratigraphy of the La Sal Mountains, Utah: U.S. Geol. Survey Prof. Paper 324, 135 p.

1964, Three pre-Bull Lake tills in the Wind River Mountains, Wyoming--a reinterpretation: U.S. Geol. Survey Prof. Paper 501-D, P. D104-D109.

1965, Quaternary stratigraphy of the Durango area, San Juan Mountains, Colorado: U.S. Geol. Survey Prof. Paper 525-C, P. C137C143.

Schultz, C. B., and Tanner, I. G., 1957, Medial Pleistocene fossil vertebrate localities in Nebraska: Nebraska State Mus. Bull., v. 4 , no. 4 , p. 59-81. 
Simmons, G. C., 1957, Contact of Burro Canyon formation with Dakota sandstone, Slick Rock district, Colorado, and correlation of Burro Canyon formation: Am. Assoc. Petroleum Geologists Bull., v. 41 , no. 11 , P. 2519-2529.

Spieker, E. M., 1949, Sedimentary facies and associated diastrophism in the Upper Cretaceous of central and eastern Utah, in

Longwell, C. R., chm., Sedimentary facies in geologic history symposium : Geol. Soc. America Mem. 39, p. 55-81.

Spieker, E. M., and Reeside, J. B., Jr., 1925, Cretaceous and Tertiary formations of the Wasatch Plateau, Utah: Geol. Soc. America Bull., v. 36 , no. 3, p. 435-454.

Varnes, H. D., 1949, Landslide problems of southwestern Colorado: U.S. Geol. Survey Circ. 31 , $13 \mathrm{p}$.

Weimer, R. J., 1960, Upper Cretaceous stratigraphy, Rocky Mountain area: Am. Assoc. Petroleum Geologists Bul1., v. 44, no. 1, p. $1-20$.

Wilcox, R. E., 1959, Use of the spindle stage for determination of principal indices of refraction of crystal fragments: Am. Mineralogist, v. 44, nos. 11-12, p. 1272-1293.

1962, Cherkasov's "focal screening" for determination of refractive index by the immersion method, in McCrone, W. C., ed., Proceedings of the International Microscopy Symposium, Chicago, 1960 [1962]: Chicago, Illinois, McCrone Associates, p. 160-165.

1965, Volcanic-ash chronology, in The Quaternary of the United States: Princeton, New Jersey, University Press, p. 807-816.

Young, E. J., and Powers, H. A., 1960, Chevkinite in volcanic ash: Ari. Mincralogist, v. 45 , nos. 7-8, p. 875-881.

Young, R. G., 1960, Dakota Group of Colorado Plateau: Am. Assoc. Petroleum Geologists Bul1., v. 44, no. 2, p. 156-194.

Zapp, A. D., and Cobban, W. A., 1960, Some Late Cretaceous strand lines in northwestern Colorado and northeastern Utah: Art. 112 in U.S. Geol. Survey Prof. Paper 400-B, P. B246-B249. 


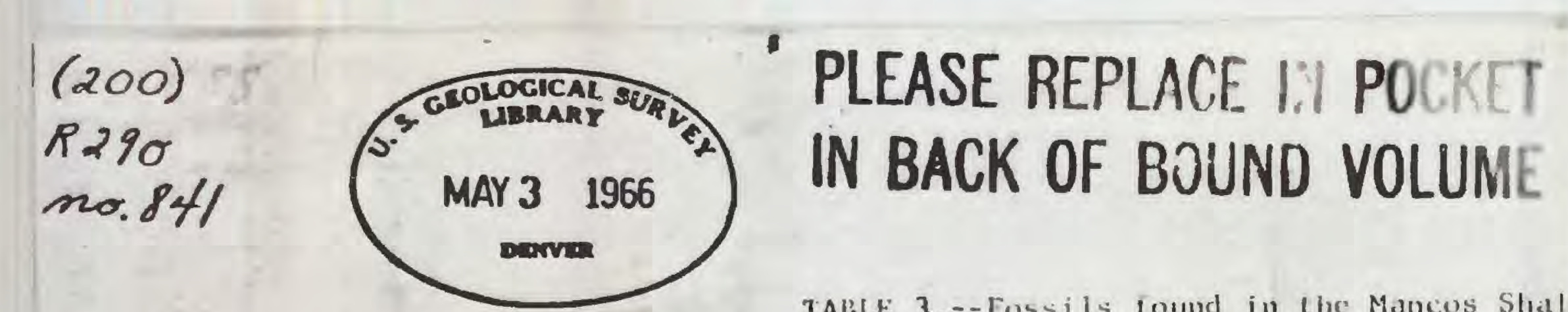

USGS Mesnzode locallty

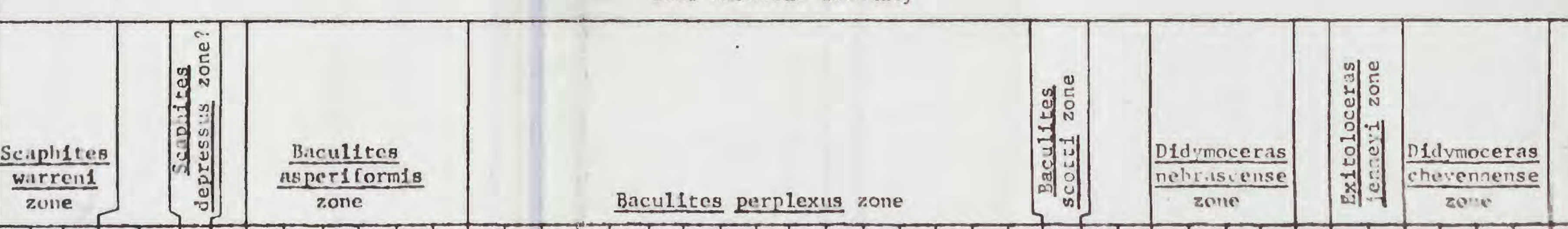

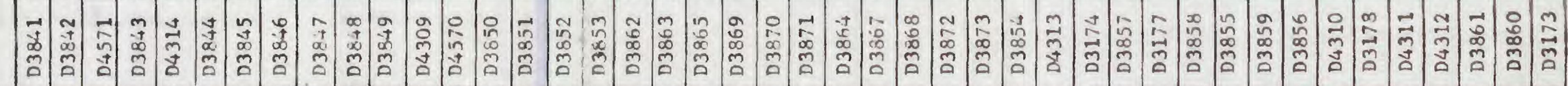

BRYOZONN

\section{Bryozoan (pyriportil}

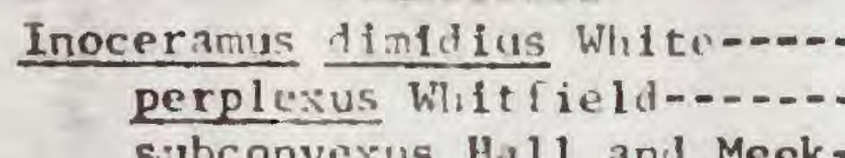

subconvexus Ha11 and Merk-.

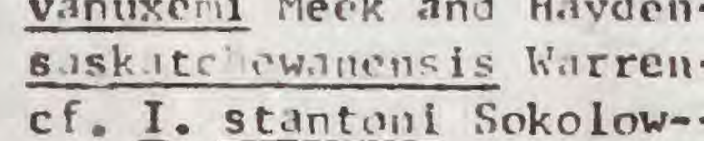

cf. $\frac{\underline{I}}{\underline{r}} \cdot \frac{\text { halticus }}{\text { vanuxemi }}$ Boech and

cf. $\underline{I}_{1}$. typicus (Whitfield)

cf. $\underline{\underline{i}}$. proximus Tuomey-...

Ostre: luguirt congest. Conrad

mesenterica Morto.........

cf. $\underline{0}$. Inornata Meek and

$\frac{\text { Pteria }}{\mathrm{sp} \text {. }}$

Iinguae formis (Evans and

Shumard) -.............

Annmin of. A. tellinolides Morton

$\frac{\text { Lucina subundata Ha1l and Meck }}{\mathrm{sp}}$

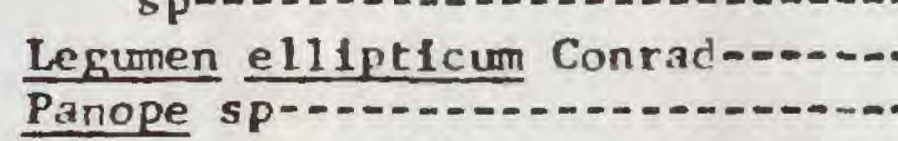

Panope sp-

inna sp-

Pecten (Syncyclonema) sp-....... GASTROTODS

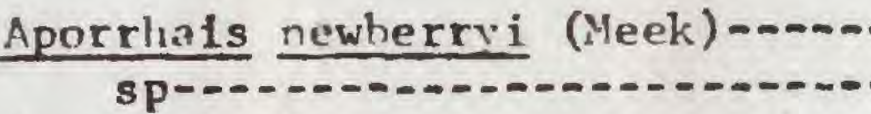

Cryptorhytis sp--

Ellipsoscapha sp--...............

*Acirsa (Picsioacirsa) cf. A.

* Gyrodes Cf. G. americana (Wade)-

* Euspira a rectilabrum (Conrad)

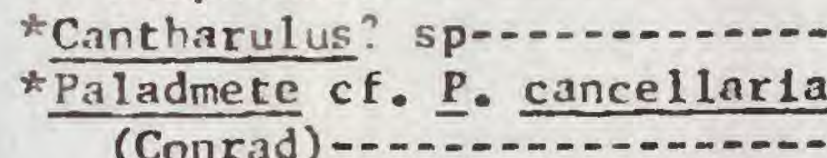

* (Conrad)
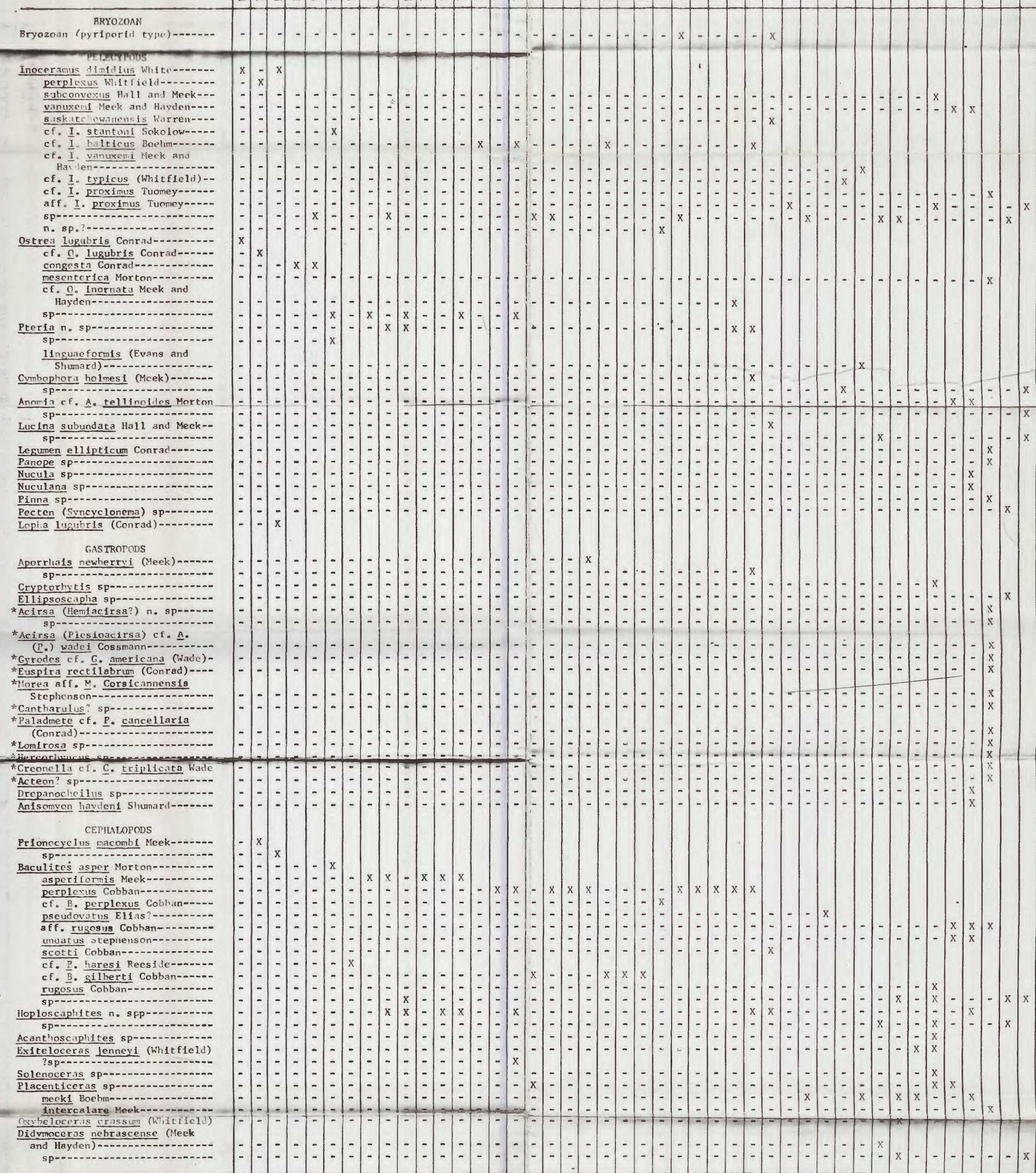

Descriptions of localities

D3173. NWt.NW sec, 15, T. 48 N., R. 7 Wo; from lands 14de debris about $200 \mathrm{ft}$

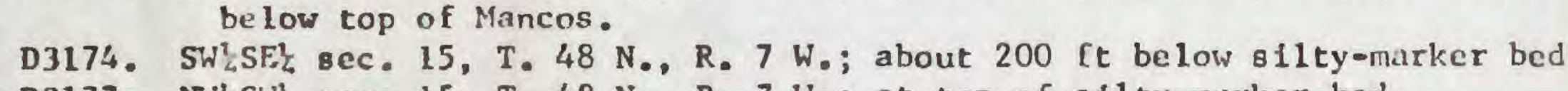

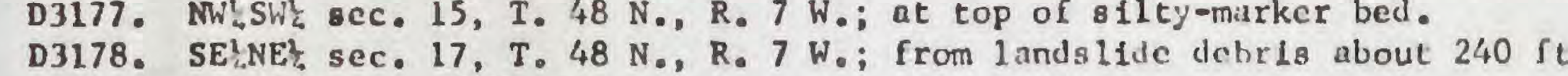

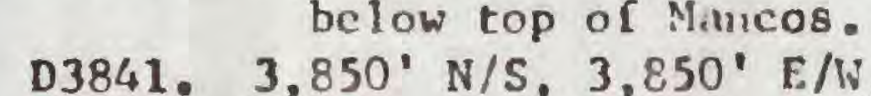

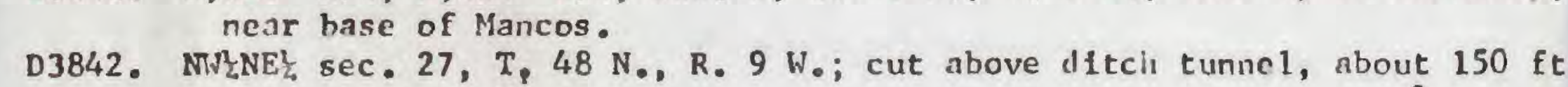

D3843. NWh SEvt sec. 27, T. 47 No, R. 8 W. (approx.); about $450 \mathrm{ft}$ above base of

D3844. Mancos. SEW $^{2}$ sec. 15, T. 48 N., R. 8 W.; about 350 ft be low bentonitic-marker

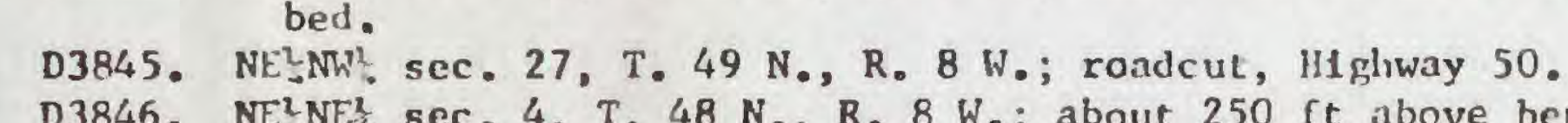

D3846. NEE NF 5 sec. 4, T, 48 N., R. 8 W.; about $250 \mathrm{ft}$ above bentonitic-marker

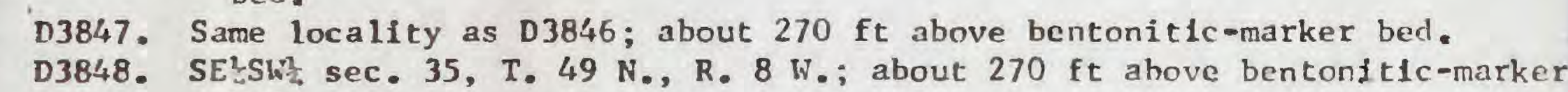

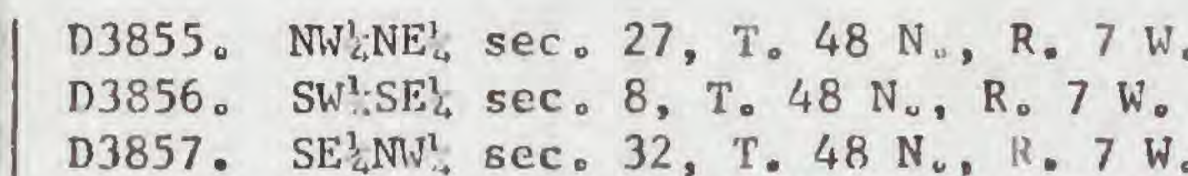

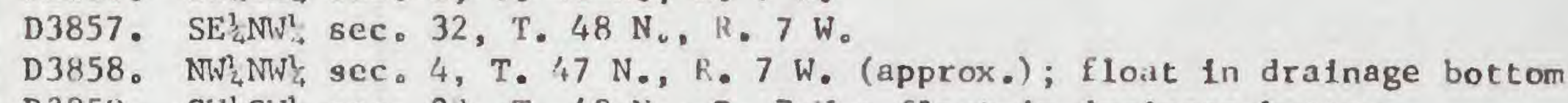

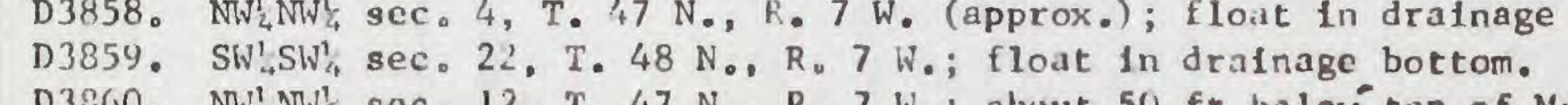

D3860. NW', NW

D3861. NW'.NWW, scc, 17, T. 47 No, R० 7

D 3863 .

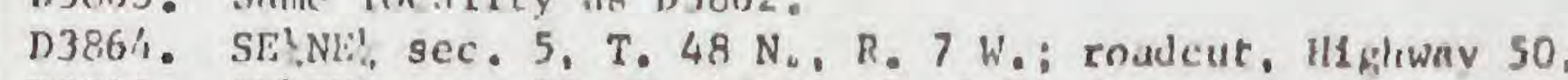

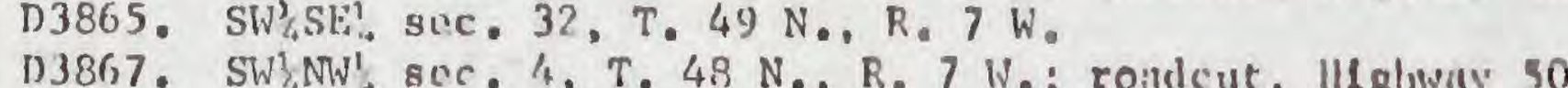

D3868. Sinte locality as D 3867 .

1) 3869 . NE',NW'; sec, 5, T. 48 N., R. 7 W。; roadcut, Higlway 50.

D3871. Same locallty as $03860^{\circ}$

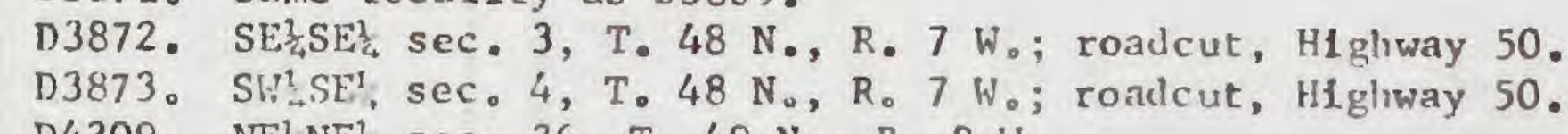

D4310.

D4310. SW'SW's sec. $16, T_{0} 48 \mathrm{~N}_{0}, R_{0} 7 \mathrm{~W}$.

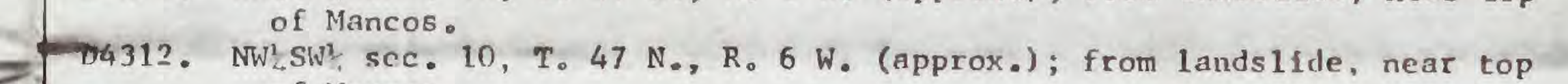

155. Same locality as D3848; about $460 \mathrm{ft}$ above bentonitic-marker bed.

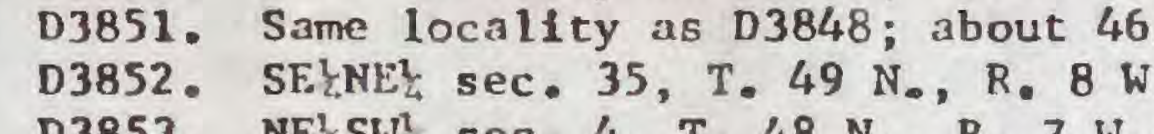

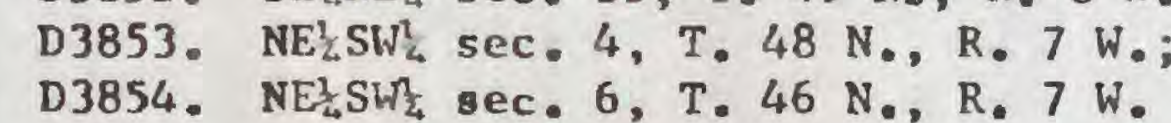

D4313. NE! ME!', sec. 8, T。 47 No, R。 6 W. (approx.)

D4314. N $\mathrm{N}_{2}^{2}$ sec。11, T. $45 \mathrm{~N}_{0}, \mathrm{R}_{0} 7$ W.; roadcuts along Owl Creek road

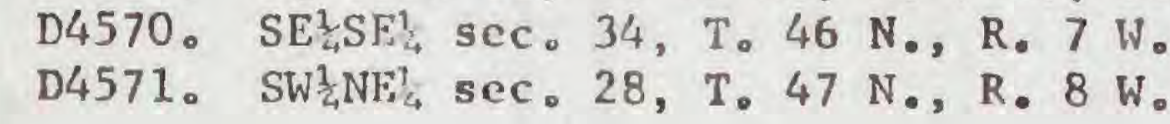


